\title{
Weichselian and Holocene palaeoenvironmental history of the Bol'shoy Lyakhovsky Island, New Siberian Archipelago, Arctic Siberia
}

\author{
ANDREI A. ANDREEV, GUIDO GROSSE, LUTZ SCHIRRMEISTER, TATIANA V. KUZNETSOVA, SVETLANA A. KUZMINA, \\ ANATOLY A. BOBROV, PAVEL E. TARASOV, ELENA Y. NOVENKO, HANNO MEYER, ALEKSANDR Y. DEREVYAGIN, \\ FRANK KIENAST, ANNA BRYANTSEVA AND VIKTOR V. KUNITSKY
}

\section{BOREAS}

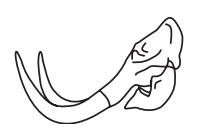

Andreev, A. A., Grosse, G., Schirrmeister, L., Kuznetsova, T. V., Kuzmina, S. A., Bobrov, A. A., Tarasov, P. E., Novenko, E. Y., Meyer, H., Derevyagin, A. Y., Kienast, F., Bryantseva, A. \& Kunitsky, V. V.: Weichselian and Holocene palaeoenvironmental history of the Bol'shoy Lyakhovsky Island, New Siberian Archipelago, Arctic Siberia. Boreas, 10.1111/j.1502-3885.2008.00039.x. ISSN 0300-9483.

Cryolithological, ground ice and fossil bioindicator (pollen, diatoms, plant macrofossils, rhizopods, insects, mammal bones) records from Bol'shoy Lyakhovsky Island permafrost sequences $\left(73^{\circ} 20^{\prime} \mathrm{N}, 141^{\circ} 30^{\prime} \mathrm{E}\right)$ document the environmental history in the region for the past $c$. $115 \mathrm{kyr}$. Vegetation similar to modern subarctic tundra communities prevailed during the Eemian/Early Weichselian transition with a climate warmer than the present. Sparse tundra-like vegetation and harsher climate conditions were predominant during the Early Weichselian. The Middle Weichselian deposits contain peat and peaty soil horizons with bioindicators documenting climate amelioration. Although dwarf willows grew in more protected places, tundra and steppe vegetation prevailed. Climate conditions became colder and drier $c .30 \mathrm{kyr}$ BP. No sediments dated between $c .28 .5$ and $12.05{ }^{14} \mathrm{C} \mathrm{kyr} \mathrm{BP}$ were found, which may reflect active erosion during that time. Herb and shrubby vegetation were predominant 11.6-11.3 ${ }^{14} \mathrm{C}$ kyr BP. Summer temperatures were $c .4{ }^{\circ} \mathrm{C}$ higher than today. Typical arctic environments prevailed around $10.5^{14} \mathrm{C}$ kyr BP. Shrub alder and dwarf birch tundra were predominant between c. 9 and $7.6 \mathrm{kyr} \mathrm{BP}$. Reconstructed summer temperatures were at least $4{ }^{\circ} \mathrm{C}$ higher than present. However, insect remains reflect that steppe-like habitats existed until c. $8 \mathrm{kyr}$ BP. After $7.6 \mathrm{kyr}$ BP, shrubs gradually disappeared and the vegetation cover became similar to that of modern tundra. Pollen and beetles indicate a severe arctic environment $c .3 .7 \mathrm{kyr}$ BP. However, Betula nana, absent on the island today, was still present. Together with our previous study on Bol'shoy Lyakhovsky Island covering the period between about 200 and $115 \mathrm{kyr}$, a comprehensive terrestrial palaeoenvironmental data set from this area in western Beringia is now available for the past two glacial-interglacial cycles.

Andrei A. Andreev (e-mail: andrei.andreev@awi.de),Lutz Schirrmeister and Hanno Meyer, Alfred Wegener Institute for Polar and Marine Research, Research Unit Potsdam, Telegrafenberg A43, D-14473 Potsdam, Germany; Guido Grosse, Geophysical Institute, University of Alaska Fairbanks, 903 Koyukuk Drive, Fairbanks, AK 99775 , USA; Tatiana V. Kuznetsova, Aleksandr Y. Derevyagin and Anna Bryantseva, Faculty of Geology, Moscow State University, Vorobievy Gory, 119992 Moscow, Russia; Svetlana A. Kuzmina, Palaeontological Institute, RAS Profsoyuznaya 123, 117997 Moscow, Russia and Department of Earth and Atmospheric Sciences University of Alberta, Edmonton, Canada, T6G 2E3; Anatoly A. Bobrov, Faculty of Soil Science Moscow State University, Vorobievy Gory, 119992 Moscow, Russia; Pavel E. Tarasov, Institute for Geological Sciences/Palaeontology, Free University Berlin, Malteserstr. 74-100, D-12249 Berlin, Germany; Elena Y. Novenko, Institute of Geography, RAS, Staromonetny 29. 109017 Moscow, Russia; Viktor V. Kunitsky, Permafrost Institute, Siberian Branch Russian Academy of Science, 677010 Yakutsk, Russia; Frank Kienast, Research Institute and Museum for Natural History, Senckenberg Research Station for Quaternary Palaeontology Weimar, Am Jakobskirchhof 4, 99423 Weimar, Germany; received 28th November 2007, accepted 22nd May 2008.

The importance of understanding and predicting the environmental dynamics of the high latitudes is underlined by global climate models predicting a proportionally stronger increase in air temperatures for the Arctic over upcoming decades (ACIA 2005). To assess such dynamics and the manifold global impacts on various time scales, a sound knowledge of the high Arctic past environments is necessary. Glacial or lacustrine records are widely used to reconstruct Quaternary Arctic palaeoenvironments, but the vast regions of the NE Siberian lowlands are still poorly investigated because of a lack of such long-ranging archives. During the late Quaternary, this region was part of Beringia - the largely unglaciated landmass stretching from NE Siberia to Alaska. Thick permafrost deposits that accumulated in the western Beringian lowlands are excellent pa- laeoecological archives and in recent years have been used increasingly in palaeoecological studies (e.g. Andreev et al. 2002a, 2004a; Schirrmeister et al. 2002a, 2003; Ilyashuk et al. 2006; Kienast et al. 2007 and references therein). Detailed investigations of the late Quaternary palaeoenvironment of western Beringia not only complement the understanding of Beringia ecosystems but also deliver highly desirable data on the past environmental dynamics in a poorly studied part of the Arctic.

Since its discovery in the 18th century, Bol'shoy Lyakhovsky Island $\left(73^{\circ} 20^{\prime} \mathrm{N}, 141^{\circ} 30^{\prime} \mathrm{E}\right.$; Fig. 1), situated in the western part of Beringia, has been known for its abundance of fossil mammal bones. Almost 2000 bones were collected during the New Siberian Islands Expedition of 1886 (Bunge 1887; von Toll 1897). Many species 


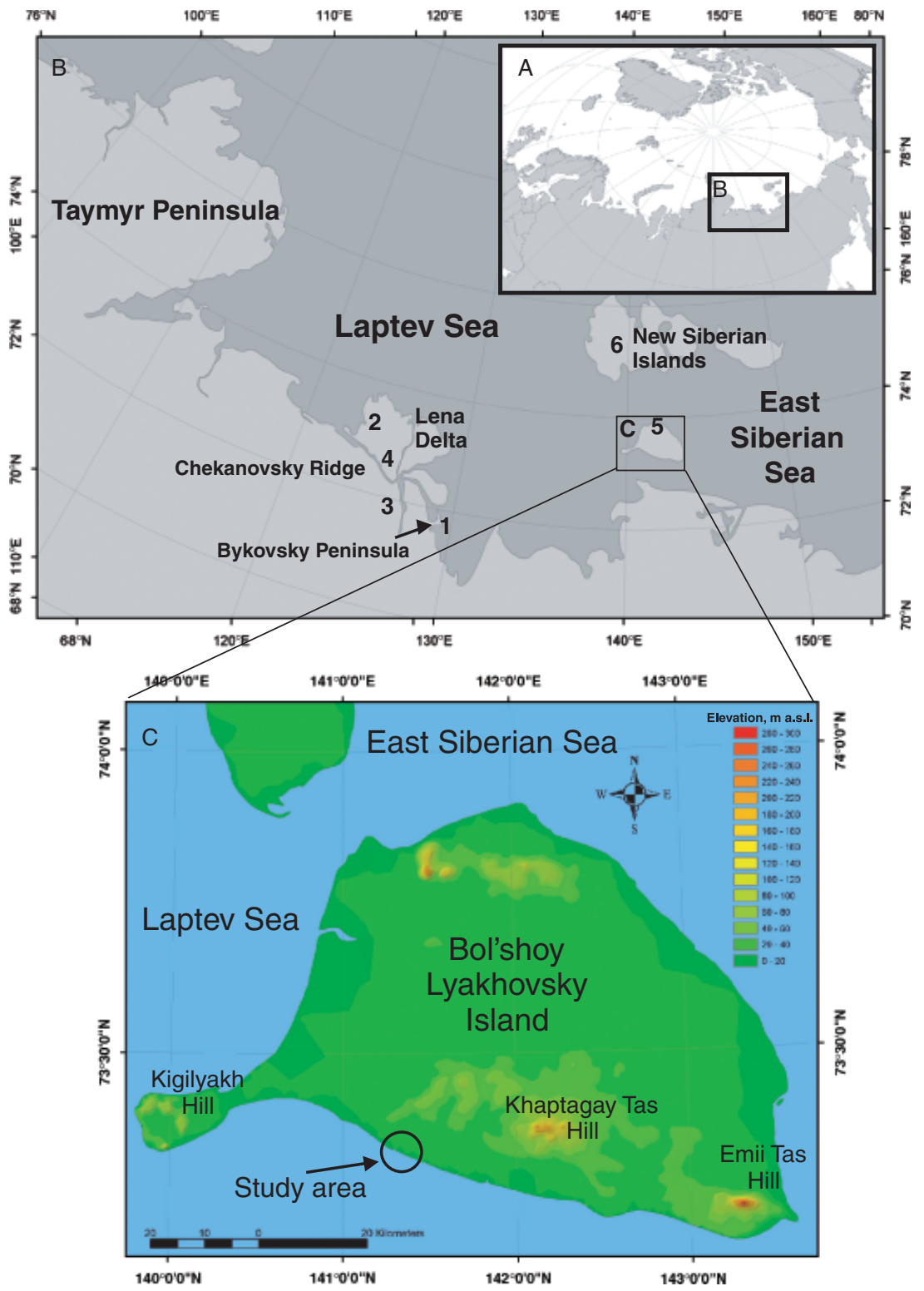

Fig. 1. A. Map of the Arctic. B. Map of the Laptev Sea-Bol'shoy Lyakhovsky Island region. Study sites mentioned in the article: 1 = Bykovsky Peninsula (Andreev et al. 2002a; Schirrmeister et al. 2002b); 2 = Nikolay Lake (Andreev et al. 2004b); 3 = Dolgoe Lake (Pisaric et al. 2001); 4 = Kurungnakh Island, Buor-Khaya section (Schirrmeister et al. 2003); 5 = Levaya Kutta River (Ukraintseva et al. 1989); 6 = Kotelny Island (Makeyev et al. 2003). C. Study area around Zimov'e River on the Bol'shoy Lyakhovsky Island. of fossil mammals, such as saiga antelope, large lion-like panther, woolly rhinoceros and others previously not known in the Arctic, were discovered on the island (Chersky 1891; Kuznetsova et al. 2004), which subsequently became one of the most important Pleistocene mammal sites in Siberia. The deposits of the south coast of Bol'shoy Lyakhovsky Island were first studied in the 19th century (Bunge 1887; von Toll 1897). However, detailed geocryological and palaeoenvironmental studies began much later (Romanovskii 1958a-c; Pirumova 1968; Igarashi et al. 1995; Nagaoka et al. 1995; Arkhangelov et al. 1996; Kunitsky 1998).

In continuation of our studies of the island's preWeichselian environments (Schirrmeister et al. 2002a; Andreev et al. 2004a; Ilyashuk et al. 2006; Kienast et al. 2007), this article presents new radiocarbon and infrared stimulated luminescence (IRSL) dated records doc- umenting the environmental changes in this region since the Early Weichselian to Holocene. We relate these records to both the Siberian and Eurasian Quaternary stratigraphy as well as the marine isotope stages (MIS) as an overarching chronological framework (Table 1). Our approach is based on a number of proxies, including cryolithological structure of the sediments, hydrochemistry of ground ice and fossil bioindicators (pollen, diatoms, plant remains, rhizopods, insects, mammal bones).

Within the joint German-Russian project 'System Laptev Sea', the late Quaternary terrestrial palaeoenvironment of other locations in the Laptev Sea region has already been accessed with comparable comprehensive and multidisciplinary studies (e.g. Andreev et al. 2002a, b, 2004a, b; Meyer et al. 2002a, b; Schirrmeister et al. 2002a-c, 2003; Kienast et al. 2005, 2008; Sher et al. 
Table 1. Correlation of the Pleistocene regional stratigraphic schemes used in the article (based on Astakhov 2001, 2004, 2006; Anderson \& Lozhkin 2001; Svendsen et al. 2004; Arkhipov et al. 2005; Lambeck et al. 2006; Lozhkin et al. 2007).

\begin{tabular}{|c|c|c|c|c|}
\hline Ages (kyr) & West European & Siberian & North American & Marine Isotope Stages \\
\hline c. $30-10.5$ & Late Weichselian & Sartan & Late Wisconsinan & MIS2 \\
\hline c. $50-30$ & Middle Weichselian & Karginsky & Middle Wisconsinan & MIS3/MIS4 \\
\hline c. $110-50$ & Early Weichselian & Ermakovo, Zyryan & Early Wisconsinan & MIS4/MIS5a-d \\
\hline c. $130-115$ & Eemian & Kazantsevo & Sangamonan & MIS5e \\
\hline c. $200-130$ & Saalian & Tazovsky & Illinoian & MIS6 \\
\hline
\end{tabular}

2005; Ilyashuk et al. 2006; Kuzmina \& Sher 2006; Grosse et al. 2007). Based on these efforts, we provide an additional piece of the palaeoenvironmental record - from a still poorly understood part of the Laptev Sea region - that is of great importance for our understanding of the late Quaternary history of western Beringia. The key goals for this study are therefore the establishment of a geochronology for the late Quaternary deposits of Bol'shoy Lyakhovsky, the extraction and analysis of a wide variety of palaeo-ecological indicators from permafrost deposits and the characterization of environmental changes and their broader relevance during the late Quaternary based on our palaeo-ecological indicators and geochronology.

\section{Regional setting and geological situation}

Bol'shoy Lyakhovsky Island is the southernmost island of the New Siberian Archipelago (Fig. 1). It is located east of the recently active Gackel-Ust Lena Rift Zone, which represents the boundary between the North American and the Eurasian lithosphere plates. The island has a few heavily weathered bedrock elevations up to about $300 \mathrm{~m}$ a.s.l., but consists otherwise of a generally smooth relief intersected by thermokarst basins and thermo-erosional valleys. Large parts of its southern coast consist of exposures formed by coastal abrasion of $30-40 \mathrm{~m}$ thick Quaternary permafrost deposits. A number of thermo-erosional cirques (TZ) were formed by melting of the ice-rich sediments, resulting in retrogressive coastal cliffs. According to reconstructions of the Eurasian glaciations (Hubberten et al. 2004 and references therein), as well as our data (Andreev et al. 2004a; and this article), the region has remained unglaciated at least since the late Saalian. These conditions preserved local permafrost deposits and hence provide palaeoenvironmental records covering a time period of more than $200 \mathrm{kyr}$. Neotectonic activity in the study area has been important for the general geological situation and sedimentary processes. Bol'shoy Lyakhovsky Island is situated not far east of the Laptev Rift, protruding onto the Laptev Shelf. Generally, the New Siberian Islands consist of horst and graben structures influenced by the rift system. Many works describe the impact of neotectonics on local geology (e.g. Drachev et al. 1998), the palaeo- environment during the late Quaternary (Kienast et al. 2008) and permafrost degradation and shelf inundation during the early Holocene (Romanovskii et al. 2004).

In summer 1999, we carried out a multidisciplinary study of the sediment sequences (Fig. 2) along a coastal bluff stretching several kilometres to the east and west of the Zimov'e River mouth (Schirrmeister et al. 2000). The studied exposures in the bluff were labelled according to their position relative to the Zimov'e River mouth (sections $\mathrm{R}$ and $\mathrm{TZ}$ to the west and $\mathrm{L}$ to the east). The hinterland of the study area is formed by gradually sloping terrain intersected by rivers and thermo-erosional valleys. Approximately $26 \mathrm{~km}$ to the NE, bedrock hills up to $200 \mathrm{~m}$ a.s.l. are characterized by cryoplanation terraces important as a source of local sediment (Kunitsky et al. 2002).

In the lower part (up to $15 \mathrm{~m}$ a.s.1.), the studied sequences consist of Saalian Ice Complex (unit I) and floodplain/lacustrine (unit IIa/b) deposits covered by Eemian lacustrine (unit III) and Early Weichselian floodplain (unit IV) deposits (Fig. 2). Detailed descriptions of these sequences and palaeoenvironmental reconstructions have been published by Meyer et al. (2002b), Schirrmeister et al. (2002a), Andreev et al. (2004a), Ilyashuk et al. (2006) and Kienast et al. (2008). This study focuses on post-Eemian palaeoenvironments reconstructed from the late Pleistocene Ice Complex (unit Va) and Holocene deposits (unit VI).

The Ice Complex consists of ice-rich silty fine sand with peaty palaeosol horizons. Large syngenetic ice wedges and high contents of segregated ground ice are also characteristic. The deposits are intersected by deep thermo-erosive valleys and thermokarst depressions that formed due to strong surface subsidence of thawing ice-rich deposits. Subaquatic and subaerial deposits accumulated in these depressions during the Holocene. Younger epigenetic ice wedges are common in these deposits.

\section{Methods}

This article is the continuation of our studies of preWeichselian environments on the island, and all methods applied are the same as used in Andreev et al. (2004a). We do not therefore describe them again, but instead refer the reader to previous publications for 


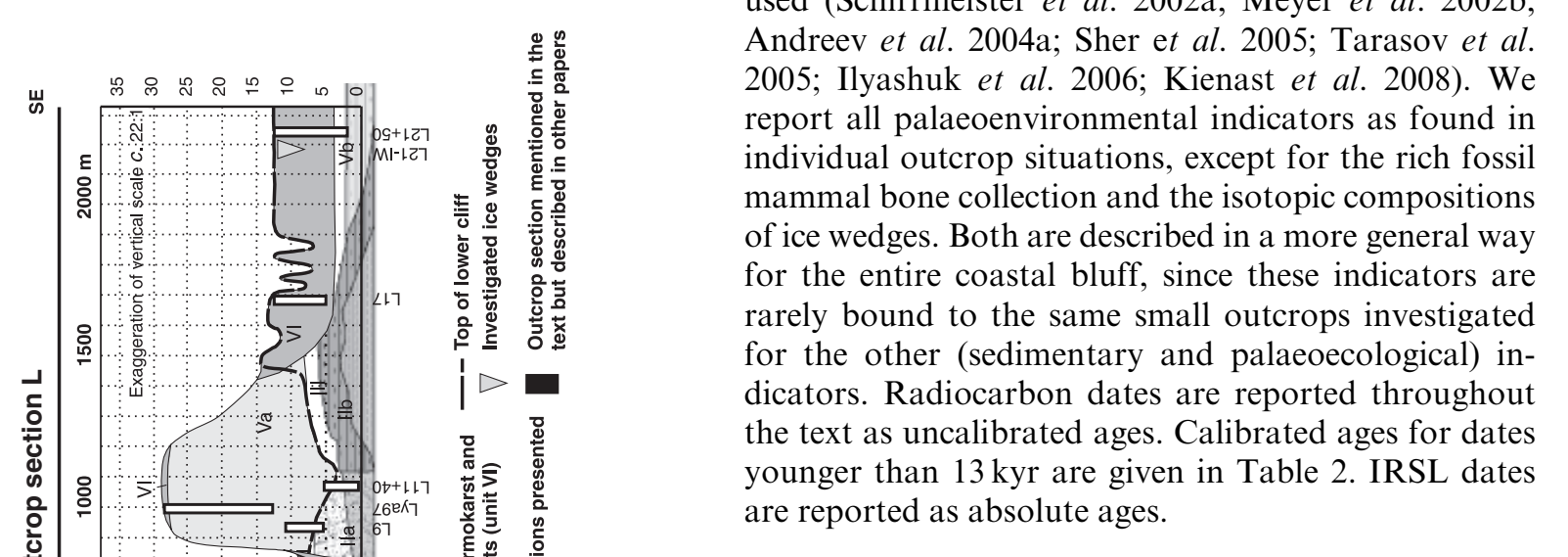

\section{Results}

\section{Sections west of the Zimov'e River}

Section R23+40. - This section is situated $2.34 \mathrm{~km}$ west of the Zimov'e River mouth (Fig. 2). The lower $300 \mathrm{~cm}$ consists of laminated, graded and ripple bedded sandy to clayish lacustrine sediments (unit IIb/unit III) and contains shells of freshwater Pissidium sp. The upper horizons of peaty-sandy bedding belong to unit Va. The pollen spectra were divided into two pollen zones (PZ) dominated by Cyperaceae and Poaceae (Fig. 3). The presence of Alnus fruticosa, Betula sect. Nanae and Ericales pollen is characteristic of the PZ-I. PZ-II is notable for large amounts of Equisetum spores. There are three infinite ${ }^{14} \mathrm{C}$ dates from the section (Table 2). Two thermoluminescence (TL) ages $(114 \pm 28(200 \mathrm{~cm}$ a.s.1.) and $96 \pm 26(500 \mathrm{~cm}$ a.s.1.)) of samples collected at the section during previous studies (Andreev et al. 2004a) and the PZ-I pollen assemblage indicate a late Eemian/Early Weichselian sedimentation for the section.

Sections of the third thermo-erosion cirque (3TZ). - Three subprofiles (Fig. 4A-C) studied between 2.3 and $2.5 \mathrm{~km}$ east of the Zimov'e River belong to the Ice Complex (unit Va) and consist of silty fine sand alternating with peaty palaeosols. The exposure is characterized by $2-4 \mathrm{~m}$ wide ice wedges enclosing the intra-polygonal sediment accumulations. The ice-rich (gravimetric ice content 60-160 wt $\%$ ) sediments have cryostructure saturated by lens-like reticulated and small ice bands. Five ${ }^{14} \mathrm{C}$ ages (Table 2) suggest that the deposits were accumulated during the Early/Middle Weichselian.

PZ-I of the section 3TZ1 (Fig. 4A) is characterized by relatively low pollen concentration and dominated by Poaceae, Cyperaceae and Caryophyllaceae. The lowermost spectrum (PZ-Ia) contains large amounts of reworked Pinaceae and remains of Pediastrum colonies. The pollen concentration is much higher in PZ-II. The PZ-IIa spectra consist mostly of Cyperaceae and Poaceae, with 
Table 2. AMS and conventional (*) radiocarbon dates from the upper units of the Zimov'e River study site. Calibrated ages according to CALIB rev. 4.3 (Stuiver et al. 1998).

\begin{tabular}{|c|c|c|c|c|c|}
\hline Sample ID & $\begin{array}{l}\text { Elevation } \\
\text { (m a.s.l.) }\end{array}$ & Dated material & Age (yr BP) & $\begin{array}{l}\text { Age (cal. yr } \\
\text { BP } 2 \sigma 95 \%)\end{array}$ & Lab. no \\
\hline $\mathrm{R} 23+40-\mathrm{S}-8$ & 5.75 & Peat & $48340+2860 /-2110$ & & KIA12543 \\
\hline R23+40-S-5 & 4.75 & Plant remains & $>52020$ & & KIA12542 \\
\hline $\mathrm{R} 23+40-\mathrm{S}-2$ & 2.75 & Plant remains & $>51640$ & & KIA12541 \\
\hline 3TZ1-S-7 & 17.8 & Plant remains & $>40880$ & & KIA25710 \\
\hline 3TZ1-S-5 & 17.3 & Twigs & $54050+3130 /-2250$ & & KIA9889 \\
\hline 3TZ2-S-8 & 19.3 & Plant remains & $>43690$ & & KIA25708 \\
\hline 3TZ2-S-1 & 16.6 & Plant remains & $>45940$ & & KIA25709 \\
\hline 3TZ5-S-3 & 16.6 & Plant remains & $48560+1670 /-1100$ & & KIA9890 \\
\hline $\mathrm{R} 18+50-\mathrm{S}-15$ & 16.8 & Plant remains & $44660+2220 /-1740$ & & KIA12539 \\
\hline $\mathrm{R} 18+50-\mathrm{S}-12$ & 15,0 & Plant remains & $47940+5150 /-3110$ & & KIA12538 \\
\hline $\mathrm{R} 18+50-\mathrm{S}-8$ & 13.5 & Plant remains & $>44160$ & & KIA 12537 \\
\hline R18-OS-41 & 17.1 & Plant remains & $>51820$ & & KIA32442 \\
\hline R18-OS-48 & 16.8 & Plant remains & $34480+870 /-780$ & & KIA32443 \\
\hline 2TZ1-S-4 & 21.35 & Plant remains & $>36140$ & & KIA25711 \\
\hline 2TZ1-S-1 & 20.3 & Plant remains & $51950+2310 /-1790$ & & KIA11444 \\
\hline 2TZ3-S-3 & 24.4 & Plant remains & $52900+4570 /-2890$ & & KIA11445 \\
\hline R6-OS-16 & 4.3 & Plant remains & $>50610$ & & KIA32441 \\
\hline 1TZ1-S-5 & 23.4 & Peat & $35680+400 /-390$ & & KIA12548 \\
\hline 1TZ1-S-3 & 22.35 & Peat & $41150+2390 /-1840$ & & KIA25707 \\
\hline 1TZ3-S-1 & 13.0 & Plant detritus & $>43990$ & & KIA12549 \\
\hline R4-OS-35 & 21.4 & Plant remains & $40160+670 /-620$ & & KIA32444 \\
\hline R33-A1-S-22 & 14.3 & Peat & $3705 \pm 45$ & 4155-3894 & $\mathrm{KI}-4849 *$ \\
\hline R33-A1-S-23 & 14.1 & Peat & $10570 \pm 110$ & $12955-11965$ & $\mathrm{KI}-4850 *$ \\
\hline R33-A1-S-20 & 13.7 & Twigs & $7960 \pm 50$ & $9010-9704$ & KIA11476 \\
\hline R33-A1-S-17 & 12.0 & Moss peat & $8410 \pm 70$ & $9533-9625$ & KIA11448 \\
\hline R33-A1-S-12a & 10.12 & Gastropod & $12485 \pm 60$ & $14940-14215$ & KIA11447 \\
\hline R33-A1-S-9a & 9.52 & Plant detritus & $12085 \pm 50$ & $15356-14645$ & KIA9894 \\
\hline R33-A1-S-6 & 8.5 & Wood & $8170 \pm 105$ & $9425-8815$ & $\mathrm{KI}-4847 *$ \\
\hline R33-A1-S-6 & 8.5 & Wood fragment & $8310 \pm 40$ & $9470-9447$ & KIA12552 \\
\hline R33-A1-S-5 & 8.2 & Plant detritus & $9320 \pm 60$ & $10688-10588$ & KIA12551 \\
\hline R33-A1-S-3 & 8.0 & Peat & $45240+3710 /-2530$ & & KIA 12550 \\
\hline R33-A1-S-1 & 7.0 & Small plant remains & $51160+4730 /-2960$ & & KIA11446 \\
\hline R33-A2-2 & 14.0 & Twigs & $8865 \pm 50$ & 10 275-9704 & KIA9893 \\
\hline R33-A2-1 & 13.5 & Twigs & $8350 \pm 50$ & $9490-9252$ & KIA9892 \\
\hline R24-Ho & IC top & Alder wood & $9060 \pm 45$ & $10365-10155$ & $\mathrm{KI}-4855 *$ \\
\hline $\mathrm{L} 21+50-\mathrm{S}-14$ & $10.4^{*}$ & Peat & $8400 \pm 60$ & $9535-9155$ & KI-4853* \\
\hline $\mathrm{L} 21+50-\mathrm{S}-12$ & 9.5 & Twigs & $8940 \pm 45$ & $10214-10095$ & KIA11477 \\
\hline $\mathrm{L} 21+50-\mathrm{S}-11$ & 8.5 & Bulk sediment & $8770 \pm 70$ & $10150-10050$ & KIA12547 \\
\hline $\mathrm{L} 21+50-\mathrm{S}-10$ & 8.2 & Plant remains & $38080+2270 /-1770$ & & KIA25705 \\
\hline $\mathrm{L} 21+50-\mathrm{S}-9$ & 7.5 & Plant remains & $10500 \pm 50$ & $12874-12289$ & KIA25704 \\
\hline $\mathrm{L} 21+50-\mathrm{S}-7$ & 6.2 & Twigs & $11325 \pm 50$ & $13779-13675$ & KIA11451 \\
\hline $\mathrm{L} 21+50-\mathrm{S}-5$ & 5.0 & Peat and twigs & $11570 \pm 90$ & $13845-13175$ & $\mathrm{KI}-4851 *$ \\
\hline $\mathrm{L} 21+50-\mathrm{S}-4$ & 4.3 & Bulk sediment & $33020+290 /-280$ & & KIA12546 \\
\hline $\mathrm{L} 21+50-\mathrm{S}-4$ & 4.3 & Plant detritus & $39960+2640 /-1980$ & & KIA12554 \\
\hline $\mathrm{L} 21+50-\mathrm{S}-1$ & 2.5 & Plant remains & $49840+2700 /-2020$ & & KIA11450 \\
\hline L17-OS-63 & 13.5 & Peat & $3700 \pm 30$ & $4148-4111$ & KIA12545 \\
\hline L17-OS-62 & 8.5 & Wood & $8020 \pm 35$ & $9014-8926$ & KIA12544 \\
\hline \multicolumn{6}{|c|}{ AMS radiocarbon dates from ice wedges. } \\
\hline LYA-L6-14C-1 & 9 & Plant remains & $39730+1290 /-1110$ & & KIA14733 \\
\hline TZ2-4-14C-1 & 15.8 & Salix leaves & $34970+2080 /-1650$ & & KIA9886 \\
\hline TZ2-2-I29/30 & 8.2 & $\begin{array}{l}\text { Plant remains near ice } \\
\text { wedge }\end{array}$ & $3435 \pm 30$ & $3826-3791$ & KIA9885 \\
\hline L21-1-Be-9 & 9.5 & Plant remains & $855 \pm 50$ & $1035-1144$ & KIA9883 \\
\hline L21-1-Be-5 & 9.5 & Plant remains & $135 \pm 30$ & $1669-1780$ & KIA9882 \\
\hline LYA-R9-1-I1 & 9 & Lemming dropping & $49200+2400 /-1850$ & & KIA9881 \\
\hline
\end{tabular}

few Caryophyllaceae. PZ-IIb is dominated mostly by Poaceae and contains larger amounts of Pediastrum remains and reworked Pinaceae. Relatively rich rhizopod palaeocoenoses found in both peat layers (Appendix 1) point to mesotrophic soil conditions. Hydrophilic Cen- tropyxis elongata and Difflugia lucida reflect rather wet habitats. The presence of Arcella arenaria v. compressa, Euglypha sp. and changes in the Nebela complex in the upper peat points to more oligotrophic conditions and lower water table. 


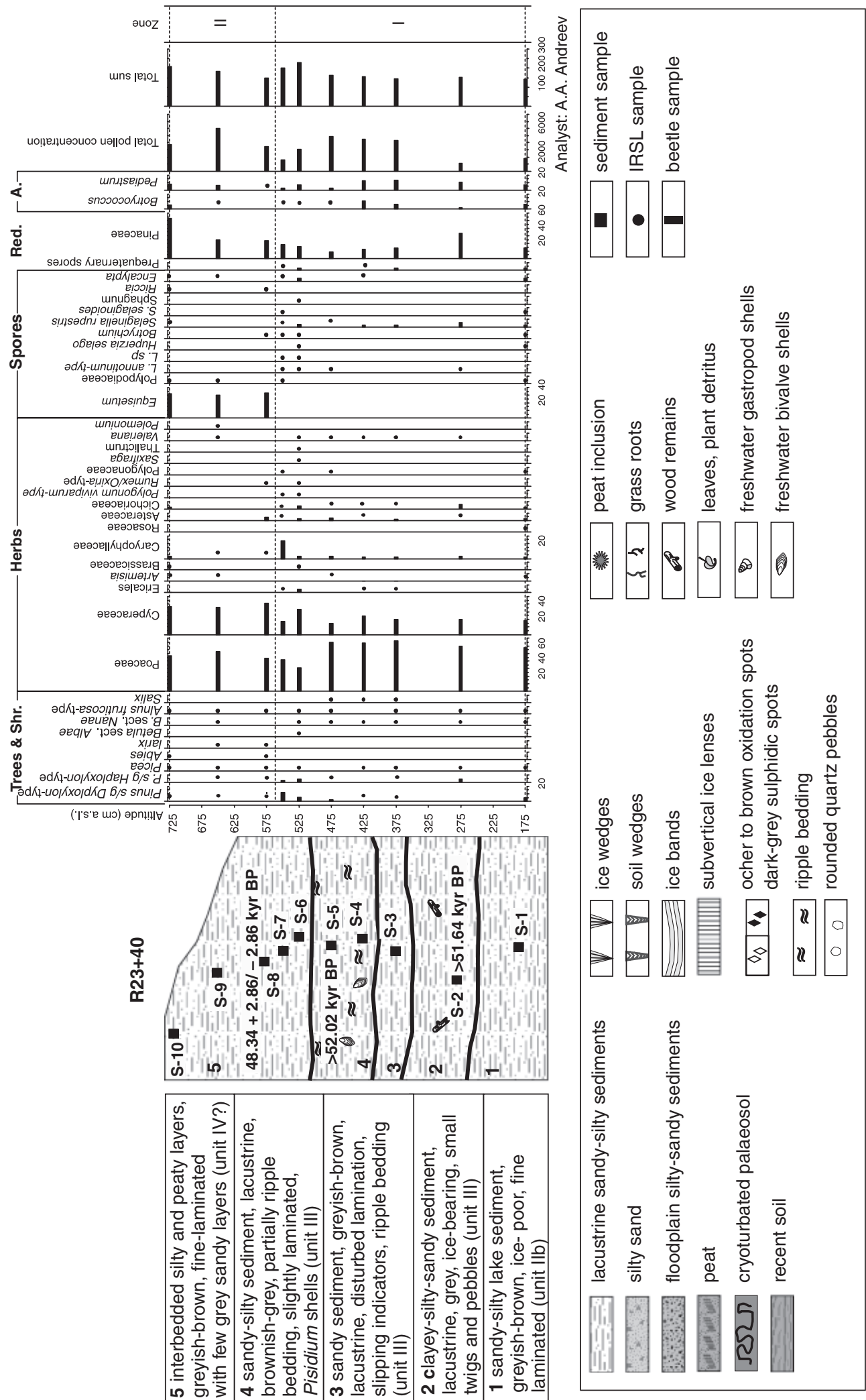



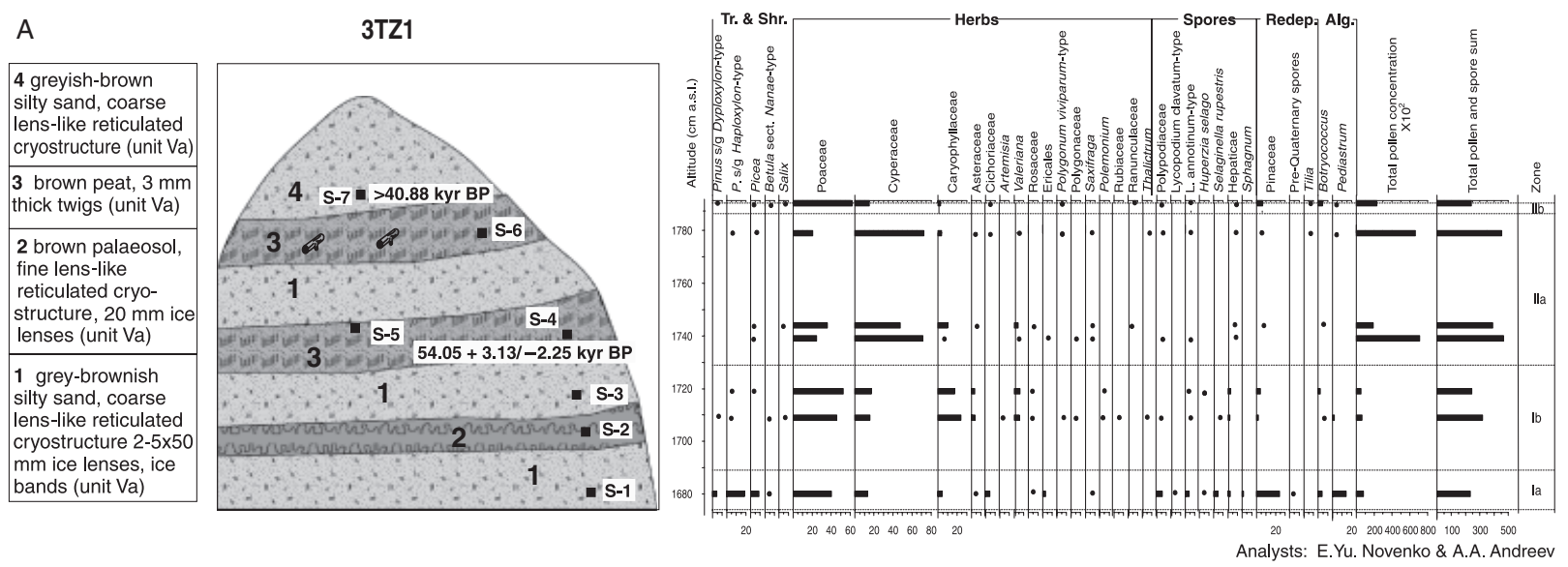

B
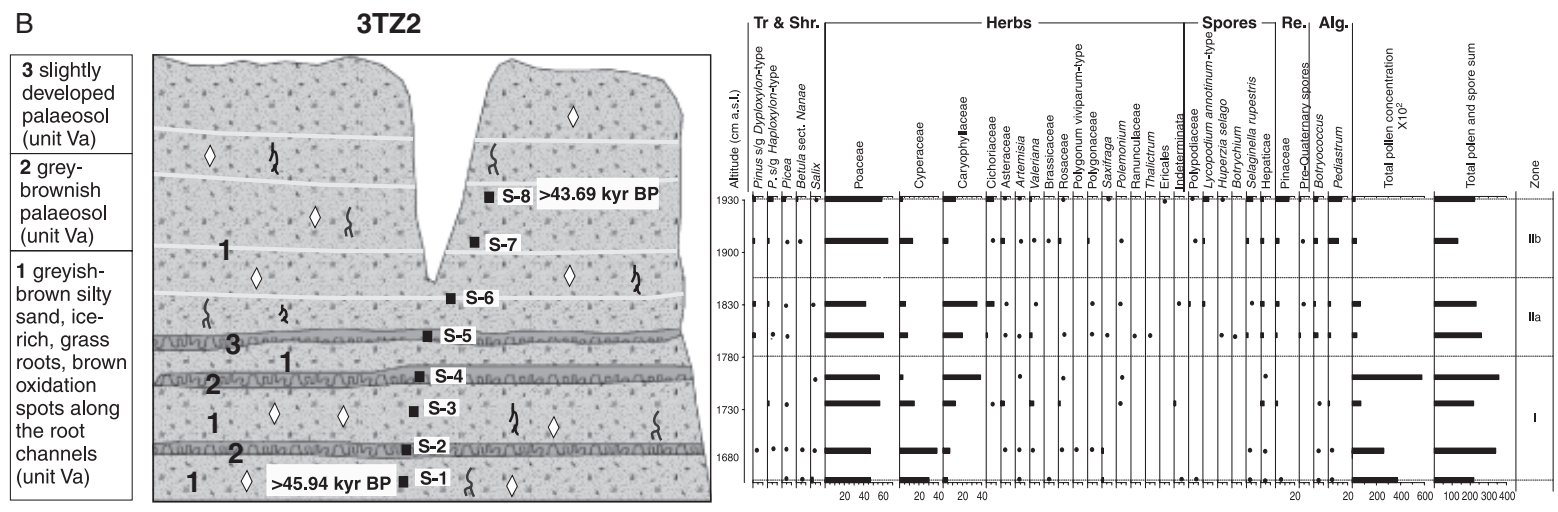

Analysts: E.Yu. Novenko \& A.A. Andreev

C

3 TZ5
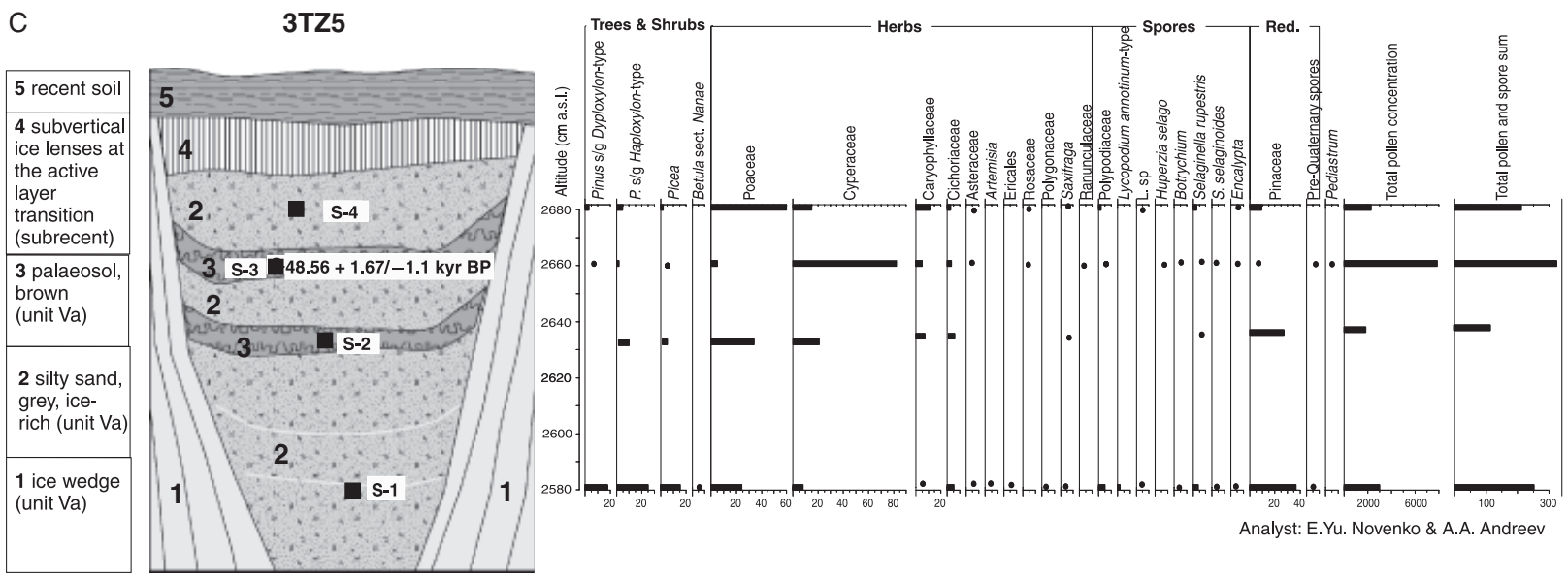

Fig. 4. Profiles, age determinations and pollen data of the Ice Complex within the third thermo-erosional cirque (3TZ). A. Outcrop and pollen percentage diagram of section 3TZ1. B. Outcrop and pollen percentage diagram of 3TZ2 section. C. Outcrop and pollen percentage diagram of section 3TZ5. For legend, see Fig. 3.

The sediments also contain diatom valves (Appendix 2). The lowermost sample is characterized by a relatively low abundance of valves, but high species diversity (mostly benthic, periphytic and littoral taxa). A few reworked valves were also found. The upper samples (with the exception of the uppermost one) contain high amounts of diatoms, but the species diversity is lower. Soil taxa are more abundant in the upper sediments.
Pollen spectra of section 3TZ2 are mostly dominated by Poaceae, Cyperaceae and Caryophyllaceae and can be subdivided into two PZ (Fig. 4B). PZ-I is characterized by a high pollen concentration. The concentration is much lower in PZ-II. PZ-IIb is distinguishable from PZ-IIa by a lower content of Caryophyllaceae pollen and higher presence of Pediastrum colonies. Eurybiotic rhizopods (Appendix 1) were found within the second palaeosol. 
The pollen spectra of section 3TZ5 (Fig. 4C) are dominated mostly by Poaceae, Cyperaceae, Caryophyllaceae and Cichoriaceae, as well as by large amounts of reworked Pinaceae. Rhizopod palaeocoenoses show a low diversity of species (Appendix 1). Soil Centropyxis species (mostly minor and minima forms) point to the xerophytic soil environment.

Sections of the second thermo-cirque (2TZ). - The 2TZ subprofiles situated $1.7-1.9 \mathrm{~km}$ west of the Zimov'e River mouth (Fig. 2) consist of ice-rich (40-160 wt\%) silty fine sand containing numerous grass roots interbedded with peaty palaeosols (Fig. 6). The cryostructures are lens-like reticulated and banded. Three ${ }^{14} \mathrm{C}$ dates (Table 2) point to the Middle Weichselian age of the sediments.

Pollen spectra of section 2TZ1 are dominated by Poaceae, Cyperaceae and Caryophyllaceae (Fig. 6A). PZ-I is notable for large amounts of reworked Pinaceae and relatively low pollen concentration. The concentration is much higher in PZ-II containing few reworked Pinaceae.

Profile 2TZ2 was subdivided into two PZ dominated by Poaceae, Caryophyllaceae, Cyperaceae and Cichoriaceae (Fig. 6B). PZ-II is characterized by large amounts of reworked Pinaceae.

A nearby thermokarst mound (an erosional remnant with undisturbed still frozen sediments) was studied for insects (sample B9), pollen and plant remains (sample OS-37). The sediments are quite rich in fossil insects (Appendix 3) with dominating xerophilous tundra taxa $(43 \%)$. However, mesophilous species are also numerous $(38 \%)$. These species are cold adapted and live or could live on the island today. The finding of Notiophilus aquaticus, now living on dry habitats from the deciduous forest to the arctic tundra, is especially notable. This beetle (the most thermophilous from the assemblage) was common in Pleistocene tundra-steppe habitats. Another tundra-steppe indicator is Poecilus nearcticus, a relict Holarctic species found in a few isolated tundra habitats in North America and Siberia (Lindroth 1966; Kiselyov 1981). The sediments also contain numerous remains of arctic pioneer plants (Draba, Minuartia rubella, Papaver sect. Scapiflora), abundant fruits of Potentilla stipularis (a dryness indicator), but few Poaceae remains (Appendix 4). The rarity of grass remains might be a result of taphonomic biases. The pollen spectrum is dominated by Poaceae, Artemisia, Cyperaceae, Brassicaceae and Caryophyllaceae, confirming the tundra-steppe environment reconstructed from beetle and plant remains. Large amounts of Podospora and Sordaria spores (dung-inhabiting fungi) suggest the presence of numerous grazing mammals, such as mammoths, bison and horses.

Another nearby thermokarst mound in the same stratigraphical position was studied for insects (sample B12), pollen (samples OS-46 and OS-48) and plant remains (sample OS-48). The only tundra beetles were found here (Appendix 3). Pollen spectrum OS-46 dominated by Poaceae and Cyperaceae with few Betula sect. Nanae pollen confirms a tundra-like environment, but also reflects the presence of dwarf birch. The macrofossil composition of sample OS-48 resembles sample OS-37, but contains numerous Poaceae remains (Appendix 4). Despite their poor preservation, Festuca, Poa and Elytrigia/Elymus were identified. As well as numerous Potentilla stipularis remains, these indicate a cold and dry environment. Puccinellia sp., an indicator of fluctuating moisture and salt accumulation due to high evaporation, was also found. The pollen spectrum is dominated by Poaceae and Cyperaceae with a few Brassicaceae and Caryophyllaceae confirming cold and dry conditions.

Section R18+50. - This section was located close to the $2 \mathrm{TZ}$, about $1.85 \mathrm{~km}$ west of the Zimov'e River mouth (Fig. 2). The profile consists of ice-rich (45-120 wt $\%$ ) grey fine sand with some small pebbles and two cryoturbated brownish palaeosols (Fig. 5). Depending on the ice content, the cryostructures were either massive or banded. The sediments are bracketed by four ${ }^{14} \mathrm{C}$ dates from this outcrop (Table 2) and underlying deposits, and thus an Early to Middle Weichselian age is indicated. The pollen spectra dominated by Poaceae and Cyperaceae with some Caryophyllaceae and Cichoriaceae contain large amounts of reworked Pinaceae. They can be subdivided into 2 PZ. PZ-II is characterized by a higher presence of green algae colonies.

The upper part of the section was studied for insect and plant remains. Sample B10 contains few insect remains (Appendix 3), but remarkably, Morychus viridis, a good indicator of tundra-steppe environment, has been found there. Samples OS-39, OS-41 and OS-43 were analysed for plant macrofossils (Appendix 4). Their assemblages are mainly composed of arctic pioneer plants (mostly Draba sp.), a few tundra steppe indicators (e.g. Potentilla stipularis) and numerous Poaceae (including Puccinellia sp.). The remains are poorly preserved, thus impeding a more detailed identification of grasses.

Section R6. - Located $0.6 \mathrm{~km}$ west of the Zimov'e River mouth (Fig. 2), this section was composed of loess-like fine-grained sediment (unit IV) and ice-rich deposits of the Ice Complex (unit Va). An infinite ${ }^{14} \mathrm{C}$ date (Table 2) suggests the Early Weichselian age of the sediments.

Samples B3, B5 and B4 from the section (Fig. 7) were studied for insects. The few remains found belong mostly to typical tundra-steppe beetles, some of which are cold-resistant (Appendix 3). Sample OS-16 contains numerous well-preserved flowers, leaf fragments and fruits of Artemisia frigida, Koeleria sp. and Festuca sp. (Appendix 4). The proportion of steppe plants in this 


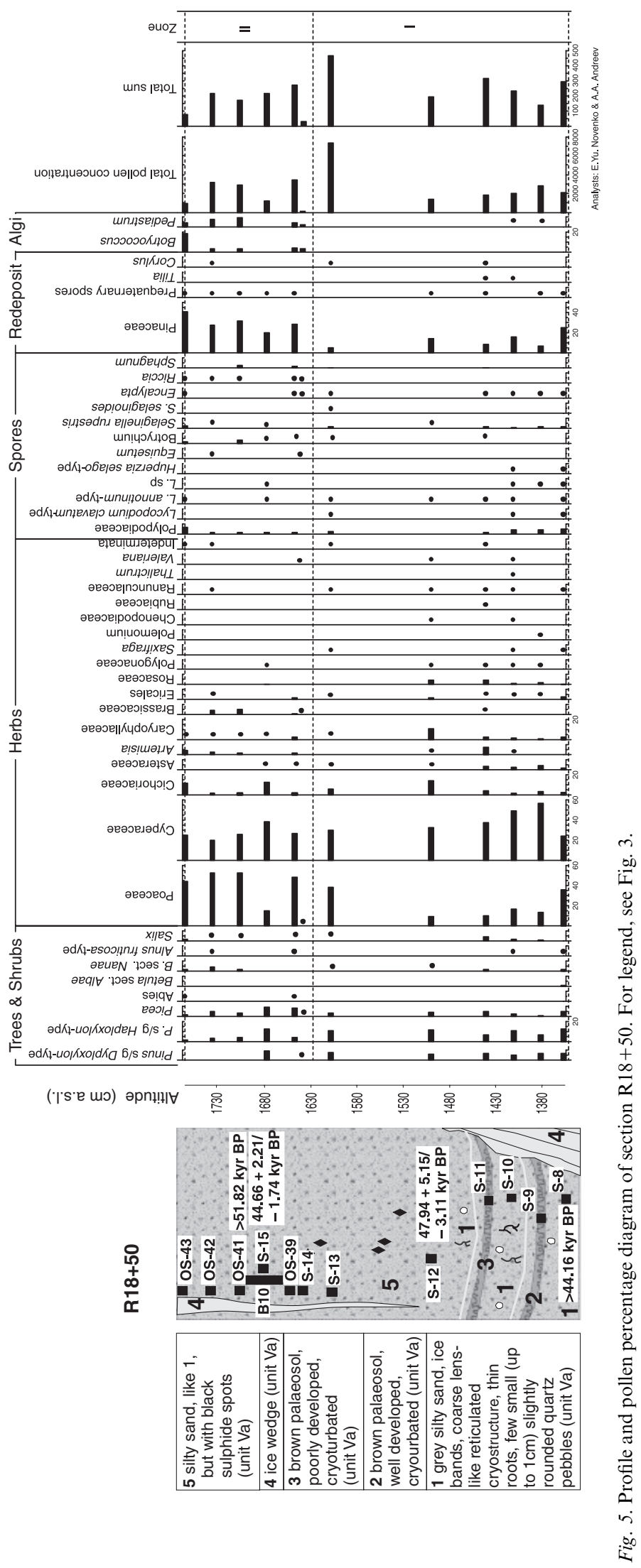


A

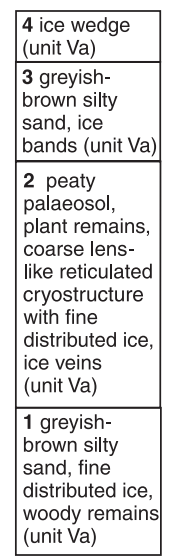

2TZ1

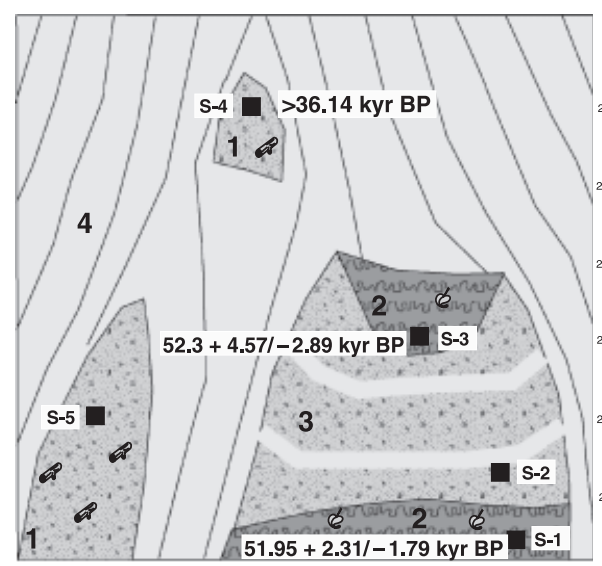

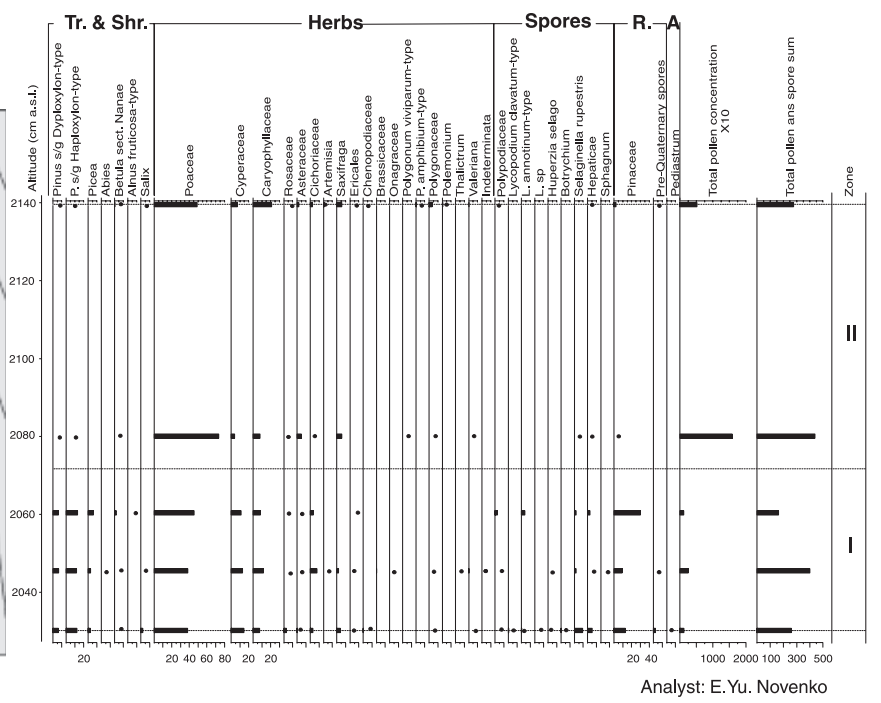

Analyst: E.Yu. Novenko
B

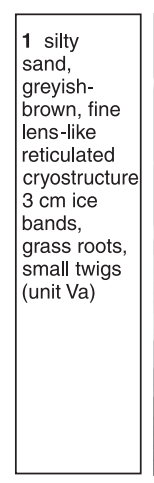

2TZ2

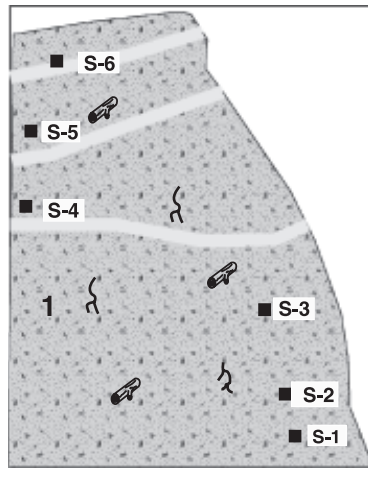

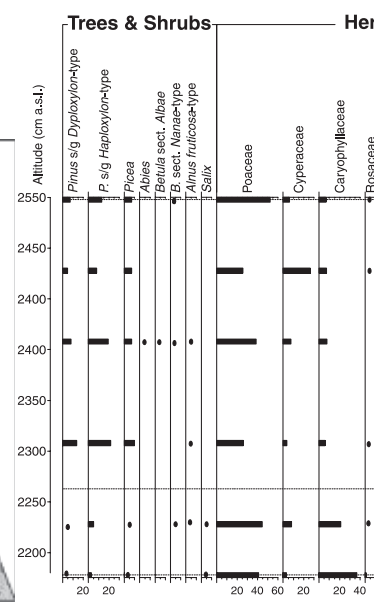

Herbs
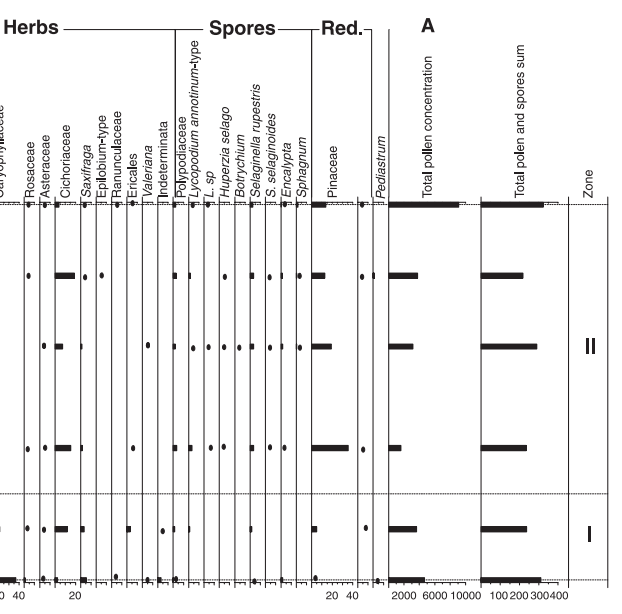

Analyst: E.Yu. Novenko

Fig. 6. Profiles, age determinations and pollen data of the Ice Complex within the second thermo-erosional cirque (2TZ). A. Profile and pollen percentage diagram of section 2TZ1. B. Profile and pollen percentage diagram of section 2TZ2. For legend, see Fig. 3.

assemblage is the highest of all the studied samples, possibly reflecting particular taphonomic conditions. However, the lower number of arctic pioneers, despite an equal sample mass, is not in line with a taphonomic bias. Besides steppe plants indicating dryness, the halophytes Monolepis asiatica and Puccinellia reflect high evaporation. Pollen spectrum of sample OS-20 dominated by Cyperaceae, Poaceae and Artemisia also reflects a steppe-like environment. Samples OS-21 and OS-22 are dominated by Poaceae and Cyperaceae pollen and characterized by large amounts of reworked Pinaceae and low pollen concentration. Sample OS-23 contains very poorly preserved plant remains excluding species identification.

Sections of the first thermo-cirque (1TZ). - Several subprofiles from 1TZ $(0.4-1.0 \mathrm{~km}$ west of the Zimov'e River mouth) were studied. The ice-rich sequences showed lens-like reticulated cryostructures and consist of brownish peaty palaeosols alternating with greyishbrown silty fine sands (Fig. 8).

Pollen spectra of section 1TZ1 can be subdivided into 3 PZ (Fig. 8C). PZ-I is dominated by Poaceae and Cyperaceae. Pollen concentration is high, but lower in PZ-II dominated by Poaceae, Cyperaceae and Caryophyllaceae. Reworked Pinaceae are also present. A higher pollen concentration is a characteristic of PZIII. According to ${ }^{14} \mathrm{C}$ dates (Table 2), the deposits were accumulated during the Middle Weichselian.

Subprofiles R5 and R4 were studied for insects, pollen and plant macrofossils. Sample B6 (section R5; Fig. 8A) contains only a few remains of tundra beetles (Appendix 3). Xerophilous taxa (mostly Curtonotus alpinus) are dominant. Arctic species are also fairly numerous. A single fossil of a relatively thermophilous Eucnecosum cf. tenue (now living under leaf litter in southern tundra and northern forest and rare in the typical tundra) was found. The plant macrofossil 
R6

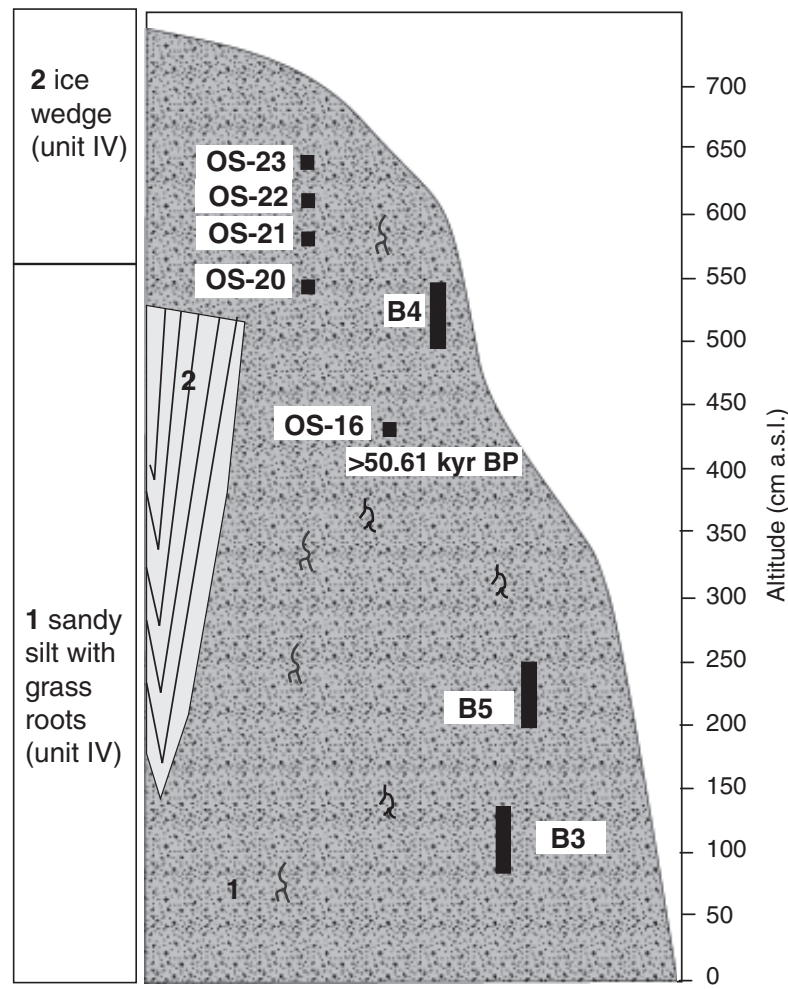

Fig. 7. Section R6. For legend, see Fig. 3.

assemblage (sample OS-25) is dominated by arctic pioneers ( $>1500$ seeds of Draba sp., Minuartia rubella, Papaver sect. Scapiflora, Cerastium beeringianum) indicative of frequent surface disturbance due to deflation and lacking protection of snow cover in winter. Other plant remains are rare (a few remains of Androsace septentrionalis and Puccinellia $\mathrm{sp}$. indicate low or instable moisture). The pollen spectrum (sample OS-26) is dominated by Poaceae, with some Caryophyllaceae and a few Cyperaceae, Valeriana, Artemisia and Brassicaceae. Remains of Pediastrum and Botryococcus colonies point to a shallow (at least periodically) aquatic environment during sedimentation.

The insect assemblage of sample B7 is similar to that of B6, but number of fossils and species diversity are lower. The pollen spectrum (sample OS-31) is dominated by Poaceae with some Cyperaceae and a few Cichoriaceae, Artemisia and Brassicaceae. There are numerous remains of Pediastrum and Botryococcus. The beetle and pollen assemblages indicate more severe climate conditions than in the B6 sample. The macrofossil assemblage (sample OS-34) is mainly composed of arctic pioneer plants (Appendix 4).

Sample B8 (section R4, Fig. 8B) was screened for insect fossils and studied for plant macrofossil and pollen. The insect assemblage is similar to that of section R5, but the role of the hygro-mesophilous group is higher. The xerophilous group consists of Curtonotus alpinus, Pterostichus sublaevis, Stereocerus haematopus and Hypera sp., which are absent on the island today. Two species of Hypera are tundra-steppe relicts and nowadays live in shrub tundra in the driest and warmest habitats. Typical arctic insects are represented by Chrysolina tolli. The pollen spectrum is dominated by Poaceae with some Artemisia and a few Cyperaceae, Valeriana and Brassicaceae. Pollen and beetles indicate climate a little warmer than reflected in the R5 samples. The species diversity of plant remains is poor and, like today's polar desert, consists of few arctic pioneer plants (Appendix 4 ). ${ }^{14} \mathrm{C}$ dated plant remains (Table 2) suggest a Middle Weichselian age of the sediments.

Section R33-A1. - An additional section exposing a thermokarst depression (unit VI) underlain by Ice Complex deposits (unit Va) was studied $3.3 \mathrm{~km}$ west of the Zimov'e River (Figs 2, 9). The sequence was penetrated by various wide and thin ice wedges. The cryostructure was massive or banded depending on the ice content, which varies between 35 and $160 \mathrm{wt} \%$.

According to ${ }^{14} \mathrm{C}$ ages (Table 1), the lower part of the section was formed during the Middle Weichselian. The general stratigraphic situation is similar to that of section R33 (Fig. 9). The upper subaquatic and subaerial sediments containing mussels, snails and thin layers with leaves, accumulated during the Lateglacial and early Holocene (12-8 $\left.{ }^{14} \mathrm{C} \mathrm{kyr} \mathrm{BP}\right)$. $3.7 \mathrm{kyr}$ BP old deposits covered the section. Woody remains ${ }^{14} \mathrm{C}$ dated between 8.4 and $8.9 \mathrm{kyr}$ BP (Table 1) were found in an ice wedge cast exposed by a steep ravine cutting the studied sediments.

Owing to a number of age inversions (Table 1), the sequence was not used for detailed palaeoecological studies. Nevertheless, the general stratigraphic information of this section is important for our understanding of environmental changes at the Lateglacial/ Holocene transition.

Sediments bearing woody remains were observed in some places on top of the steep Ice Complex cliff. Unfortunately, they could not be studied because of dangerous outcrop conditions, although an eroded piece of wood was collected, its age $\left(9.06 \pm 0.045{ }^{14} \mathrm{C} \mathrm{kyr}\right.$ BP; Table 1) confirming that alder shrubs grew on top of the Ice Complex hills during the early Holocene.

\section{Sections east of the Zimov'e River}

Section L11+40. - This lowermost subprofile of the east part of the outcrop is located $1.14 \mathrm{~km}$ east of the Zimov'e River mouth (Fig. 2) and consists mainly of bluish-grey lacustrine deposits with occasional twigs and peat inclusions (unit III) with low ice contents (c. $25 \mathrm{wt} \%$ ) and massive cryostructures (Fig. 10). The lacustrine deposits are covered by a palaeosol horizon 
A

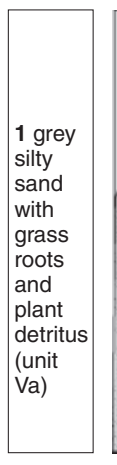

R5

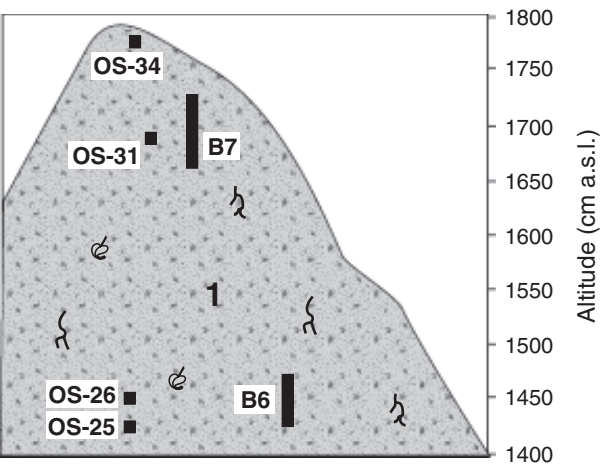

R4

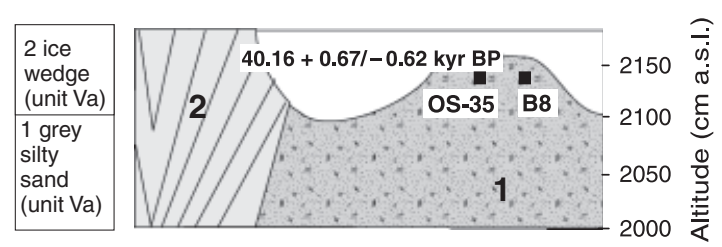

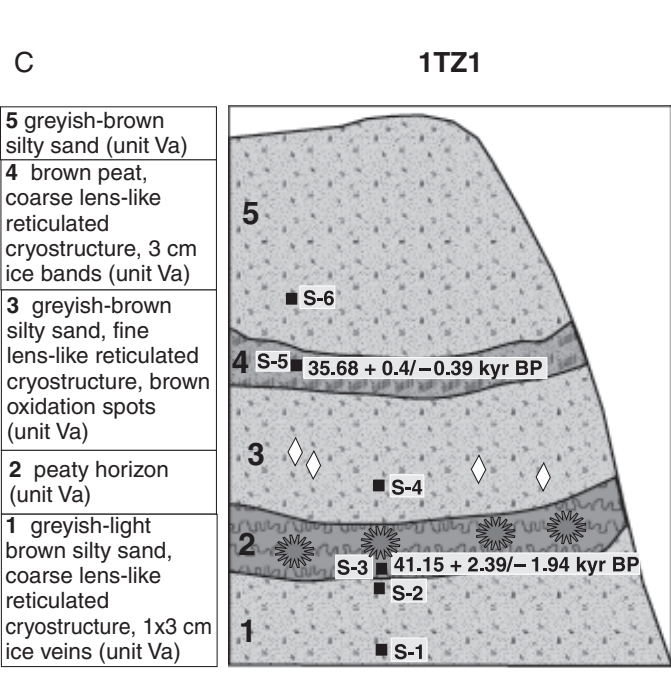

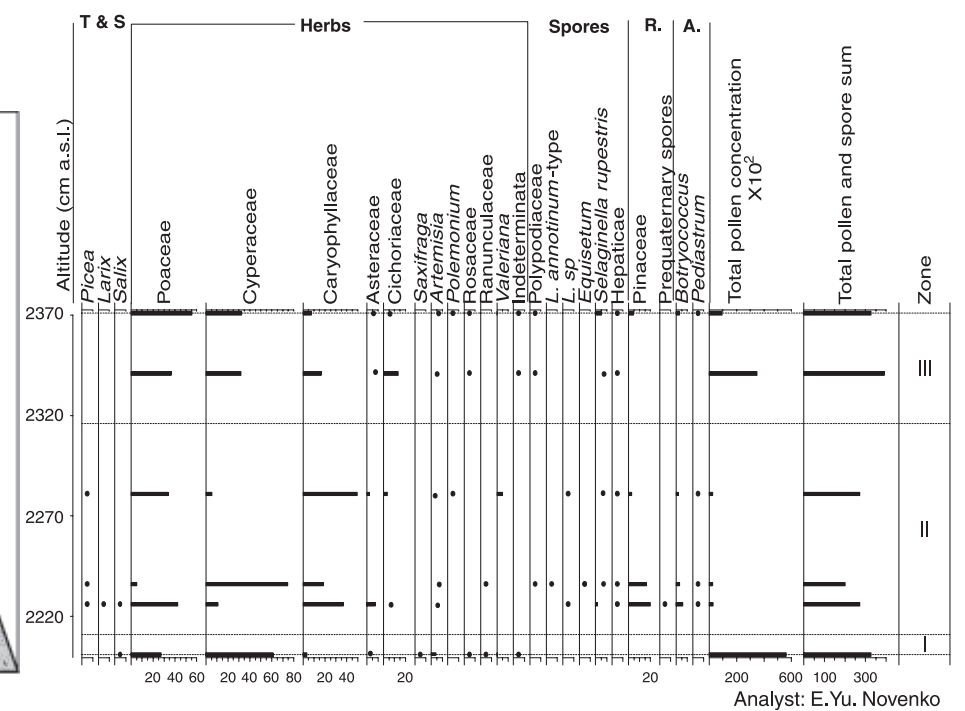

Fig. 8. Profiles, age determinations and pollen data of Ice Complex profiles within the first thermo-erosional cirque (1TZ). A. Profile of section R5. B. Profile of section R4. C. Profile and pollen percentage diagram of section 1TZ1. For legend, see Fig. 3.

and by Ice Complex deposits (unit Va) containing more ice $(c .70 \mathrm{wt} \%)$.

Pollen spectra can be subdivided into 2 PZ. Cyperaceae, Poaceae and Caryophyllaceae pollen are predominant in PZ-I. The presence of Alnus fruticosa, Betula sect. Nanae, Salix and Ericales, large amounts of reworked Pinaceae, Glomus spores, Botryococcus and Pediastrum colonies is also characteristic. PZ-II is notable for a higher presence of Salix and very low presence of Pinaceae and Glomus. Pollen concentration is much higher than in PZ-I.

Rhizopods are rare (Appendix 1). However, their good preservation points to stable accumulation environments. The lower, lacustrine samples contain hydrobiotic Pontigulasia elisa and Difflugia brevicola. Aquatic D. cratera was previously found in the Arctic only in lake sediments from the Polar Urals (Bobrov, unpublished). The upper lacustrine samples contain few eurybiotic and soil taxa. Rhizopods from all ecological groups were found in the silty-sandy oxidized horizon. Sphagnophilic Arcella discoides and large forms of Centropyxis sp. point to boggy habitats. Rhizopods from the Ice Complex sediments reflect meso-oligotrophic conditions. Eurybiotic and soil taxa (mostly minima, minuta and minor forms) from the uppermost sample reflect a rather unfavourable dry and cold environment.

The IRSL date $(37 \pm 6.5 \mathrm{kyr})$ suggests that the upper deposits (PZ-II) accumulated during the Middle Weichselian, which is in good agreement with the pollen data. Sediments below the strongly oxidized palaeosol horizon are probably much older. A pollen correlation (presence of Alnus, Betula and Ericales) with previously studied sediments (Andreev et al. 2004a; Ilyashuk et al. 2006) points to the possible late Eemian/Early Weichselian age of the sediments, which is in a good agreement with their geological position.

Section L9. - This profile (Fig. 11) is located $0.9 \mathrm{~km}$ east of the Zimov'e River and exposes a transition from light-brown fine sandy floodplain deposits with a massive cryostructure (unit IV) to grey Ice Complex deposits with peat and root inclusions, ice bands and lenslike reticulated cryostructure (unit Va). Stratigraphy and three ${ }^{14} \mathrm{C}$ ages (Table 2) suggest that the deposits accumulated after the Eemian and before about $40 \mathrm{kyr}$. The TL age of $61 \pm 15 \mathrm{kyr}(410 \mathrm{~cm}$ a.s.1.) of a sample 

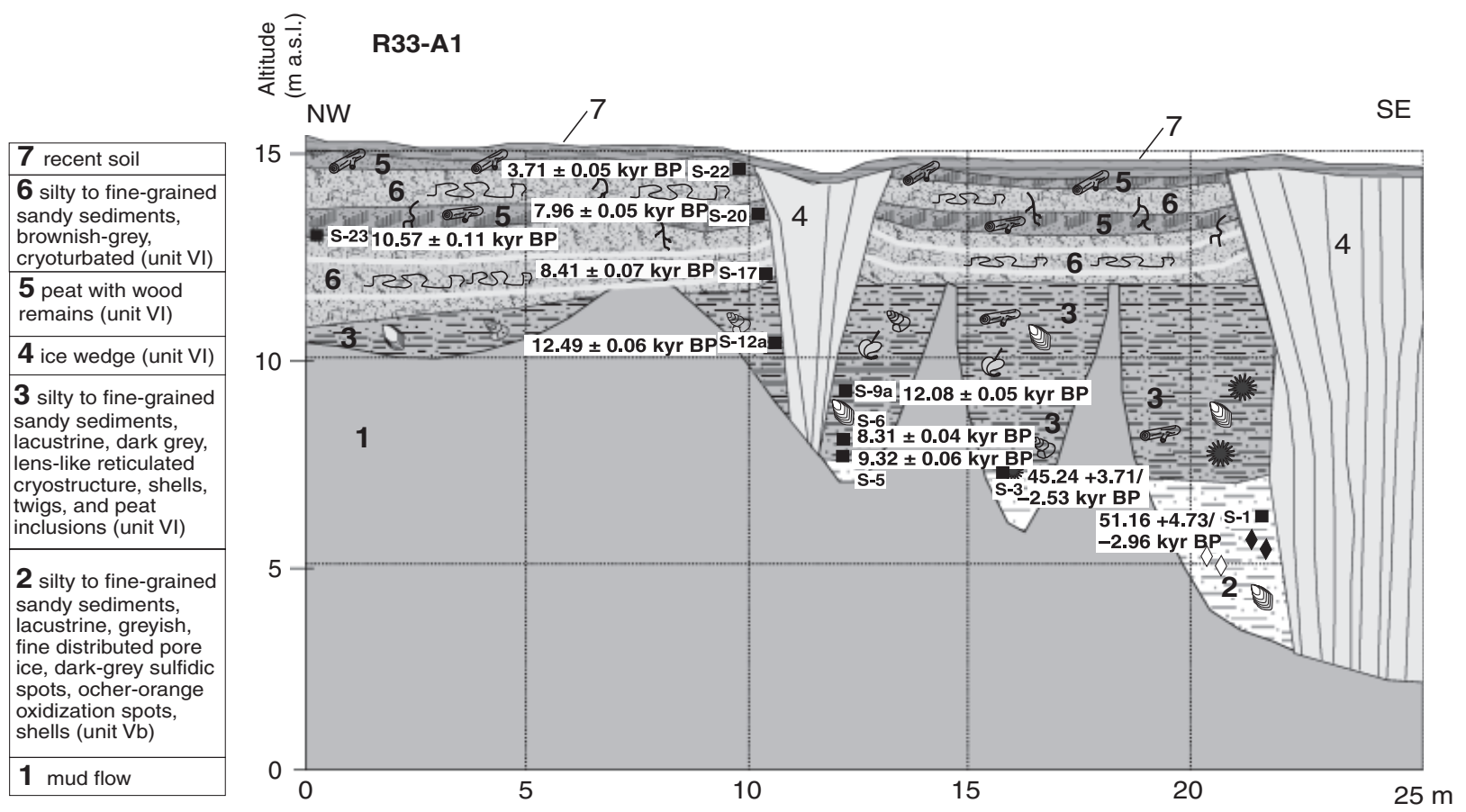

Fig. 9. Stratigraphic profile of outcrop R33-A1. For legend, see Fig. 3.

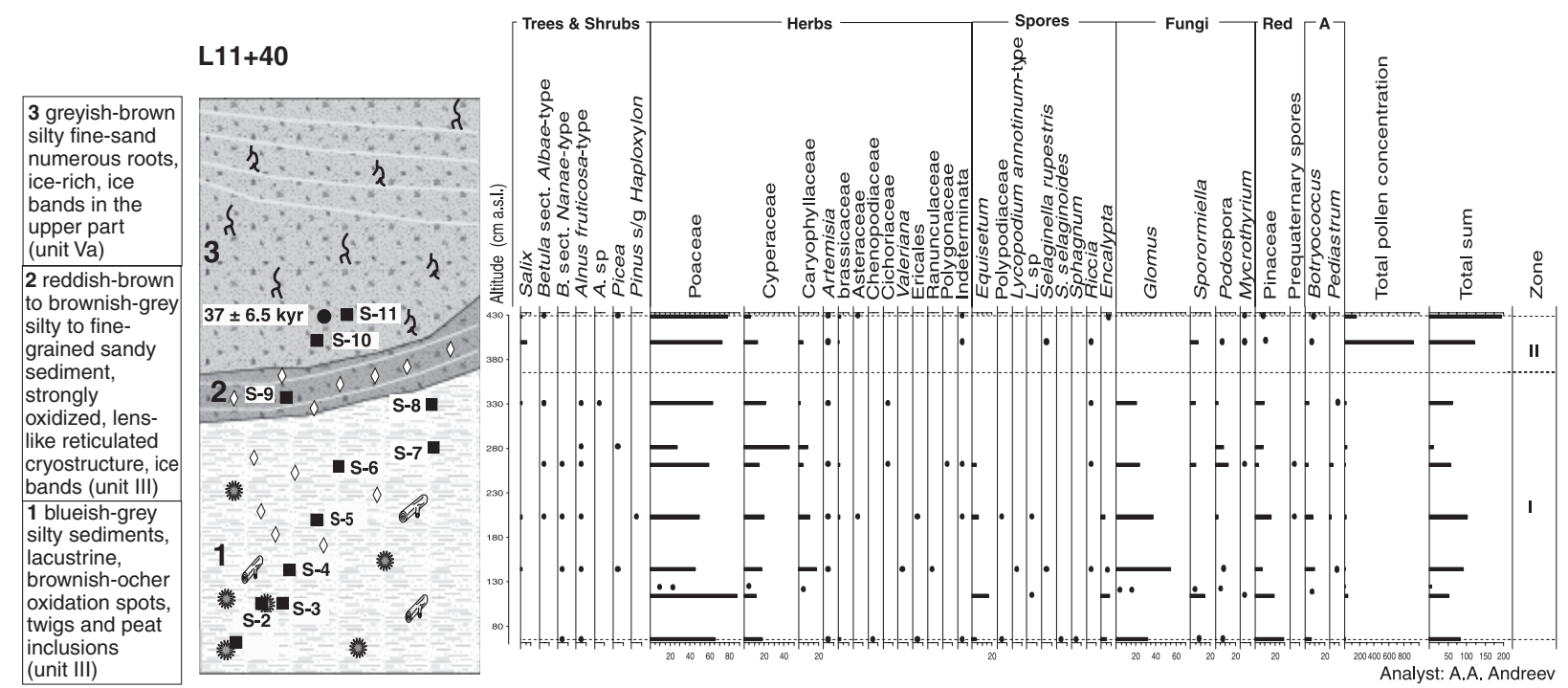

Fig. 10. Profile and pollen percentage diagram of L11+40 section. For legend, see Fig. 3.

collected in approximately the same outcrop position during previous studies is in a good agreement with the ${ }^{14} \mathrm{C}$ ages. Pollen spectra dominated mostly by Poaceae and Cyperaceae can be subdivided into $3 \mathrm{PZ}$. Pollen concentration is extremely low in PZ-I. The concentration is much higher in PZ-II, characterized by large numbers of Pediastrum colonies and reworked Pinaceae. PZ-III can be subdivided into two subzones. High amounts of Equisetum, Sordariaceae spores and algae remains (Cosmarim) are characteristic of PZ-IIIa.

A total of 51 rhizopod species, varieties and forms were found in the section (Appendix 1). The species diversity is low in the transition horizon between units IV and Va, where soil and eurybiotic taxa dominate. Rhizopods show a higher species diversity (mostly hydrophilic and sphagnophilic taxa) in the upper peaty layers, reflecting stable and rhizopod-favourable boggy environments. The higher presence of hydrophilic Difflugia and finding of Centropyxis cassis v. spinifera in the upper peat reflect a higher water table.

Section Lya97. - Several subprofiles of closely situated thermokarst mounds located $1 \mathrm{~km}$ east of the Zimov'e River mouth (Fig. 2) were collected by V. V. Kunitsky 


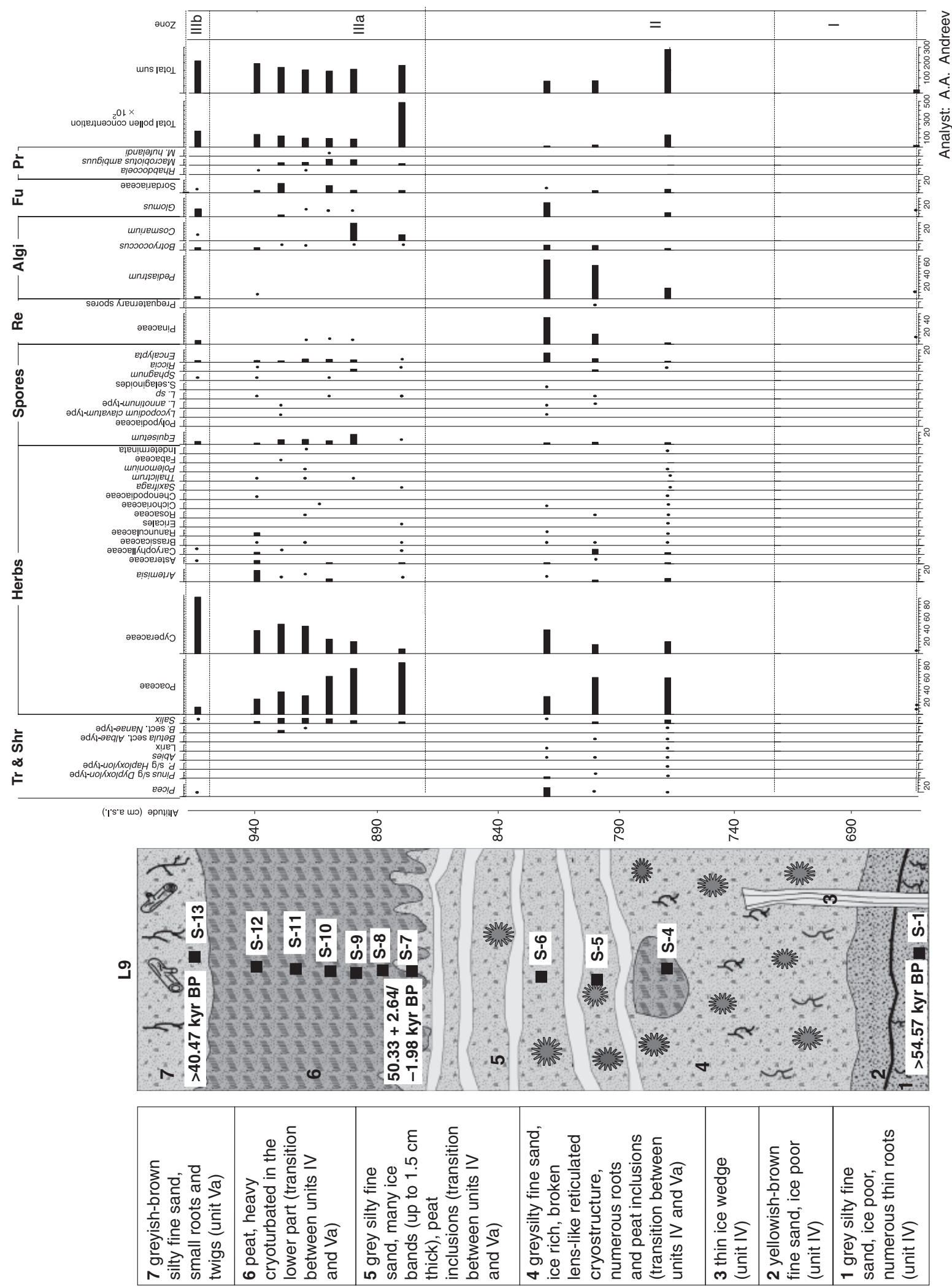

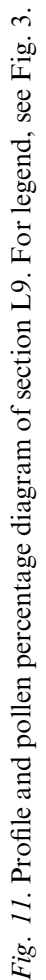


in 1997 and represent the longest profile of relatively homogeneous silty to sandy Ice Complex sediments covered by Holocene deposits. Eight ${ }^{14} \mathrm{C}$ dates (Table 2) show that the deposits accumulated during the Weichselian and early Holocene. The pollen spectra studied can be divided into 4 PZ (Fig. 12). PZ-I dominated by Poaceae with Cyperaceae and some other herb pollen is notable for its low pollen concentration and large amounts of reworked Pinaceae. PZ-II, dominated by Cyperaceae, Poaceae and Caryophyllaceae, is characterized by higher pollen concentration and very low presence of Pinaceae. PZ-III, mainly composed of Cyperaceae, Poaceae, Caryophyllaceae, Brassicaceae and Valeriana, is notable for its low pollen concentration. The concentration is higher in PZ-IV, where Betula, Alnus, Salix, Ericales, Poaceae and Cyperaceae pollen is dominant.

Section $L 21+50$. - This section (Fig. 13) is located in a large thermokarst depression of about $5 \mathrm{~km}$ in diameter c. $2 \mathrm{~km}$ east of the Zimov'e River mouth (Fig. 2). The general stratigraphic situation is similar to that of section R33 (Fig. 9). The section is composed mostly of Lateglacial/early Holocene thermokarst deposits accumulated on top of remains of Middle Weichselian $\left({ }^{14} \mathrm{C}\right.$ dates range between c. 50 and $\left.33 \mathrm{kyr} \mathrm{BP}\right)$ (Table 2$)$ bluish-grey, laminated, fine-grained deposits (unit $\mathrm{Vb}$ ) with peat inclusions, mollusc shells and a massive cryostructure (ice content $25-30 \mathrm{wt} \%$ ). The thermokarst deposits consist of dark-grey lacustrine sediments containing shells, peat inclusions and twig fragments ${ }^{14} \mathrm{C}$ dated between $c .11 .3$ and $7.6 \mathrm{kyr} \mathrm{BP}$ (Table 2). The cryostructures of these partly ice-rich (30-115 wt \%) deposits were lens-like reticulated. Large ice wedges penetrated the entire sequence. The top was covered by cryoturbated peaty palaeosols and recent peaty soil.

Pollen spectra can be divided into 5 PZ. PZ-I is notable for its relatively low pollen concentration and large amounts of reworked Pinaceae. Poaceae with Cyperaceae and some other herb pollens are dominant. PZ-II dominated by Cyperaceae, Poaceae and Caryophyllaceae is characterized by a higher pollen concentration and low presence of reworked Pinaceae. The presence of Salix pollen is also notable. PZ-III is characterized by a lower pollen concentration and higher presence of reworked Pinaceae. The pollen concentration is much higher in PZ-IV dominated by Cyperaceae, Alnus fruticosa, Betula and Poaceae. Salix and Ericales are also present. The pollen concentration is highest in PZ-V dominated by Cyperaceae, Poaceae, Alnus fruticosa, Betula and Salix.

The best modern analogue (BMA) method (Guiot 1990) was used to reconstruct past climate variables from the pollen (Fig. 14). This approach relies on the representative reference pollen/climate data set, which includes 1173 pollen spectra from northern Eurasia
(Tarasov et al. 2005). The results indicate that the climate was warmer than present around 13.5-12.5 and 10.5-8.3 cal. kyr BP, when the mean temperature of the warmest month reached $8-12^{\circ} \mathrm{C}$ and accumulated mean daily temperatures above $5^{\circ} \mathrm{C}$ (growing-degreedays, GDD5) reached $200-350^{\circ} \mathrm{C}$. Reconstructed annual precipitation values vary from c. 250 to $350 \mathrm{~mm}$, suggesting precipitation similar or slightly higher than present during the Allerød and early Holocene.

Rhizopod palaeocoenoses show high species diversity (Fig. 15). Lacustrine sediments (rhizopod zone I, (RZ-I)) contain mostly meso-oligotrophic Centropyxis and mesotrophic Cyclopyxis kahli. Although soil and eurybiotic species are dominant, taxa typical of moss bogs (sphagnophilic Trigonopyxis and Heleopera) occurred as well. It is interesting to note the finding of Argynnia sp., a rare genus previously found in the Laptev Sea region only in sediments older than $42 \mathrm{kyr}$ BP (Bobrov et al. 2004).

Species diversity and their abundance are very low in the Younger Dryas sediments (RZ-II). Centropyxis constricta v. minima and C. sylvatica v. minor are especially indicative of unfavourable soil conditions. Sediments from the Lateglacial/early Holocene transition (RZ-III) contain no rhizopods, probably indicating the reworked character of the sediments.

Rhizopods from all ecological groups were found in the lower part of RZ-IV. However, eurybiotic and soil taxa dominate. Hydrophilic Centropyxis platystoma, C. gibbosa and Difflugia limnetica point to a high water table and mesotrophic conditions. Bog Centropyxis and hydrophilic Difflugia dominate in the upper part of RZIV, pointing to mesotrophic conditions and a higher water table.

$\mathrm{RZ}-\mathrm{V}$ is characterized by high species diversity, reflecting the favourable soil environment. Hydrophilic Centropyxis and Difflugia show a high water table. Sphagnophilic Nebela and Arcella are also noticeable. Mesotrophic Centropyxis are much less abundant in the upper part of the zone, reflecting more oligotrophic conditions.

Species diversity is low in RZ-VI. The taxa point to meso-oligotrophic conditions. A rare taxon, Centropyxis gasparella v. corniculata, previously found only in modern bogs of Victoria Island, Canada (Beyens \& Chardez 1997) was found there.

The sediments have also been analysed for diatoms (Appendix 2). An Allerød dated sample (S-6) contains mostly lacustrine and bog taxa $(55 \%)$, but soil species are common as well $(34 \%)$. The sample above (S-7) contains more benthic $(53 \%)$, littoral $(20 \%)$ and less soil $(7.5 \%)$ taxa. Benthic diatoms $(76.5 \%)$ dominated in sample S-8. No diatoms have been found in sediments accumulated during Lateglacial/early Holocene transition. Early Holocene samples (S-12 and S-14) have the highest species diversity, with a dominance of benthic taxa (up to 59\%). Lacustrine-bog species 

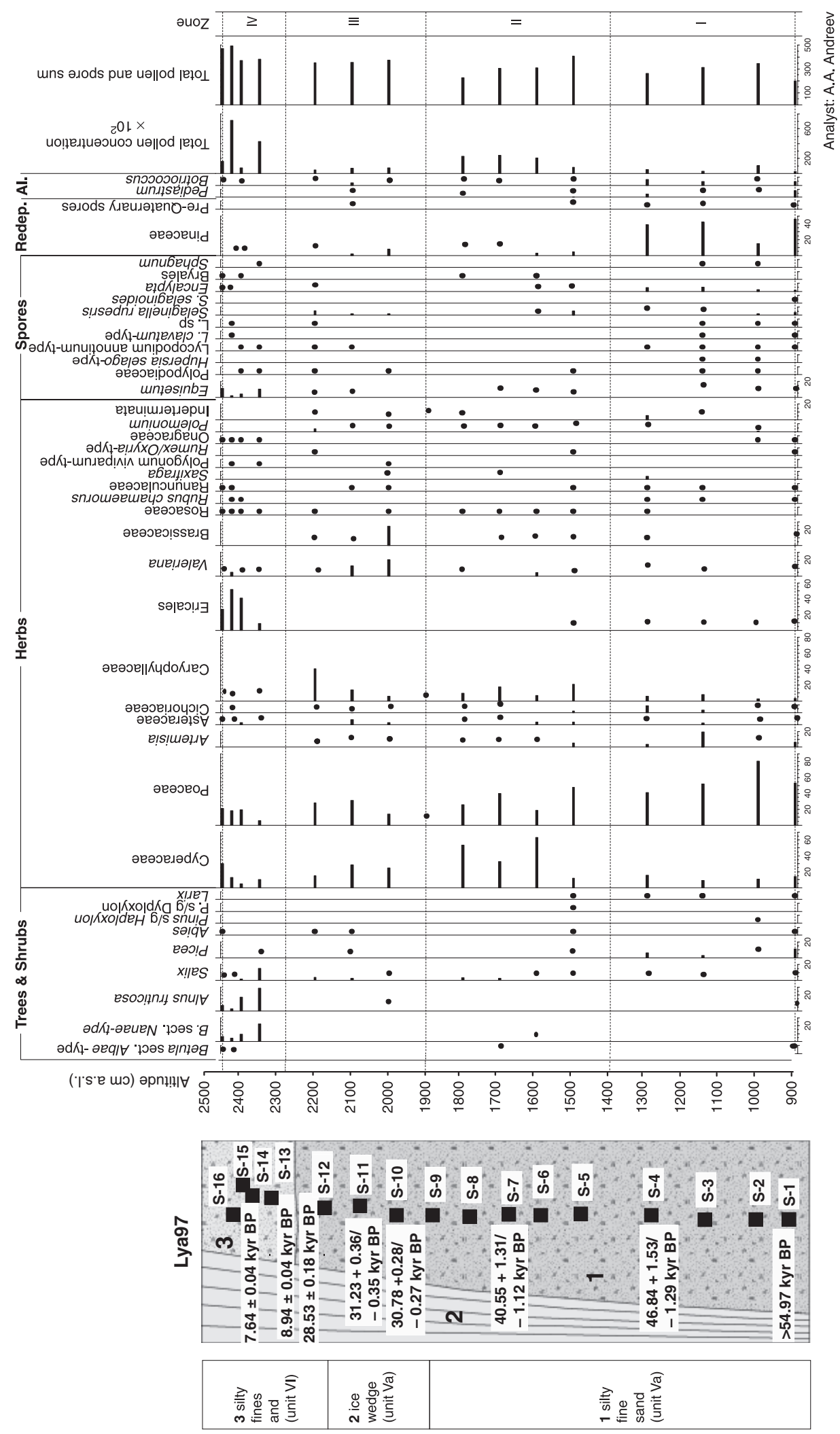


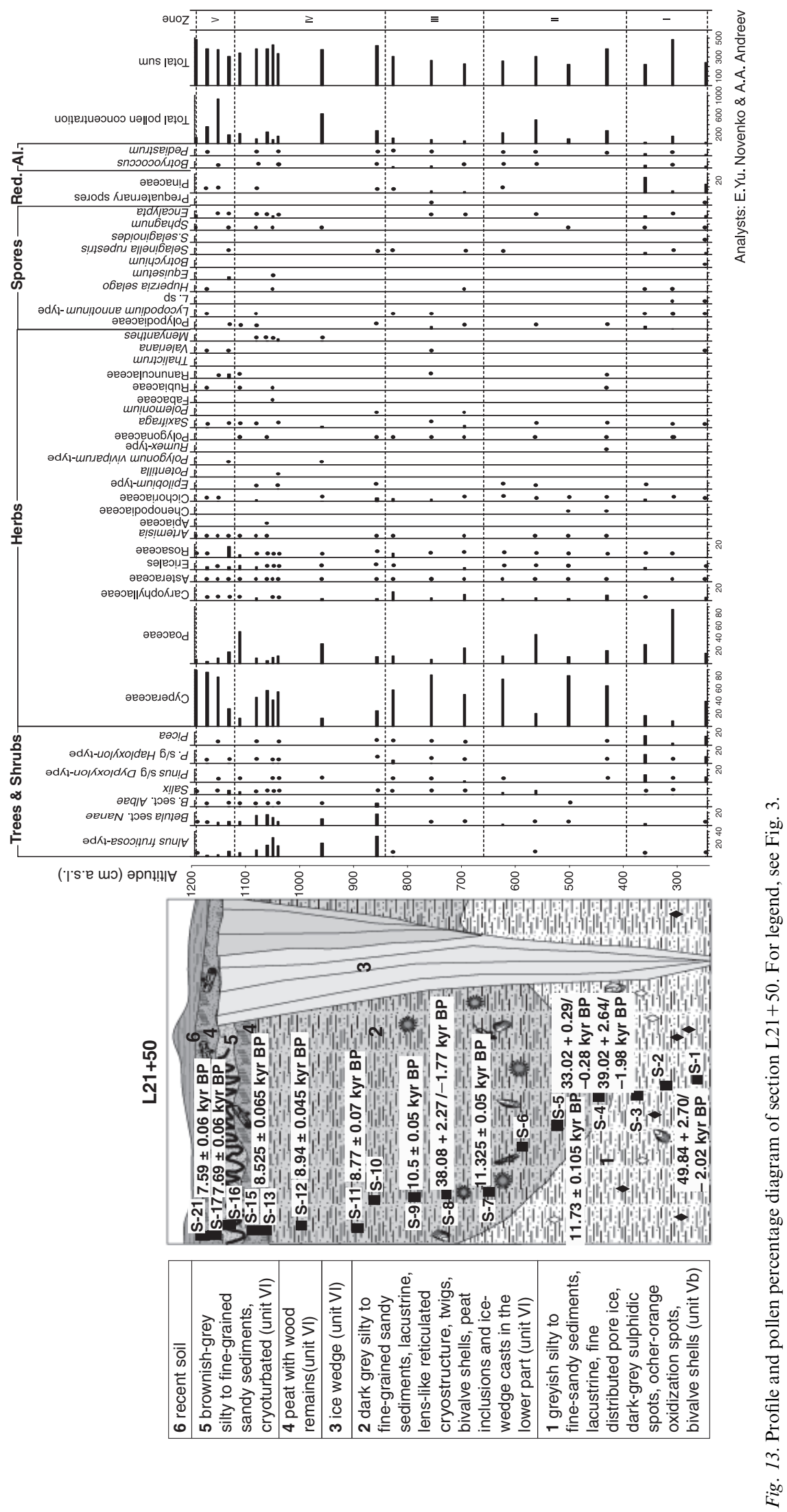



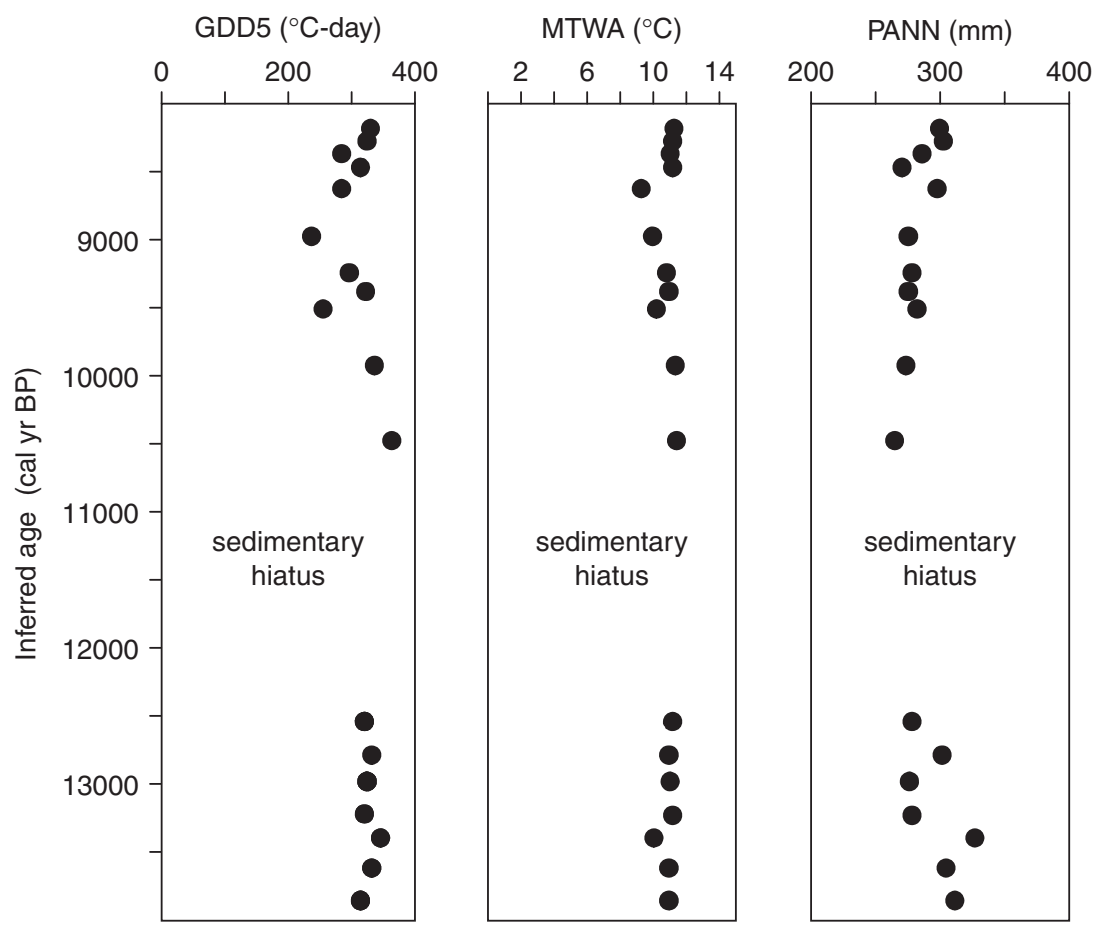

Fig. 14. Climate reconstruction inferred from $\mathrm{L} 21+50$ pollen record. GDD5 $\left({ }^{\circ} \mathrm{C}\right.$-day $)=$ annual sum of the growingdegree-days above $5^{\circ} \mathrm{C}$; MTWA $\left({ }^{\circ} \mathrm{C}\right.$ day $)=$ mean temperature of the warmest month; PANN $(\mathrm{mm})=$ annual precipitation. Most probable values are based on the weighted average of the 8 best modern analogues. are also abundant (up to $35 \%$ ). Eunotia valida, a taxon typical of bog environment, was dominant in sample S-15.

Section L17. - This section belongs in the same thermokarst depression as section $\mathrm{L} 21+50$. The deposits vary from sandy lacustrine sediments full of plant detritus and fresh water mollusc shells to silt and sand with peat inclusions, which are covered by a peat bed (Fig. 16). The section was studied for insects and pollen. The lowest sample (B22) was collected in a layer between the older sandy-silt deposits and the Holocene alas sediments. Its pollen spectrum is mostly dominated by herbs, but contains numerous Salix, Betula nana and some Alnus fruticosa pollen as well. Similar deposits in section $\mathrm{L} 21+50$ were dated to Aller $\varnothing \mathrm{d}$. The numerous water predaceous diving beetles (Appendix 3) confirm the lacustrine origin of the sediments. Other beetles are represented by tundra species, mostly mesophilous taxa $(39 \%)$; arctic species $(15 \%)$ are present as well. The xerophilous Notiophilus aquaticus and Dicheirotrichus mannerheimi indicate climate conditions less severe than today.

The upper sample (B20) was collected in a layer rich of woody remains (mostly Alnus fruticosa) ${ }^{14} \mathrm{C}$ dated to $8.02 \pm 0.035 \mathrm{kyr}$ BP. The pollen concentration is very high and Alnus fruticosa pollen dominates. The rich insect assemblage includes species of tundra, steppe, shrubs, water and riparian environments (Appendix 3). The tundra mesophilous group dominates $(50 \%)$. The tundra xerophilous group is less abundant (17\%), but its species diversity is higher. Arctic insects are represented only by Isochnus arcticus. Curiously, typical tundra-steppe insects Morychus viridis and Stephanocleonus eruditus were found. The assemblage includes a number of insects more common in the southern shrub tundra and forest-tundra zones (e.g. an ant, Leptothorax acervorum, now living in taiga and occasionally in southern tundra).

The uppermost sample (B21) taken from peaty deposits was ${ }^{14} \mathrm{C}$ dated to $3.7 \pm 0.03 \mathrm{kyr}$ BP. Its pollen spectrum is mostly composed of Poaceae with a few Cyperaceae, Valeriana and Epilobium, but also numerous Betula nana. The number of fossil insects and their diversity is low (Table 3, Appendix). Only species living on the island nowadays were found. Arctic $(59 \%)$ and tundra mesophilous $(36 \%)$ species dominate. A few remains of a xerophilous ground beetle and water beetle were also found. The insect assemblage indicates a severe Arctic environment similar to the recent one. Many specimens have aberrations, such as additional wrinkles on the chitin surface and irregularly shaped elytra, which are probably the result of frost influence.

\section{Large mammal fossils}

More than 1100 bones or bone fragments were collected along the south coast during the 1999 expedition. When possible, bone finds were correlated with sediment units and stratigraphic position. However, the major part of the collection consists of relocated bones found at the shore.

The bone collection was divided into groups based on the locations where the bones were found. Two 


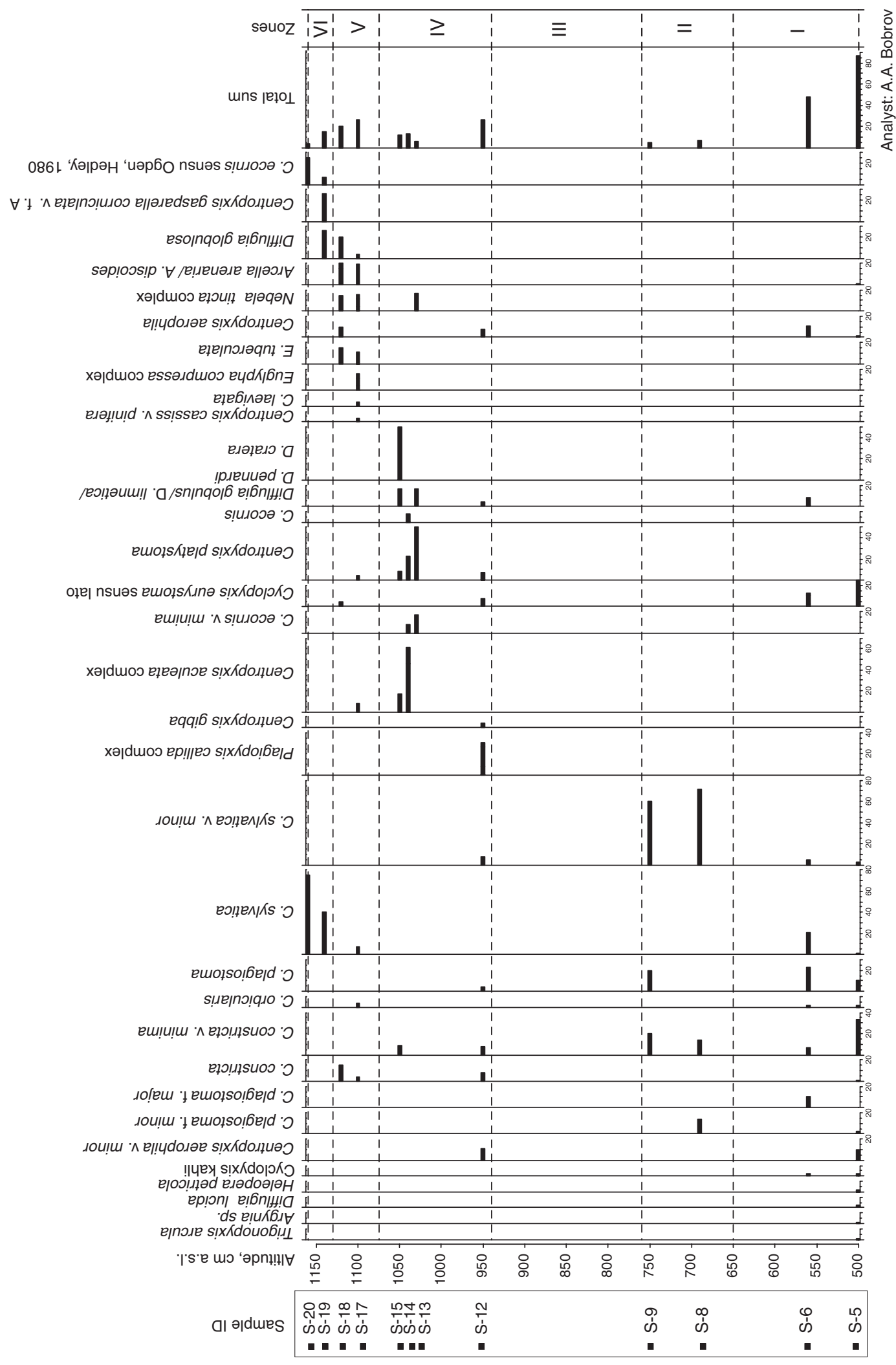


L17

\begin{tabular}{|l|}
\hline $\mathbf{4}$ recent soil \\
\hline $\mathbf{3}$ peat layer \\
\hline $\mathbf{2}$ lacustrine \\
sandy silt \\
withplant \\
detritus, \\
twigs of \\
large \\
shrubs and \\
peat lenses \\
(unit VI) \\
\hline $\mathbf{1}$ lacustrine \\
sandy silt \\
with peat \\
inclusions \\
(unit VI) \\
\hline
\end{tabular}

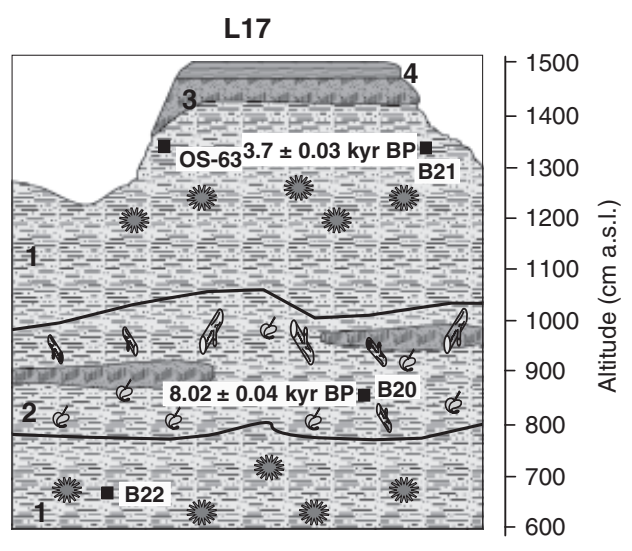

Fig. 16. Section L17. For legend, see Fig. 3.

bone groups could be used for direct stratigraphic interpretation. The first group consists of 33 bones discovered in situ. The second group consists of 54 bones deposited in several 'bone fields' beneath the vertically exposed Ice Complex (predominantly in the first, second and third TZ). For these, it was possible to define the bone source area with a certain probability. The altitude of their lower boundaries was instrumentally defined as the level of minimum height of the original bone position.

The taxonomic composition of the collected bones is typical of the 'mammoth fauna' in NE Siberia. Bones of Mammuthus primigenius (25.8\%), Equus sp. (25\%), Bison priscus (19.8\%) and Rangifer tarandus (18.3\%) are predominant (Kuznetsova et al. 2001). Other bones belong to Ovibos moschatus (7.2\%), Lepus sp. (2.4\%), Coelodonta antiquitatis $(0.7 \%)$, carnivores $(0.7 \%)$ and Saiga sp. $(0.2 \%)$. A total of $86{ }^{14} \mathrm{C}$ dates were obtained from bone collagen (Fig. 17). Despite the identified sedimentary gap between 30 and $12 \mathrm{kyr} \mathrm{BP}$, the finite bone ages group predominantly between 44 and $20 \mathrm{kyr}$ $\mathrm{BP}$ with no large temporal gaps. The bones ${ }^{14} \mathrm{C}$ dated in the period of the sedimentary gap are those of Mammuthus primigenius, Coelodonta antiquitatis, Equus sp. and Ovibos moschatus. The largest number of dated bones falls within the period between 44 and $32 \mathrm{kyr}$ BP. Most of the infinite dated bones probably originate from the lower parts of the outcrops, which are older than $45 \mathrm{kyr}$ BP.

About half of the mammal bone collection consists of woolly mammoth and horse remains; correspondingly, the bulk of ${ }^{14} \mathrm{C}$ ages belong to woolly mammoth (35 dates) and horse (21 dates). The youngest mammoth bone is ${ }^{14} \mathrm{C}$ dated to $12.03 \pm 0.06 \mathrm{kyr} \mathrm{BP}$ and the youngest horse bone to $2.2 \pm 0.05 \mathrm{kyr} \mathrm{BP}$. This horse bone date is currently the youngest horse age from the Arctic and supports the results of our previous studies (Schirrmeister et al. 2002b) suggesting that horses lived in the east Siberian Arctic during the late Holocene. A single find of a saiga bone was dated to $46.79 \pm 1.18 \mathrm{kyr}$ BP. This antelope is a good indicator of firm and dry soil surface in summer and very thin snow cover in winter (typical cold steppe conditions).

\section{Isotope signatures of ice wedges and palaeoclimatic implications}

The isotopic composition of ice wedges enhances the stratigraphic subdivision of the sediments into geocryological units (Meyer et al. 2002b) and is used for reconstructing palaeoclimatic fluctuations. Snow is the main agent for ice-wedge growth. Thus, the stable isotopic composition of ice wedges is interpreted as being indicative of mean winter temperatures. For more detail on the relation between snow and ground ice isotopic compositions, see Meyer et al. (2002b).

Direct ${ }^{14} \mathrm{C}$ dating of organic matter inclusions in the ice was possible for a number of ice wedges (Table 1). These dates are generally in good accordance with ages of the surrounding sediments for the Ice Complex (unit Va). Beyond the typical late Pleistocene syngenetic ice wedges of the Ice Complex, Holocene development of ice wedges in a thermo-erosional valley was confirmed with an age of $3.44 \pm 0.03{ }^{14} \mathrm{C}$ kyr BP. Epigenetic ice wedges in a thermokarst depression were formed during the last $1 \mathrm{kyr}$, as indicated by two ${ }^{14} \mathrm{C}$ dates (Table 2). Additionally, tritium analyses reveal recent ice wedge growth in alas and fluvial deposits (Dereviagin et al. 2002).

A clear chronological development of the stable isotopic composition of ice wedges from different periods is depicted in $\delta^{18} \mathrm{O} / \delta \mathrm{D}$ diagrams (Fig. 18). Ice wedges of unit IV show a very light mean isotopic composition with $\delta^{18} \mathrm{O}$ of $-35.5 \%$ and $\delta \mathrm{D}$ of $-280 \%$ (Meyer et al. $2002 b$ ), indicating very low winter temperatures. The mean $\delta^{18} \mathrm{O}$ and $\delta \mathrm{D}$ values of Ice Complex ice wedges range from $-32.5 \%$ to $-28.5 \%$ and from $-250 \%$ to $-220 \%$, respectively (Fig. 18A), and are similar to those of the Saalian Ice Complex of age (unit I) showing a mean isotopic composition around $-32 \%$ for $\delta^{18} \mathrm{O}$ and $-250 \%$ for $\delta \mathrm{D}$ (Meyer et al. 2002b). Therefore, winter temperatures were probably relatively cold and stable between about 50 and $28.7 \mathrm{kyr}$ BP. Compared to previous studies (Meyer et al. 2002b), an additional ice wedge was analysed for stable isotopes. Plant remains found there were ${ }^{14} \mathrm{C}$ dated to $39.7+1.3 /-1.1 \mathrm{kyr} \mathrm{BP}$.

The Holocene ice wedges reflect much warmer winter temperatures: ice wedges from two alases (unit VI) show a mean $\delta^{18} \mathrm{O}$ of $24.5 \%$ and $\delta \mathrm{D}$ of $-190 \%$ (Fig. 18B), reflecting much heavier isotopic composition than in the older units; wedges in thermo-erosional valley deposits (unit VI) show a mean $\delta^{18} \mathrm{O}$ of $-27.5 \%$ and $\delta \mathrm{D}$ and $-200 \%$ (Fig. 18C). Climate amelioration at the Pleistocene/Holocene boundary is reflected in a rise of about $6 \%$ in $\delta^{18} \mathrm{O}$ and of about $40 \%$ in $\delta \mathrm{D}$. Ice-wedge growth in alas and thermo-erosional valleys probably started with the late Holocene climate 


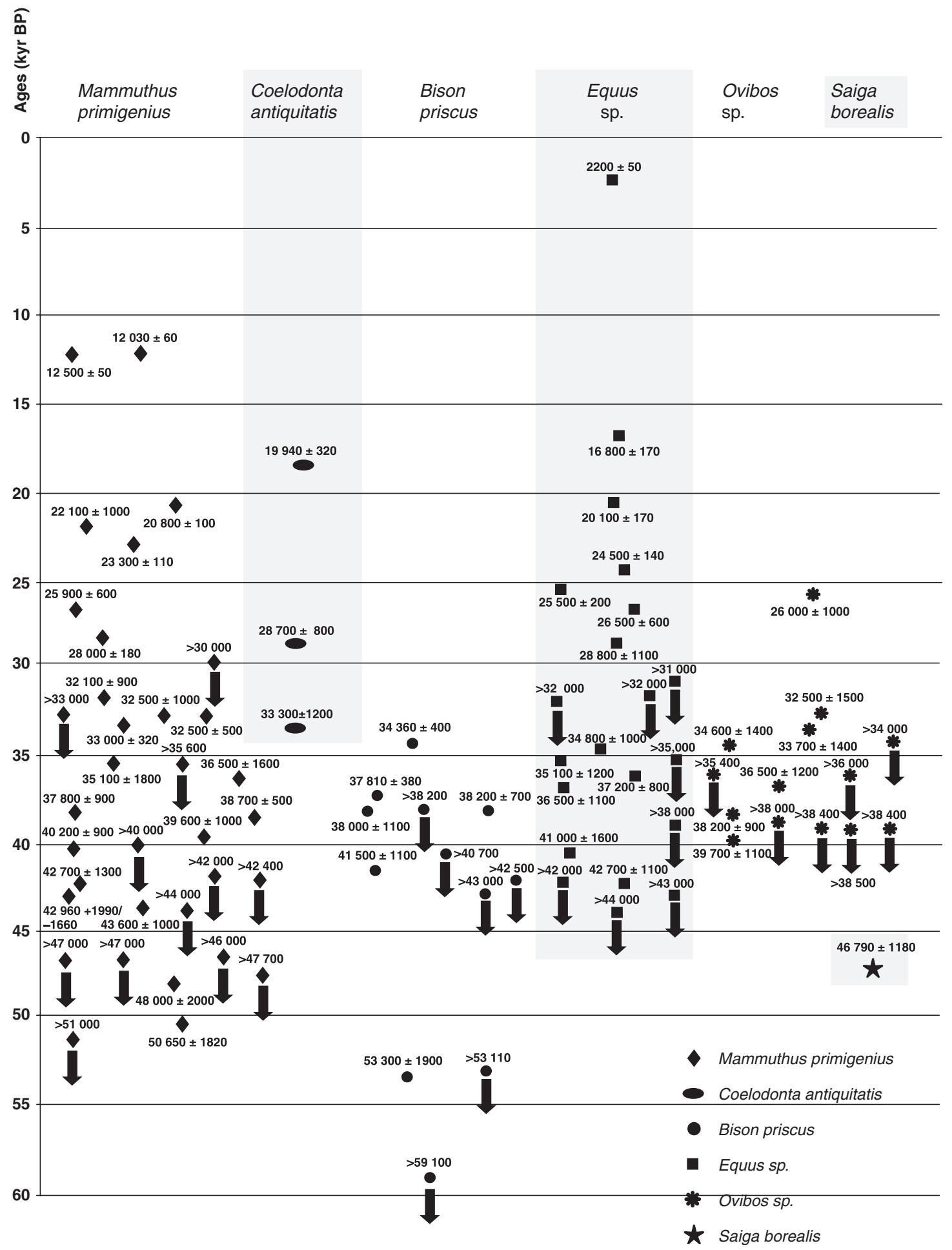

Fig. 17. Radiocarbon dated mammal bones from Bol'shoy Lyakhovsky Island.

deterioration. Alas ice wedges indicate slightly warmer winter conditions when compared to those of thermoerosional valleys. A subrecent ice wedge in fluvial deposits of the Zimov'e River indicates even warmer winter temperatures (Fig. 18D) with mean $\delta^{18} \mathrm{O}$ of $-23 \%$ and $\delta \mathrm{D}$ of $-180 \%$, respectively. Recent ice wedges sampled in the active layer of thermo-erosional valleys, alases and fluvial deposits, and identified by their high tritium concentrations (Dereviagin et al. 2002), show the heaviest isotopic composition (-20.4\%o in $\delta^{18} \mathrm{O}$ and $-160 \%$ in $\left.\delta \mathrm{D}\right)$, indicating that winter temperatures reached the highest values at the present time. 


\section{Discussion: palaeoenvironmental reconstructions}

Transition from the Eemian interglacial to the postEemian stadial (Early Weichselian, Zyryan)

The oldest pollen spectra are presented in the lower parts of sections R23+40 (PZ-I; Fig. 3) and L11+40 (PZ-I; Fig. 10). Similar pollen spectra were found in the upper part of the section $\mathrm{R} 22+60$ (Andreev et al. 2004a). The geological position of the sections and their pollen assemblages (presence of Alnus fruticosa, Betula sect Nanae and Ericales) suggest the late Eemian age and/or transition to Early Weichselian. The vegetation during this interval was similar to modern subarctic tundra. The pollen-based climate reconstruction suggests similar to present-day conditions (Andreev et al. 2004a).

Obligate hydrobiotic rhizopods (Difflugia species and Pontigulasia elisa) found in the lower part of section L11 confirm a lacustrine sedimentation environment. Well-preserved shells point to stable accumulation conditions. The upper lacustrine sediments contain mostly eurybiotic and soil taxa, pointing to changes in the sedimentation (larger terrestrial input).

It is difficult to estimate the time of the beginning and of the duration of this transition interval, but the TL ages $(114 \pm 28$ and $96 \pm 26 \mathrm{kyr})$ from the R $23+40$ section and IRSL dates from the R22+60 section (102 \pm 16 and $99 \pm 15 \mathrm{kyr}$ ) are in a good agreement with late Eemian and/or Early Weichselian age of the sediments. We date this interval to $c$. 115-100 kyr BP.

\section{Early Weichselian (Zyryan Stadial)}

Early Weichselian sediments are abundant in the area. Their pollen spectra (3TZ5 (Fig. 4A), PZ-I of 3TZ1 (Fig. 4C), PZ-1 of R18+50 (Fig. 5), PZ-I of 2TZ1 (Fig. 6a), PZ-I-II of L9 (Fig. 11), PZ-I of Lya97 (Fig. 12)) reflect harsh environmental conditions; sparse vegetation (mostly grass and sedge communities) during this time and/or low pollen production. Relatively high contents of reworked pollen mirror the erosion of older deposits confirming sparse vegetation. The dominance of arctic pioneer plants clearly indicates a thin snow cover in winter. Numerous steppe indicators, e.g. Artemisia frigida and Potentilla stipularis, and the constant occurrence of Puccinellia (characteristic of fluctuating moisture and salt accumulation due to high evaporation) also point to low precipitation. Only a few cold-adapted beetles (including Morychus viridis, a good indicator of tundra-steppe environment) were found.

However, the relatively high contents of green algae colonies found in many samples suggest an at least periodically aquatic sedimentation. Numerous benthic, periphytic and littoral diatoms from the $3 \mathrm{TZ1}$ sediments confirm that freshwater basins existed during the
Early Weichselian. Generally, the diatom palaeocoenoses are similar to those previously found in late Pleistocene sediments in the Zimov'e region (Pirumova 1968; Pirumova \& Rybakova 1984). Although rhizopods are rare in the Early Weichselian sediments (only in L9 section, where soil and eurybiotic species are predominant), the presence of typical hydrophilic Difflugia taxa points to wet habitats as well. We assume that sediment accumulation during the Early Weichselian occurred in small ponds in a polygonal tundra landscape.

As with the earlier interval, the duration of the Early Weichselian stadial is difficult to determine because of the infinite character of radiocarbon dates. Considering the suggested duration of the interval described above, it is estimated that the stadial began $c$. $100 \mathrm{kyr}$ and ended $c$. $50 \mathrm{kyr} \mathrm{BP}$ with the beginning of the Middle Weichselian (Karginsky) interstadial.

\section{Middle Weichselian (Karginsky Interstadial)}

Middle Weichselian records are also numerous (3TZ2 (Fig. 4B), PZ-II of 3TZ1 (Fig. 4C), PZ-II of 2TZ1 (Fig. 6A), PZ-I of 2TZ2 (Fig. 6B), 1TZ1 (Fig. 7), PZ-II of L11 + 40 (Fig. 10), PZ-III of L9 (Fig. 11) and PZ-II of Lya97 (Fig. 12)). They reflect some amelioration of the harsh environmental conditions predominant during the previous interval. The higher pollen concentrations reflect a denser grass-sedge-dominated vegetation and/ or an increase of pollen production. Lower amounts of reworked Pinaceae and the presence of Salix are also characteristic of the Middle Weichselian spectra. Similar pollen spectra are common for the Middle Weichselian sediments from other sites in the Laptev Sea region (Andreev et al. 2002a; Schirrmeister et al. 2002b, 2003 and references therein). Open vegetation dominated, although willow shrubs occurred possibly in more protected places.

Middle Weichselian plant macrofossil assemblages do not differ much from Early Weichselian assemblages. Arctic pioneer plants dominate the spectra with a small admixture of steppe plants and Puccinellia (a good indicator of fluctuating moisture and salt accumulation due to high evaporation). Sparse tundra-steppe vegetation can be reconstructed from such assemblages. However, it must be noted that the studied plant remains are poorly preserved, possibly resulting in biases due to selective decay.

The deposits often contain peat and peaty soils relatively rich in rhizopods (eurybiotic taxa in second palaeosol of the 3TZ2 profile; relatively rich rhizopod palaeocoenoses in both peaty layers of the 3TZ1 profile). The ecological structure of 3TZ1 communities is similar to that of modern mesotrophic/oligotrophic bogs with hydrophilic taxa pointing to rather wet habitats. The 3TZ1 samples also contain large amounts of freshwater diatom valves, confirming that water bodies 
existed. However, relatively high contents of soil taxa show that such small basins or polygonal ponds were periodically dried up and soil formation processes started. It is likely that these shallow ponds and basins were just seasonal or perennial water bodies and not related to thermokarst formation.

Rhizopods from all ecological groups were found in the oxidized horizon of the L11 profile. Sphagnophilic Arcella discoides points to boggy habitats. Rhizopods from the upper sediments reflect meso-oligotrophic boggy conditions. Very rich rhizopod palaeocoenoses (51 taxa) were found in the peat horizon of profile L9. Hydrophilic and sphagnophilic taxa mostly reflect a rather stable boggy environment. The higher presence of hydrophilic taxa in the upper peat points to a higher water table.

Middle Weichselian insect assemblages (sections $\mathrm{R} 18, \mathrm{R} 5$ and R4) consist of few tundra species remains, indicating a severe environment similar to the modern. The role of the hygro-mesophilous group is higher in R4, where remains of Hypera sp. (absent on the island today) were found. Their presence may indicate rather dry and warm summer conditions. Generally, the R4 assemblage indicates a slightly warmer climate than reflected in the R5 and R18 assemblages.

The largest part of ${ }^{14} \mathrm{C}$-dated mammal bones belongs to the 44-32 kyr BP interval, reflecting that grazing herds were more numerous during this interval.

Thus, all biological remains (except of plant macrofossils, which do not reflect changes compared to the Early Weichselian) point to climate amelioration during the Middle Weichselian. The relatively moderate interval c. 50-30 kyr BP is also evident at other locations in northern Siberia (e.g. Anderson \& Lozhkin 2001; Andreev et al. 2002a, b, 2006 and references therein). Climate conditions became colder and drier after $c .30 \mathrm{kyr} \mathrm{BP}$, according to the Lya97 record.

Stable isotopes from the Middle Weichselian ice wedges reflect severe conditions, but although winter temperatures were assumed as being relatively cold and stable between about 50 and $28.7 \mathrm{kyr}$ BP, they were warmer than in the previous interval, indicating a slight decrease in seasonality.

\section{Late Weichselian (Sartan)}

Despite a few, probably reworked, plant and shell remains in thermokarst depressions dated to about 12 kyr BP (Table 2), no sediments ${ }^{14} \mathrm{C}$ dated between c. 28.5 and $12 \mathrm{kyr}$ BP were found. Most likely this reflects active erosion processes during or at the end of the interval. Bones of Mammuthus primigenius, Coelodonta antiquitatis, Ovibos moschatus and Equus sp. dated between 26.5 and $12.5 \mathrm{kyr}$ BP (Fig. 17) are the only evidence of the Sartan environment documenting that these herbivores lived there during this time. It is unclear whether the Sartan sediments were destroyed widely or only locally at specific outcrops like Lya97 (Fig. 12). Unfortunately, many of the sections in higher elevations of the steep Ice Complex bluffs that might include Sartan sediments could not be studied for safety reasons.

\section{Lateglacial and Holocene}

Generally, Lateglacial terrestrial palaeoenvironmental records are rare in the Laptev Sea region because of the active, thermokarst-related, landscape dynamics. In the area studied, Lateglacial and Holocene sediments are preserved in some thermokarst depressions and as a thin cover on top of the Ice Complex. Section L21+50 (Fig. 13) is the most representative. Its PZ-II spectra (two ${ }^{14} \mathrm{C}$ dates: $11.57 \pm 0.09$ and $11.325 \pm 0.05 \mathrm{kyr}$ BP confirm the Allerød age) are dominated mostly by Cyperaceae and Poaceae. However, the presence of Salix and Betula sect. Nanae pollen points to a relatively warm climate (dwarf birch is absent in the modern vegetation). Similarly dated pollen spectra from the Tiksi area $\left(11.8-11.2{ }^{14} \mathrm{C}\right.$ kyr BP; Grosse et al. 2007) and Kotelny Island $\left({ }^{14} \mathrm{C}\right.$ bulk date is $12.29 \pm 0.13 \mathrm{kyr}$ BP; Makeyev et al. 2003) are also characterized by large amounts of birch. Thus, shrubby tundra vegetation pointing to a relatively warm climate dominated in the Laptev Sea region during the Allerød. Pollen-based climate reconstructions (Fig. 14) show that the summer temperature reached $8-12^{\circ} \mathrm{C}$ and GDD5 values of 200-350 ${ }^{\circ} \mathrm{C}$. Annual precipitation was similar to that of the present $(250-350 \mathrm{~mm})$. A strong warming of winter temperatures at the Pleistocene/Holocene transition is also evident in a sharp increase of $\delta^{18} \mathrm{O}$ and $\delta \mathrm{D}$ values in Holocene ice wedges (Fig. 18).

The Allerød sediments also contain rhizopods and diatoms. Although soil and eurybiotic rhizopods, indicating mesotrophic conditions, are dominant, sphagnophilic taxa typical of moss bogs occurred as well. Lacustrine and bog diatoms are dominant $c .11 .5 \mathrm{kyr}$ $\mathrm{BP}$, but some soil species point to periodic drying events. The sediments accumulated $c .11 .3 \mathrm{kyr}$ BP contain more benthic and littoral taxa reflecting a rather shallow water environment in the palaeolake.

The insect record (section L17), with a number of water predaceous diving beetles, also confirms the lacustrine origin of the sediments. Other fossil beetles are represented by tundra species, with mesophilous taxa dominating. The remains of xerophilous Notiophilus aquaticus and Dicheirotrichus mannerheimi indicate climate conditions less severe than now. Thus, both pollen and beetles reflect a climate warmer than modern.

Pollen concentration is significantly lower in the sediments ${ }^{14} \mathrm{C}$ dated to 10.5 kyr BP (PZ-III of Fig. 13), reflecting a climate deterioration possibly correlating with the Younger Dryas. Similar dated pollen records 

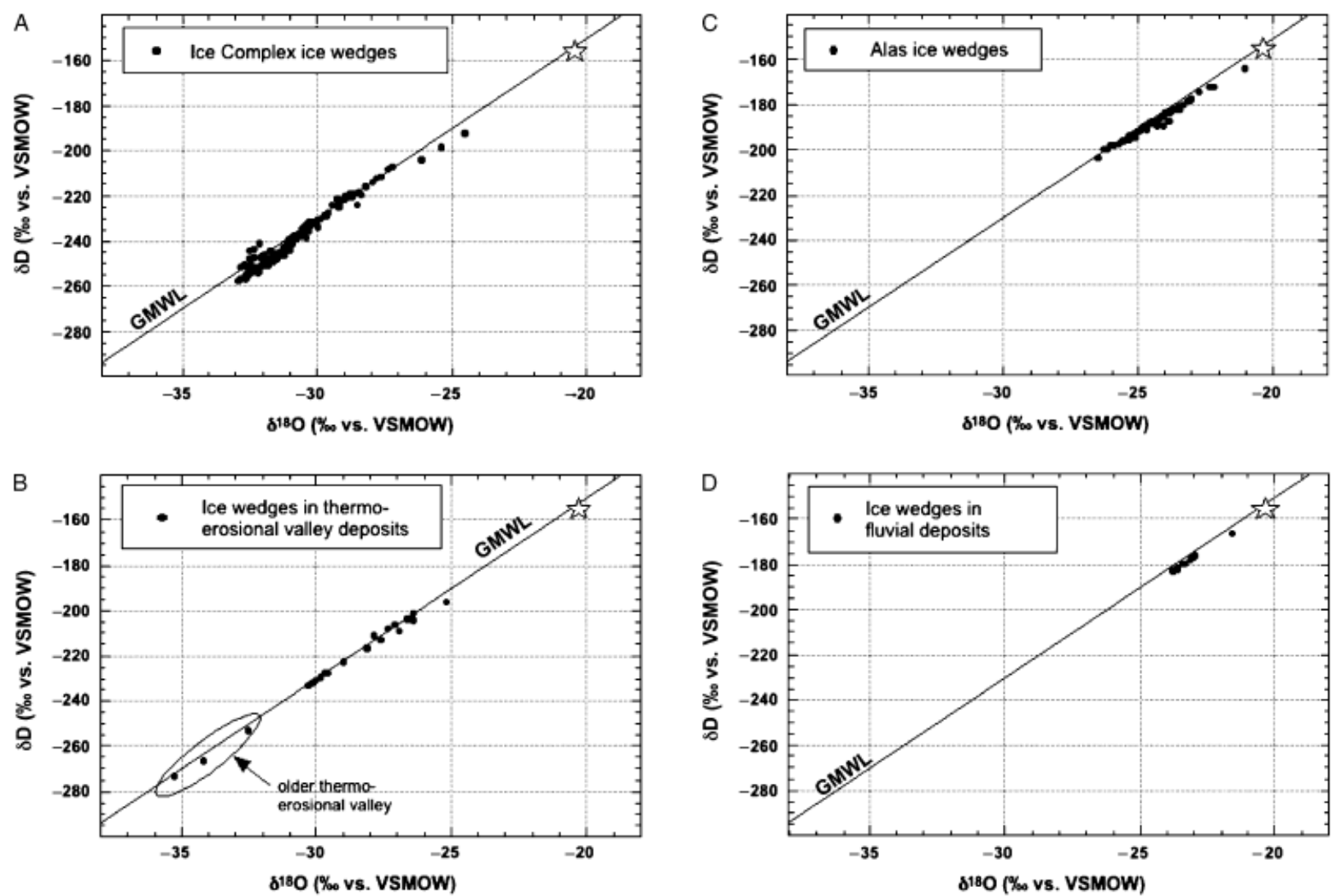

Fig. 18. $\delta^{18} \mathrm{O}-\delta \mathrm{D}$ diagrams for ice wedges in geocryological units: A. Ice Complex (unit Va). B. Thermokarst depressions (alases, unit VI). C. Thermo-erosional valleys (unit VI). D. Fluvial deposits of Zimov'e River (unit VI). GMWL is the Global Meteoric Water Line. The asterisk shows the mean isotopic composition of recent ice wedges sampled in 1999.
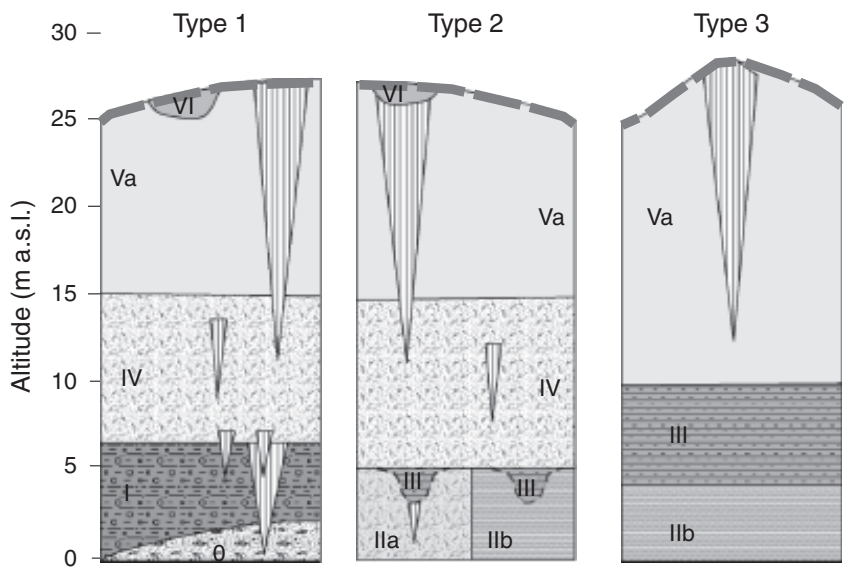

Type 4
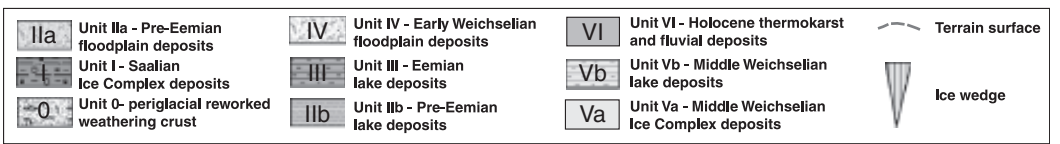

Fig. 19. Main types of stratigraphic relations at the studied coastal section of Bol'shoy Lyakhovsky Island.

from more southwest-situated sites near the Lena Delta (Pisaric et al. 2001; Grosse et al. 2007) are also characterized by a significant decrease of pollen concentration compared to the Allerød. Deposits from Kotelny Island accumulated just prior to $10 \mathrm{kyr}$ BP also reflect climate deterioration (Makeyev et al. 2003).
Numerous benthic diatoms in the sediment dated c. $11{ }^{14} \mathrm{C}$ kyr BP point to shallower water conditions. Rhizopod species diversity and abundance are very low in Younger Dryas sediments. Two taxa, Centropyxis constricta v. minima and C. sylvatica v. minor, are especially indicative of unfavourable conditions. 
Hence, a typical arctic environment existed in the region during the Younger Dryas. However, pollen records ${ }^{14} \mathrm{C}$ dated to $10.54 \pm 0.17$ and $10.08 \pm 0.21 \mathrm{kyr}$ BP from the northern part of the island reflect the dominance of shrub alder and dwarf birch communities in the Levaya Kutta River valley (Ukraintseva et al. 1989). Such a difference in similar dated records may reflect that different palaeoenvironments existed in well-protected valleys. Alternatively, and more likely, the bulk ${ }^{14} \mathrm{C}$ samples from the Kutta River might contain reworked organics, resulting in older ages for early Holocene sediments. Such age inversions are fairly common for Lateglacial and early Holocene sediments (Andreev et al. 2002a, b, 2003).

There are numerous dates from early Holocene sediments (sections R33, Lya97, L17 and L21+50). Their spectra are dominated by Alnus fruticosa, Betula, Poaceae and Cyperaceae pollen. The presence of Salix and Ericales and higher pollen concentration is also notable. Similar spectra are mentioned for the $8.8 \mathrm{kyr}$ BP old alas sediments studied by Igarashi et al. (1995) and undated alas sediments studied by Pirumova \& Rybakova (1984). Birch-, alder- and Ericales-dominated pollen spectra dated between 9 and $7 \mathrm{kyr}$ BP are numerous in northern and arctic Yakutia (Pisaric et al. 2001; Andreev et al. 2002a; Schirrmeister et al. 2002b, 2003; Makeyev et al. 2003 and references therein).

Thus, shrub associations dominated the area between c. 9 and $7.6{ }^{14} \mathrm{C}$ kyr BP. Pollen-based climate reconstruction inferred a temperature substantially warmer than present (Fig. 14). Precipitation was similar or slightly higher than present. After $7.6{ }^{14} \mathrm{C}$ kyr BP, shrubs gradually disappeared from the area and vegetation cover began to resemble that of modern tundra.

A very rich insect assemblage (tundra, steppe, shrubs, water and riparian species) found in the $c .8 \mathrm{kyr}$ BP old sediments reflects a mosaic landscape under warm climate. Although tundra taxa are dominant, typical tundra-steppe taxa (e.g. Morychus viridis) and taxa more common today in shrub tundra, foresttundra and/or even in taiga were found.

Rhizopods from all ecological groups are present in early Holocene sediments. Eurybiotic and soil taxa are dominant in 8.8 to $8.5 \mathrm{kyr} \mathrm{BP}{ }^{14} \mathrm{C}$-dated sediments; however, hydrophilic taxa point to a high water table and mesotrophic conditions. The sediments contain diatoms showing high species diversity and dominance of benthic taxa, but the lacustrine and bog species are also abundant. Eunotia valida, a taxon typical of boggy environment, dominates in sediments dated $c .8 .5 \mathrm{kyr}$ BP (no diatoms found in younger sediments). High species diversity of rhizopod communities in the c. $8.5-7.7{ }^{14} \mathrm{C}$ kyr BP old sediments points to a favourable soil environment. Hydrophilic and sphagnophilic taxa reflect high water table and more oligotrophic soil conditions. Rhizopod diversity is significantly lower in sediments accumulated after $c .7 .5{ }^{14} \mathrm{C}$ kyr BP, pointing to a deterioration of environment conditions.

The late-Holocene pollen spectra (R33 and L17 sections) ${ }^{14} \mathrm{C}$ dated to $3.7 \mathrm{kyr}$ BP reflect how herb tundra dominated the vegetation in the area. However, a fairly high content of Betula nana documents that dwarf birch grew on the island at least until $3.7 \mathrm{kyr}$ BP. Arctic and tundra mesophilous species living on the island nowadays dominate the insect assemblage. Thus, pollen and beetles indicate severe but a slightly warmer climate than today at $3.7 \mathrm{kyr}$ BP.

Relatively high winter temperatures during the last millennium are inferred from the stable isotopic composition of ice wedges. The warmest winter temperatures were derived from recent ice wedges (Fig. 18D).

\section{Bol'shoy Lyakhovsky Island palaeoenvironmental records in regional context}

The permafrost deposits from the Zimov'e key site on Bol'shoy Lyakhovsky Island (Andreev et al. 2004a, and this article) provide a unique palaeoenvironmental archive covering two glacial-interglacial cycles in this non-glaciated region between the west Eurasian and North American glaciation centres. Here, we synthesize the results of both these extensive studies in a wider context. In general, the studied deposits reveal a complex Quaternary stratigraphy that is strongly influenced by long-lasting accumulation periods during glacial episodes or stadials, as well as permafrost degradation during interglaciations.

Four typical stratigraphic sequences can be distinguished in the study area (Fig. 19) characterized by sharp erosive discordances and chronological gaps or by gradual transitions between individual stratigraphic units making the interpretation difficult. Our multiproxy studies reveal different periods and processes of the landscape history and reflect the importance of local-scale processes and events during periods of accumulation or erosion. This underlines the necessity to investigate large coastal outcrops rather than just a few single sections for a correct general interpretation.

The identified pre-Eemian cold period ( $>200$ to $130 \mathrm{kyr}$ ) correlates well with the Tazovsky stage in West Siberia (Astakhov 2004; Arkhipov et al. 2005) and the Eurasian Saalian stage. The local stratigraphy of this stage was subdivided into a stadial-interstadial alternation and is characterized by ice-rich deposits with thick syngenetic ice wedges (unit I) as well as loess-like floodplain and lake deposits (units IIa/b) (Andreev et al. 2004a). The Eurasian ice sheet reached its largest extension around $140 \mathrm{kyr}$ ago (Svendsen et al. 2004). The southern rim of Beringia was influenced by local mountain glaciers in the Verkhoyansk and Chersky Ranges and the Anadyr Highland (Glushkova \& 
Smirnov 2007; Stauch et al. 2007), although these glaciers never reached the lowlands in the North.

The following Eemian warming, correlating in Siberia with the Kazantsevo, resulted in thawing of icerich deposits and the formation of ice-wedge casts and thermokarst depressions filled with lacustrine deposits (unit III) containing numerous bioindicators. Pollenbased reconstructions show that summer temperatures were at least $4-5^{\circ} \mathrm{C}$ higher than today during the warmest time (Andreev et al. 2004a). However, plant macrofossils point to summer temperatures even $10^{\circ} \mathrm{C}$ higher (Kienast et al. 2008). The vegetation changed from open steppe-like associations at the beginning of the Eemian to shrub tundra during the optimum, and to tundra-like associations at the transition to the following glacial stage.

The Eemian marine transgression resulted in a global sea level about 5-6 $\mathrm{m}$ higher than that of today (Lambeck \& Chappell 2001). This transgression flooded the shelves of the Kara and Barents seas (Svendsen et al. 2004), but despite a higher sea level than present did not inundate the lowland plains of the Laptev Sea region. Kienast et al. (2008) conclude that only a post-Eemian neotectonic subsidence of several tens of metres, together with massive early Holocene thermokarst formation, could have led to the wide shelf inundation during the Holocene. Clear signs for the Eemian climate optimum are also evident in other Beringian regions, as indicated by widespread formation of icewedge casts, thermokarst lakes and peaty palaeosols, higher bioproductivity and the increased woody vegetation in northern latitudes (e.g. Glushkova \& Smirnov 2007; Lozhkin et al. 2007).

During the Early Weichselian, correlating with the Zyryan glaciation in the Verkhoyansk Mountains and the Ermakovo stage in West Siberia (Astakhov 2004; Arkhipov et al. 2005), loess-like floodplain accumulation (unit IV), shallow water bodies and very sparse vegetation were characteristic features. In that period, two glacial advances (c. 100-80 and 60-50 kyr BP) formed large ice sheets in northern Eurasia west of the Laptev Sea (Svendsen et al. 2004). Polygenetic ice-rich permafrost deposits accumulated in the west Beringian lowlands of NE Siberia, while the surrounding mountains were locally glaciated (Fradkina et al. 2005a, b; Stauch et al. 2007). After these Early Weichselian glacial stages, a relatively moderate environment characterized by strong seasonal differences developed during the Middle Weichselian, as indicated by the palaeoecological and geochronological data. During this time, the cryolithologically rather uniform deposition of the Ice Complex (unit Va), occurred at the study site and at many other regions of Siberian Beringia (e.g. Sher et al. 1997, 2005; Schirrmeister et al. 2002b, 2003). Freshwater diatom valves and hydrophilic rhizopod taxa found in the Ice Complex sediments confirm that water bodies existed during the late Pleistocene. How- ever, relatively high contents of soil diatom taxa show that such small basins or low centre polygonal ponds periodically dried up.

Scientific discussion of the stratigraphic significance of this rather moderate period in Siberia has been long. According to Sher et al. (2005), the traditional view of a Karginsky Interglacial should be considered invalid for northeast Siberia. However, our environmental records from Bol'shoy Lyakhovsky Island ${ }^{14} \mathrm{C}$ dated between $c .50$ and $25 \mathrm{kyr}$ BP distinctly indicate climate amelioration between two severe periods. Similar indicators are also evident for numerous other sites in the Laptev Sea region (Andreev et al. 2002a; Schirrmeister et al. 2002b, 2003; Kienast et al. 2005 and references therein). According to other palaeobotanical analyses (e.g. Anderson \& Lozhkin 2001), Beringia was more forested during this period, with maximal warmth occurring around $35-33{ }^{14} \mathrm{C}$ kyr BP (Elias 2001). All these records strengthen the concept of a Middle Weichselian Interstadial.

The accumulation of Late Weichselian (Sartan) deposits on the island is evident only by ${ }^{14} \mathrm{C}$-dated mammal bones, which were obviously relocated. Thermokarst processes during the Lateglacial/early Holocene transition most likely resulted in widespread erosion of the Late Weichselian deposits (Romanovskii et al. 2004; Grosse et al. 2007; Walter et al. 2007). The Late Weichselian was characterized by a new advance of the Eurasian and North American ice sheets, culminating in the Last Glacial Maximum (c. 21 kyr BP), although not reaching the Early Weichselian ice extent. Once more, Beringia was bordered by large ice sheets and large parts of the NE Siberian shelves were exposed, controlling regional climatic and environmental conditions. Owing to the sedimentary gap in the Bol'shoy Lyakhovsky record, no firm conclusion can be made for the local palaeoclimate. However, multiple palaeoenvironmental proxies from other sites in the Laptev Sea region indicate a very severe climate in NE Siberia during that period (e.g. Andreev et al. 2002a, 2003; Meyer et al. 2002a; Schirrmeister et al. 2002b, 2003; Kienast et al. 2005; Grosse et al. 2007 and references therein), in good agreement with other Beringian records (Sher 1997; Anderson \& Lozhkin 2001; Elias 2001; Fradkina et al. 2005a, b).

With postglacial decay of the ice sheets, the regional climatic conditions ameliorated. The marine transgression has significantly advanced on the NE Siberian shelves since about $15 \mathrm{kyr}$ BP (Bauch et al. 2001). In the study area, the early Holocene warming has resulted in widespread thermo-erosion and some lacustrine sedimentation in thermokarst basins (unit VI) since c. $12 \mathrm{kyr} \mathrm{BP}$, correlating with the widespread thermokarst development in other regions of the Laptev Sea region (Romanovskii et al. 2004). The early Holocene climate optimum on the island (c. 9-7.5 kyr BP) is in good accord with that of other multiple regional 


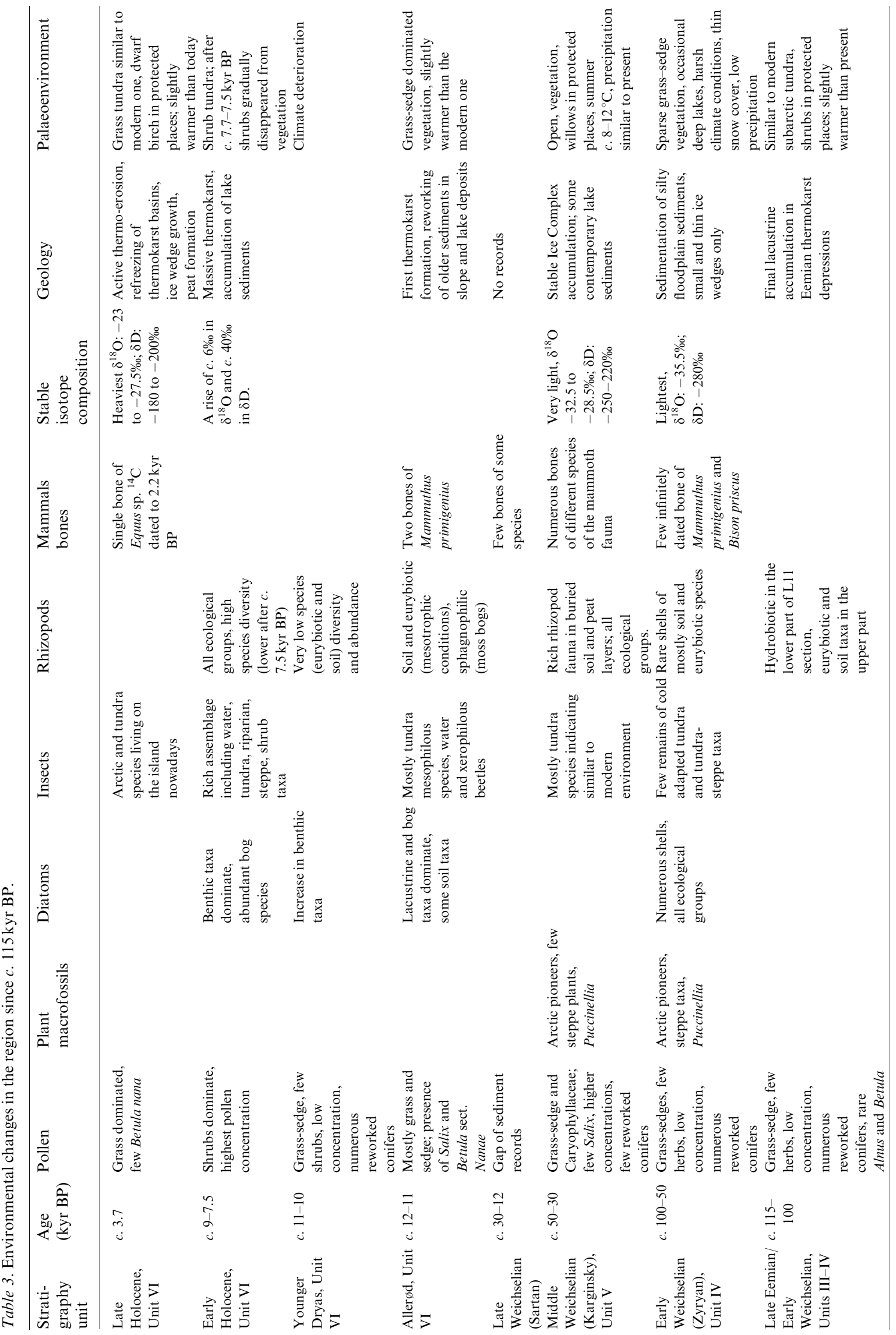


palaeoecological records in the Laptev Sea region (e.g. Andreev et al. 2002a, b, 2003, 2004a, b; Schirrmeister et al. 2002b, 2003; Bobrov et al. 2004 and references therein). Later environmental changes, e.g. the late Holocene climate deterioration, were strongly influenced by the ongoing postglacial transgression and the increase in marine climatic influences after Bol'shoy Lyakhovsky became an island around 6-7 kyr BP.

\section{Conclusions}

The palaeoenvironmental history of the Bol'shoy Lyakhovsky Island for the last $c .115 \mathrm{kyr}$ was reconstructed from permafrost sequences based on palaeo-ecological indicators (Table 3). The new data complete the results of our previous studies at this island covering the period between 200 and $115 \mathrm{kyr}$ BP (Andreev et al. 2004a) and greatly extend the environmental record of this region in providing a palaeoenvironmental archive for the past two glacial-interglacial cycles in western Beringia.

The environmental conditions of the late Pleistocene period are clearly related to major events in the adjacent regions of the northern hemisphere; namely, the dynamics of the glaciation centres in Northwest Siberia and North America. The general cooling trend during the Eemian/Early Weichselian transition results in a change from modern-like subarctic tundra conditions to a harsher climate with sparse vegetation in the Early Weichselian, correlating well with temporary maxima in the expansion of the Eurasian ice sheet around 90 and $60 \mathrm{kyr}$ ago. Stable isotope records from ground ice reflect the coldest winter temperatures of the studied period. Beginning with the Middle Weichselian, interstadial climate conditions result in formation of the characteristic ice-rich and fossil-rich Ice Complex deposits. Isotope and vegetation records indicate an increased continentality in this shelf region, with cold winters but warm summers. Herb-dominated vegetation prevailed, although dwarf willows grew in protected places, pointing to climate amelioration. This was also the most favourable period for the mammoth fauna. The climate became colder and drier again after c. $30 \mathrm{kyr}$ BP, correlating well with the new expansion of the Eurasian Ice Sheet climaxing in the Last Glacial Maximum. No Late Weichselian sediments were found, possibly reflecting active erosion processes during or most likely after that time. During the Lateglacial, correlating with the Allerød, herb and shrubby vegetation became dominant when July temperatures were $c .4{ }^{\circ} \mathrm{C}$ higher than those of today. Typical arctic environments prevailed during the following Younger Dryas, pointing to climate deterioration. Shrub alder and dwarf birch tundra became dominant between $c .9$ and $7.6 \mathrm{kyr}$ $\mathrm{BP}$, when summer temperatures were at least $4^{\circ} \mathrm{C}$ higher than those of present. After c. $7.6 \mathrm{kyr} \mathrm{BP}$, shrubs gradually disappeared and the vegetation cover began to resemble that of modern tundra. A strong rise in winter temperatures during the middle and late Holocene is evident by the heavier isotope signature of ice wedges, and clearly shows the decrease in seasonality and the growing marine influence due to southward directed Holocene transgression.

Based on our investigations, the study area is considered important for faunal and floral migration and a main refuge area in Eurasia during glacial stages. The reconstructed environmental changes correlate well with other regional and global climate fluctuations. Further investigation of the key sequences, including the application of new geochronological methods with larger age range and higher dating precision, will help to complete and extend the existing palaeoenvironmental data.

Acknowledgements. - We thank participants of the expedition 'Lena Delta 1999' for their generous help in collecting samples funded by the German Ministry of Science and Technology through the German-Russian science cooperation 'Laptev Sea System'. A. Andreev thanks the German Science Foundation (DFG) for supporting his studies (project SCHI 975/1-1); T. Kuznetsova the DFG for supporting his geological and mammal studies (grant 436 RUS 17/27/06); and S. Kuzmina the RFBR (project 01-04-48930) for supporting the insect studies. The comments of Professor P. L. Gibbard on the first version of the manuscript were greatly acknowledged. Special thanks are extended to Professor Mary Edwards for reviewing the English and for her scientific comments.

\section{References}

ACIA 2005: Arctic Climate Impact Assessment. 1042 pp. Cambridge University Press, Cambridge.

Anderson, P. M. \& Lozhkin, A. V. 2001: The Stage 3 interstadial complex (Karginskii/middle Wisconsinan interval) of Beringia: Variations in paleoenvironments and implications for paleoclimatic interpretations. Quaternary Science Reviews 20, 93-125.

Andreev, A. A., Forman, S. L., Ingólfsson, Ó. \& Manley, W. F. 2006: Middle Weichselian environments on western Yamal Peninsula, Kara Sea based on pollen records. Quaternary Research 65, 275-281.

Andreev, A. A., Grosse, G., Schirrmeister, L., Kuzmina, S. A., Novenko, E. Y., Bobrov, A. A., Tarasov, P. E., Kuznetsova, T. V., Krbetschek, M., Meyer, H. \& Kunitsky, V. V. 2004a: Late Saalian and Eemian palaeoenvironmental history of the Bol'shoy Lyakhovsky Island (Laptev Sea region, Arctic Siberia). Boreas 33, 319-348.

Andreev, A. A., Schirrmeister, L., Siegert, C., Bobrov, A. A., Demske, D., Seiffert, M. \& Hubberten, H.-W. 2002a: Paleoenvironmental changes in north-eastern Siberia during the Upper Quaternary - evidence from pollen records of the Bykovsky Peninsula. Polarforschung 70, 13-25.

Andreev, A. A., Siegert, C., Klimanov, V. A., Derevyagin, A. Y., Shilova, G. N. \& Melles, M. 2002b: Late Pleistocene and Holocene vegetation and climate changes in the Taymyr lowland, Northern Siberia reconstructed from pollen records. Quaternary Research 57, $138-150$.

Andreev, A., Tarasov, P., Schwamborn, G., Ilyashuk, B., Ilyashuk, E., Bobrov, A., Klimanov, V., Rachold, V. \& Hubberten, H.-W. 2004b: Holocene paleoenvironmental records from Nikolay Lake, Lena River Delta, Arctic Russia. Palaeogeography, Palaeoclimatology, Palaeoecology 209, 197-217.

Andreev, A. A., Tarasov, P. E., Siegert, C., Ebel, T., Klimanov, V. A., Melles, M., Bobrov, A. A., Dereviagin, A. Y., Lubinski, D. \& 
Hubberten, H.-W. 2003: Vegetation and climate changes on the northern Taymyr, Russia during the Upper Pleistocene and Holocene reconstructed from pollen records. Boreas 32, 484-505.

Arkhangelov, A. A., Mikhalev, D. V. \& Nikolaev, V. I. 1996: About early epochs of permafrost formation in northern Yakutia and age of ancient relicts of underground glaciation. In Velichko, A. A., Arkhangelov, A. A., Borisova, O. K., Gribchenko, Y. N., Drenova, A. N., Zelikson, E. M., Kurenkova, E. N., Mikhalev, D. V., Nikolaev, V. I., Novenko, E. Y. \& Timireva, S. A. (eds.): Razvitie oblasti mnnogoletnei merzloty i periglyatsial'noi zony Severnoi Evrazii i usloviya rasseleniya drevnego cheloveka, 102-109. Institute of Geography, Moscow.

Arkhipov, S. A., Volkova, V. S., Zolkina, V. S., Krutkover, A. A. \& Kul'kova, L. A. 2005: West Siberia. In Velichko, A. A. \& Nechaev, V. P. (eds.): Cenozoic Climatic and Environmental Changes in Russia, 105-120 Geological Society of America Special Paper 382.

Astakhov, V. 2001: The stratigraphic framework for the Upper Pleistocene of the glaciated Russian Arctic: Changing paradigms. Global and Planetary Change 31, 283-295.

Astakhov, V. 2004: Middle Pleistocene glaciations of the Russian North. Quaternary Science Reviews 23, 1285-1311.

Astakhov, V. 2006: Chronostratigraphic subdivisions of the Siberian Upper Pleistocene. Russian Geology and Geophysics 47, 1207-1220.

Bauch, H. A., Mueller-Lupp, T., Taldenkova, E., Spielhagen, R. F., Kassens, H., Grootes, P. M., Thiede, J., Heinemeier, J. \& Petryashov, V. V. 2001: Chronology of the Holocene transgression at North Siberian margin. Global and Planetary Change 31, 125-139.

Beyens, L. \& Chardez, D. 1997: New testate amoebae taxa from the Polar regions. Acta Protozoologica 36, 137-142.

Bobrov, A. A., Siegert, C., Andreev, A. A. \& Schirrmeister, L. 2004: Testate amoebae (Rhizopoda: Testacealobosea and Testaceafilosea) as bioindicators in the Late Quaternary deposits of the Bykovsky Peninsula, Laptev Sea, Russia. Palaeogeography, Palaeoclimatology, Palaeoecology 209, 69-84.

Bunge, A. A. 1887: Bericht über den ferneren Gang der Expedition. Reise nach den Neusibirischen Inseln. Aufenthalt auf der Grossen Ljachof-Insel. In Schrenk, L. V. \& Maximovicz, C. J. (eds.): Expedition zu den Neusibirischen Inseln und dem Jana-Lande (1885), 231-284. Beitraege zur Kenntnis des russischen Reiches und der angrenzenden Laender, Vol. III.

Chardez, D. 1965: Ecologie generale des Thecamoebiens (Rhizopoda, Testacea). Bulletin de l'Institut Agronomigue et des Stations de Recherches Gembloux 2, 306-341.

Chersky, I. D. 1891: The description of the collection of post-Tertiary mammals, collected by the New Siberian expedition in 1885-1886. Zapiski Imperatorskoi Akademii Nauk 65, 1-707 (in Russian).

Dereviagin, A. Y., Meyer, H., Chizhov, A. B., Hubberten, H.-W. \& Simonov, E. F. 2002: New data on the isotopic composition and evolution of modern ice wedges in the Laptev Sea Region. Polarforschung 70, 27-35.

Drachev, S. S., Savostin, L. A., Groshev, V. G. \& Bruni, I. E. 1998: Structure and geology of the continental shelf on the Laptev Sea, Eastern Russian Arctic. Tectonophysics 298, 357-393.

Elias, S. A. 2001: Beringian paleoecology. Results from the 1997 workshop. Quaternary Science Reviews 20, 7-13.

Fradkina, A. F., Alekseev, M. N., Andreev, A. A. \& Klimanov, V. A. 2005a: East Siberia. In Velichko, A. A. \& Nechaev, V. P. (eds.): Cenozoic climatic and environmental changes in Russia, 89-103. Geological Society of America Special Paper 382.

Fradkina, A. F., Grinenko, O. V., Laukhin, S. A., Nechaev, V. P., Andreev, A. A. \& Klimanov, V. A. 2005b: North-eastern Asia. In Velichko, A. A. \& Nechaev, V. P. (eds.): Cenozoic climatic and environmental changes in Russia, 105-120. Geological Society of America Special Paper 382.

Glushkova, O. Y. \& Smirnov, V. N. 2007: Pliocene to the Holocene geomorphic evolution and paleogeography of the El'gygytgyn Lake region, NE Russia. Journal of Paleolimnology 37, 37-47.

Grosse, G., Schirrmeister, L., Siegert, C., Kunitsky, V. V., Slagoda, E. A., Andreev, A. A. \& Derevyagin, A. Y. 2007: Geological and geomorphological evolution of a sedimentary periglacial landscape in Northeast Siberia during the Late Quaternary. Geomorphology $86,25-51$.
Guiot, J. 1990: Methodology of palaeoclimatic reconstruction from pollen in France. Palaeogeography, Palaeoclimatology, Palaeoecology $80,49-69$.

Hubberten, H.-W., Andreev, A., Astakhov, V. I., Demidov, I., Dowdeswell, J. A., Henriksen, M., Hjort, C., Houmark-Nielsen, M., Jakobsson, M., Kuzmina, S., Larsen, E., Lunkka, J. P., Lyså, A., Mangerud, J., Möller, P., Saarnisto, M., Schirrmeister, L., Sher, A. V., Siegert, C., Siegert, M. J. \& Svendsen, J. I. 2004: The periglacial climate and environment in northern Eurasia during the last glaciation. Quaternary Science Reviews 23, 1333-1357.

Igarashi, Y., Fukuda, M., Nagaoka, D. \& Saljo, K. 1995: Vegetation and climate during accumulating period of yedoma, inferred from pollen records. In Takahashi, K., Osawa, A. \& Kanazawa, Y. (eds.): Proceedings of the Third Symposium on the Joint Siberian Permafrost Studies between Japan and Russia in 1994, 139-146. Hokkaido University, Tsukuba.

Ilyashuk, B. P., Andreev, A. A., Bobrov, A. A., Tumskoy, V. E. \& Ilyashuk, E. A. 2006: Interglacial history of a palaeo-lake and regional environment: A multiproxy study of a permafrost deposit from Bol'shoy Lyakhovsky Island, Arctic Siberia. Journal of Paleolimnology 35, 855-872.

Kienast, F., Schirrmeister, L., Siegert, C. \& Tarasov, P. 2005: Palaeobotanical evidence for warm summers in the East Siberian Arctic during the last cold stage. Quaternary Research 63, 283-300.

Kienast, F., Schirrmeister, L., Tarasov, P., Grosse, G. \& Andreev, A. A. 2008: Continental climate in the East Siberian Arctic during the last interglacial: Implications from palaeobotanical records. Global and Planetary Change 60, 535-562.

Kiselyov, S. V. 1981: Late Cenozoic Coleoptera of North-East Siberia. 115 pp. Nauka, Moscow (in Russian).

Kunitsky, V. V. 1998: The Ice Complex and cryoplanation terraces of Bol'shoy Lyakhovsky Island. In Kamensky, R. M., Kunitsky, V. V., Olovin, B. A. \& Shepelev, V. V. (eds.): Problemy geokriologii, 60-72. Permafrost Institute, Yakutsk (in Russian).

Kunitsky, V. V., Schirrmeister, L., Grosse, G. \& Kienast, F. 2002: Snow patches in nival landscapes and their role for the Ice Complex formation in the Laptev Sea coastal lowlands. Polarforschung 70, 53-67.

Kuzmina, S. \& Sher, A. 2006: Some features of the Holocene insect faunas of north-eastern Siberia. Quaternary Science Reviews 25, $1790-1820$

Kuznetsova, T. V., Sulerzhitsky, L. D. \& Siegert, C. 2001: New data on the 'Mammoth' fauna of the Laptev shelf land (Arctic Siberia). Proceedings of the First International Congress 'The World of Elephants', 289-292. Rome.

Kuznetsova, T. V., Schirrmeister, L. \& Noskova, N. G. 2004: Collection of 'Mammoth' fauna from the Laptev Sea region in museums and institutes of Russian Academy of Science. Nauchno-prakticheskaya konferentsiya 'Problemy regional'noy geologii, muzeynyi rakurs', 45-50. Moscow (in Russian).

Lambeck, K. \& Chappell, J. 2001: Sea level change through the last Glacial cycle. Science 292, 679-686.

Lambeck, K., Purcell, A., Funder, S., Kjær, K. H., Larsen, E. \& Möller, P. 2006: Constraints on the Late Saalian to early Middle Weichselian ice sheet of Eurasia from field data and rebound modelling. Boreas 35, 539-575.

Lindroth, C. H. 1966: The ground-beetles (Carabidae, excl. Cicindelinae) of Canada and Alaska. Part 4. Opuscula Entomologica Supplementum 29, 409-648.

Lozhkin, A. V., Anderson, P. M., Matrosova, T. V. \& Minyuk, P. S. 2007: The pollen record from El'gygytgyn Lake: Implications for vegetation and climate histories of northern Chukotka since the late middle Pleistocene. Journal of Paleolimnology 37, 135-153.

Makeyev, V. M., Ponomareva, D. P., Pitulko, V. V., Chernova, G. M. \& Solovyeva, D. V. 2003: Vegetation and climate of the New Siberian Islands for the past 15,000 years. Arctic, Antarctic, and Alpine Research 35, 56-66.

Meyer, H., Dereviagin, A. Y., Siegert, C. \& Hubberten, H.-W. 2002a: Paleoclimate studies on Bykovsky Peninsula, North Siberia - Hydrogen and oxygen isotopes in ground ice. Polarforschung 70, 37-51. Meyer, H., Dereviagin, A. Y., Siegert, C., Schirrmeister, L. \& Hubberten, H.-W. 2002b: Paleoclimate reconstruction on Big Lyakhovsky Island, North Siberia - Hydrogen and oxygen isotopes in ice wedges. Permafrost and Periglacial Processes 13, 91-105. 
Nagaoka, D., Saljo, K. \& Fukuda, M. 1995: Sedimental environment of the Yedoma in high Arctic eastern Siberia. In Takahashi, K., Osawa, A. \& Kanazawa, Y. (eds.): Proceedings of the Third Symposium on the Joint Siberian Permafrost Studies between Japan and Russia, 8-13. Hokkaido University, Tsukuba.

Pirumova, L. G. 1968: Diatoms in Quaternary sediments of northern Yana-Indigirka lowland and Bol'shoy Lyakhovsky Island. In Zhuze, A. P. (ed.): Iskopaemye diatomovye vodorosli SSSR, 80-83. Nauka, Moscow (in Russian).

Pirumova, L. G. \& Rybakova, N. O. 1984: Main stages of the Late Cenozoic sedimentation in Northern Yakutia (according to data of spore-pollen and diatom analyses). In Korotkiy, A. N. (ed.): Paleogeograficheskie rubezhi $i$ metody ikh izucheniya, 63-81. DVNTs, Vladivostok (in Russian).

Pisaric, M. F. J., MacDonald, G. M., Velichko, A. A. \& Cwynar, L. C. 2001: The Lateglacial and Postglacial vegetation history of the northwestern limits of Beringia based on pollen, stomate and tree stump evidence. Quaternary Science Reviews 20, 235-245.

Romanovskii, N. N. 1958a: New data about Quaternary deposits structure on the Bol'shoy Lyakhovsky Island (Novosibirskie Islands) (In Russian). Nauchnye Doklady Vysshei Shkoly. Seriya geologo-geograficheskaya 2, 243-248.

Romanovskii, N. N. 1958b: Paleogeographic conditions of formation of the Quaternary deposits on Bol'shoy Lyakhovsky Island (Novosibirskie Islands) (In Russian). In Bogorov, V. G. (ed.): Voprosy fizicheskoi geografii polyarnykh stran. Vypysk I, 80-88. Moscow State University, Moscow.

Romanovskii, N. N. 1958c: Permafrost structures in Quaternary deposits (In Russian). Nauchnye Doklady Vysshei Shkoly. Seriya geologo-geograficheskaya 3, 185-189.

Romanovskii, N. N., Hubberten, H.-W., Gavrilov, A. V., Tumskoy, V. E. \& Kholodov, A. L. 2004: Permafrost of the east Siberian Arctic shelf and coastal lowlands. Quaternary Science Reviews 23, 1359-1369.

Schirrmeister, L., Kunitsky, V., Grosse, V., Meyer, H., Kuznetsova, T., Kuzmina, S., Tumskoy, V., Derevyagin, A., Akhmadeeva, I. \& Syromyatnikov, I. 2000: Quaternary deposits of Bol'shoy Lyakhovsky Island. Berichte zur Polarforschung 354, 113-168.

Schirrmeister, L., Kunitsky, V. V., Grosse, G., Schwamborn, G., Andreev, A. A., Meyer, H., Kuznetsova, T., Bobrov, A. \& Oezen, D. 2003: Late Quaternary history of the accumulation plain north of the Chekanovsky Ridge (Lena Delta, Russia) - a multidisciplinary approach. Polar Geography 27, 277-319.

Schirrmeister, L., Oezen, D. \& Geyh, M. A. 2002a: 230Th/U dating of frozen peat, Bol'shoy Lyakhovsky Island (North Siberia). Quaternary Research 57, 253-258.
Schirrmeister, L., Siegert, C., Kuznetsova, T., Kuzmina, S., Andreev, A. A., Kienast, F., Meyer, H. \& Bobrov, A. A. 2002b: Palaeoenvironmental and palaeoclimatic records from permafrost deposits in the Arctic region of Northern Siberia. Quaternary International 89, 97-118.

Schirrmeister, L., Siegert, C., Kunitsky, V. V., Sher, A., Grootes, P. \& Erlenkeuser, H. 2002c: Late Quaternary ice-rich permafrost sequences as an archive for the Laptev Sea Region paleoenvironment. International Journal of Earth Sciences 91, 154-167.

Sher, A. V. 1997: Yedoma as a store of paleoenvironmental records in Beringida. Beringian Paleoenvironments Workshop, 20-23 September, 140-144. Florissant, Colorado.

Sher, A. V., Kuzmina, S. A., Kuznetsova, T. V. \& Sulerzhitsky, L. D. 2005: New insights into the Weichselian environment and climate of the Eastern-Siberian Arctic, derived from fossil insects, plants, and mammals. Quaternary Science Reviews 24, 533-569.

Stauch, G., Lehmkuhl, F. \& Frechen, M. 2007: Luminescence chronology from the Verkhoyansk Mountains, north-eastern Siberia. Quaternary Geochronology 2, 255-259.

Stuiver, M., Reimer, P. J. \& Braziunas, T. F. 1998: High-precision radiocarbon age calibration for terrestrial and marine samples. Radiocarbon 40, 1127-1151.

Svendsen, J. I., Alexanderson, H., Astakhov, V. I., Demidov, I., Dowdeswell, J. A., Funder, S., Gataullin, V., Henriksen, M., Hjort, C., Houmark-Nielsen, M., Hubberten, H.-W., Ingólfsson, Ó., Jacobsson, M., Kjær, K., Larsen, E., Lokrantz, H., Lunkka, J. P., Lyså, A., Mangerud, J., Matioushkov, A., Murray, A., Möller, P., Niessen, F., Nikolskaya, O., Polyak, L., Saarnisto, M., Siegert, C., Siegert, M. J., Spielhagen, R. F. \& Stein, R. 2004: Late Quaternary ice sheet history of northern Eurasia. Quaternary Science Reviews 23, 1229-1272.

Tarasov, P., Granoszewski, W., Bezrukova, E., Brewer, S., Nita, M., Abzaeva, M. \& Oberhänsli, H. 2005: Quantitative reconstruction of the last interglacial vegetation and climate based on the pollen record from Lake Baikal, Russia. Climate Dynamics 25, 625-637.

Ukraintseva, V. V., Arslanov, K. A., Belorusova, Z. M. \& Ustinov, V. N. 1989: First data about early Holocene flora and vegetation of the Bol'shoy Lyakhovsky Island (New Siberian Archipelago). Botanichesky Zhurnal 74, 782-793 (in Russian).

von Toll, E. V. 1897: Fossil glaciers of New Siberian Islands and their relation to mammoth corpses and Glaciation Period. Zapiski Imperatorskogo Russkogo Geograficheskogo obshestva po obshei geografii 32, 1-137 (in Russian).

Walter, K. M., Edwards, M. E., Grosse, G., Zimov, S. A. \& Chapin III, F. S. 2007: Thermokarst lakes as a source of atmospheric CH4 during the last deglaciation. Science 318, 633-636. 


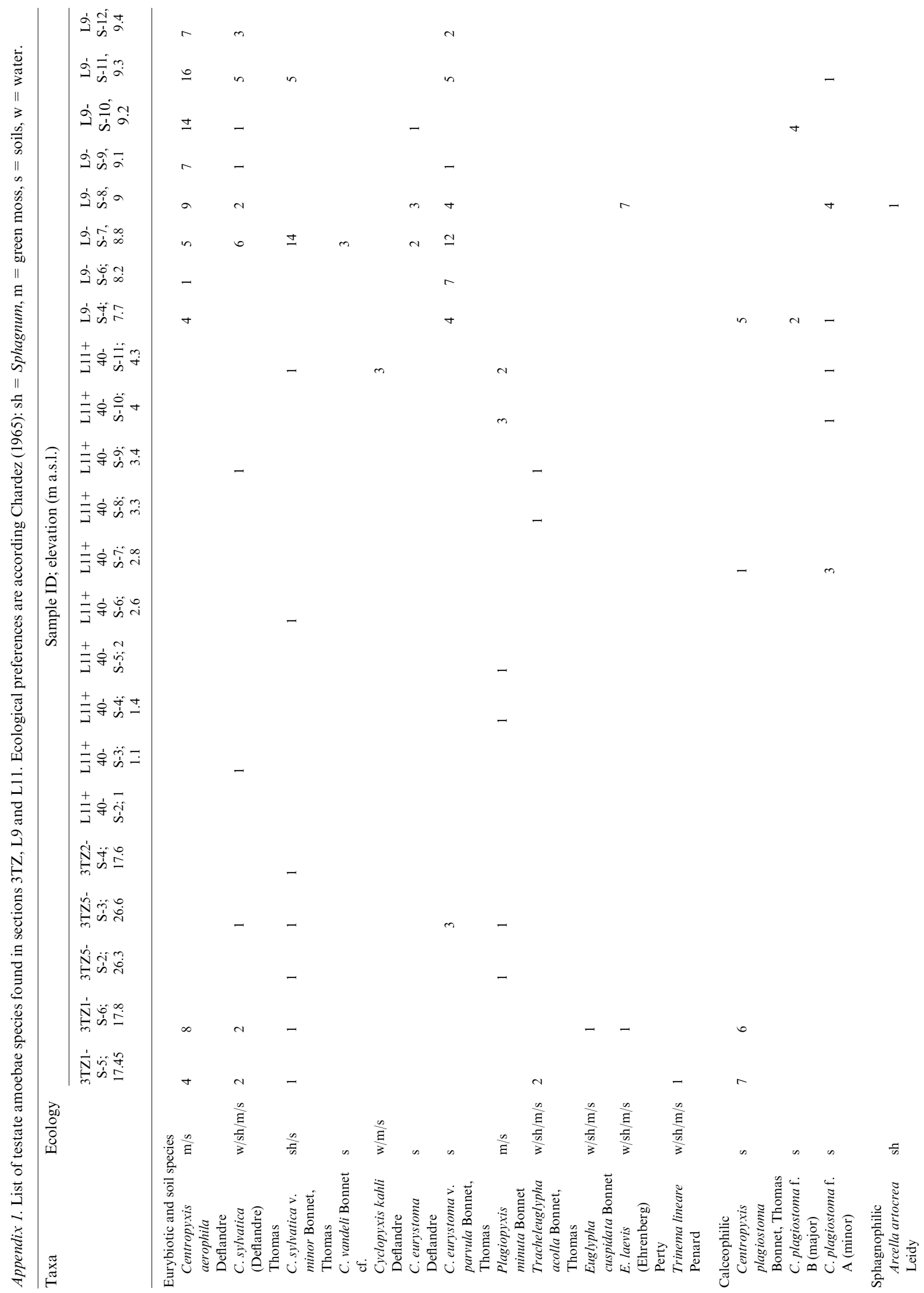




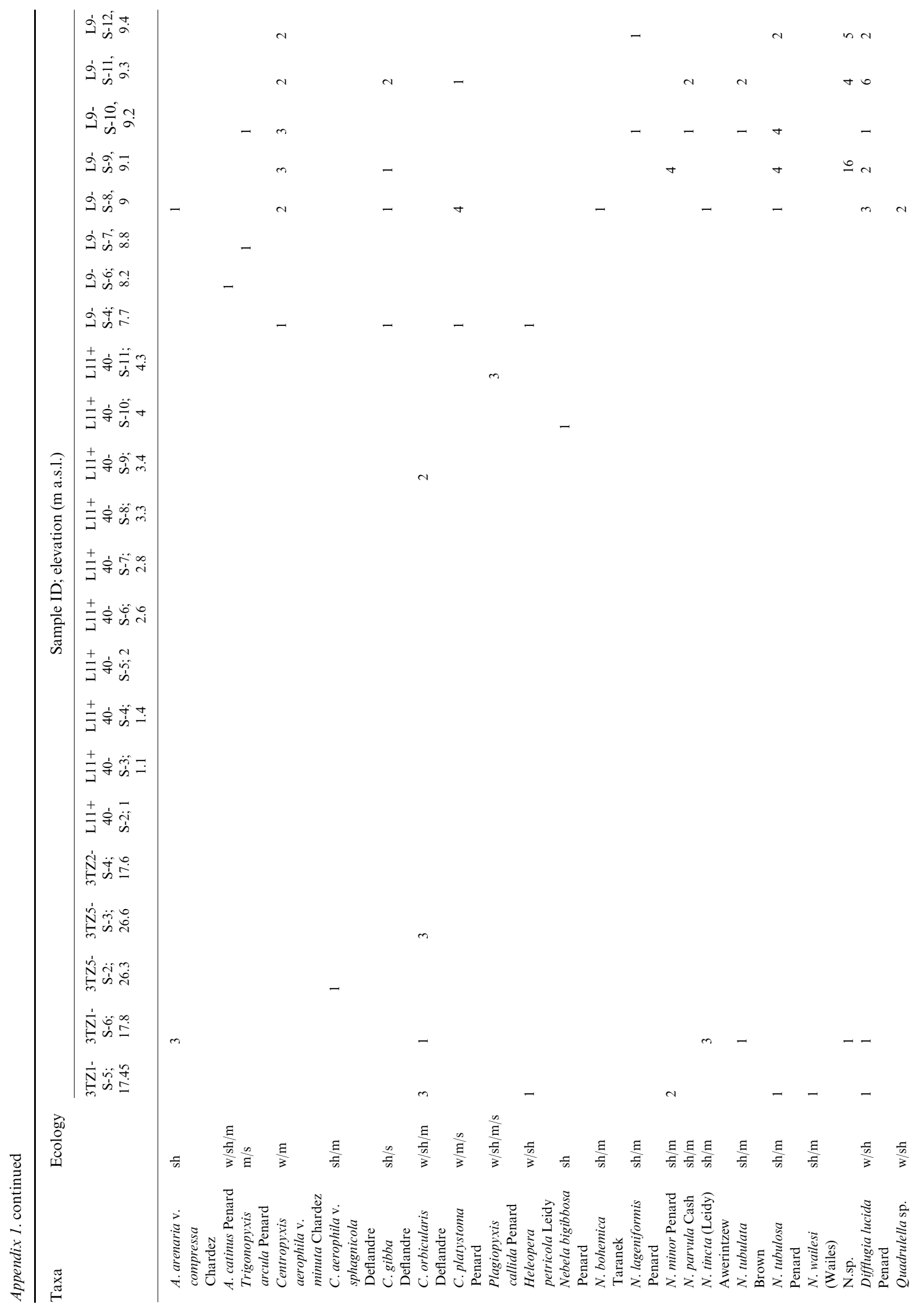




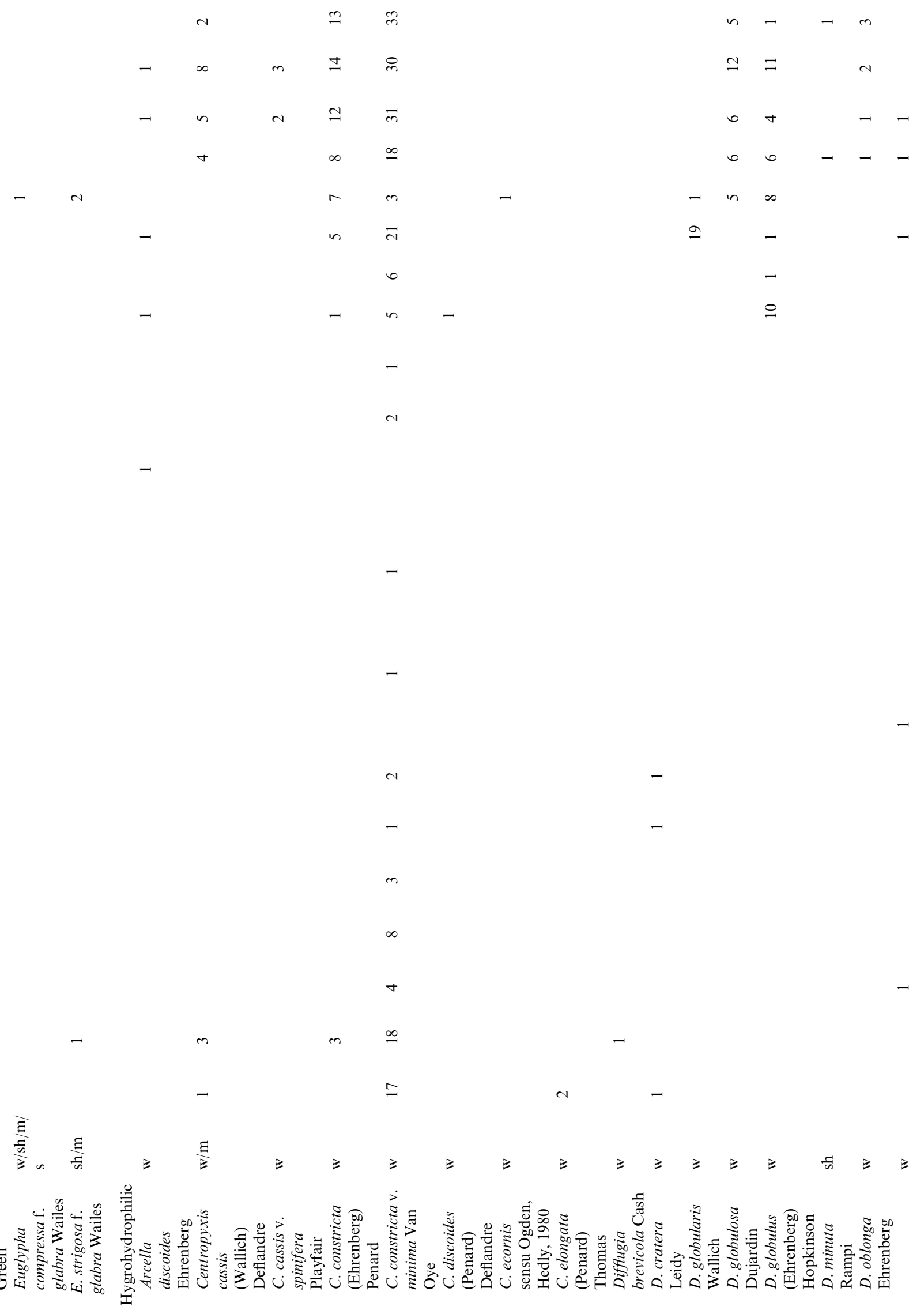



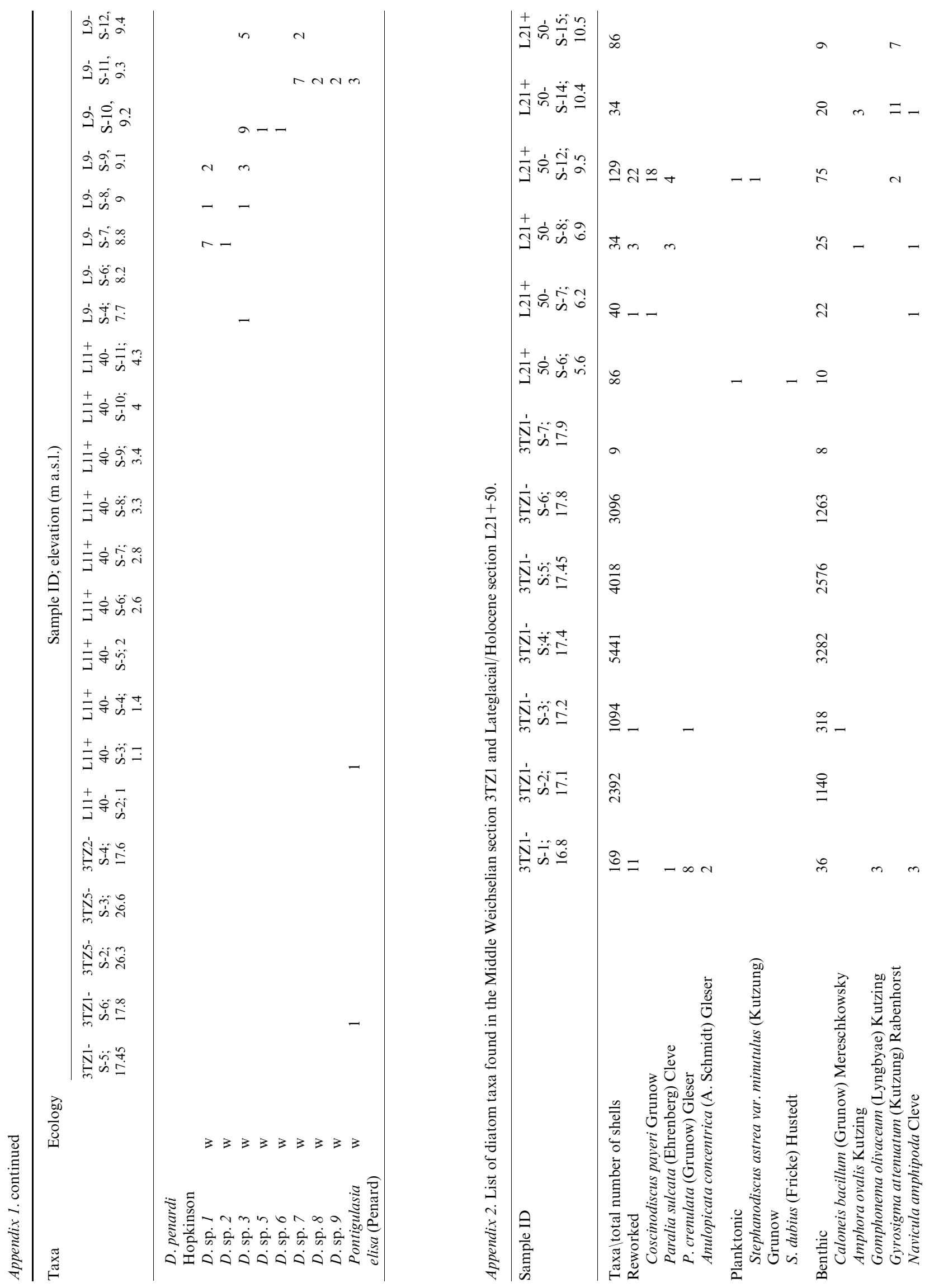


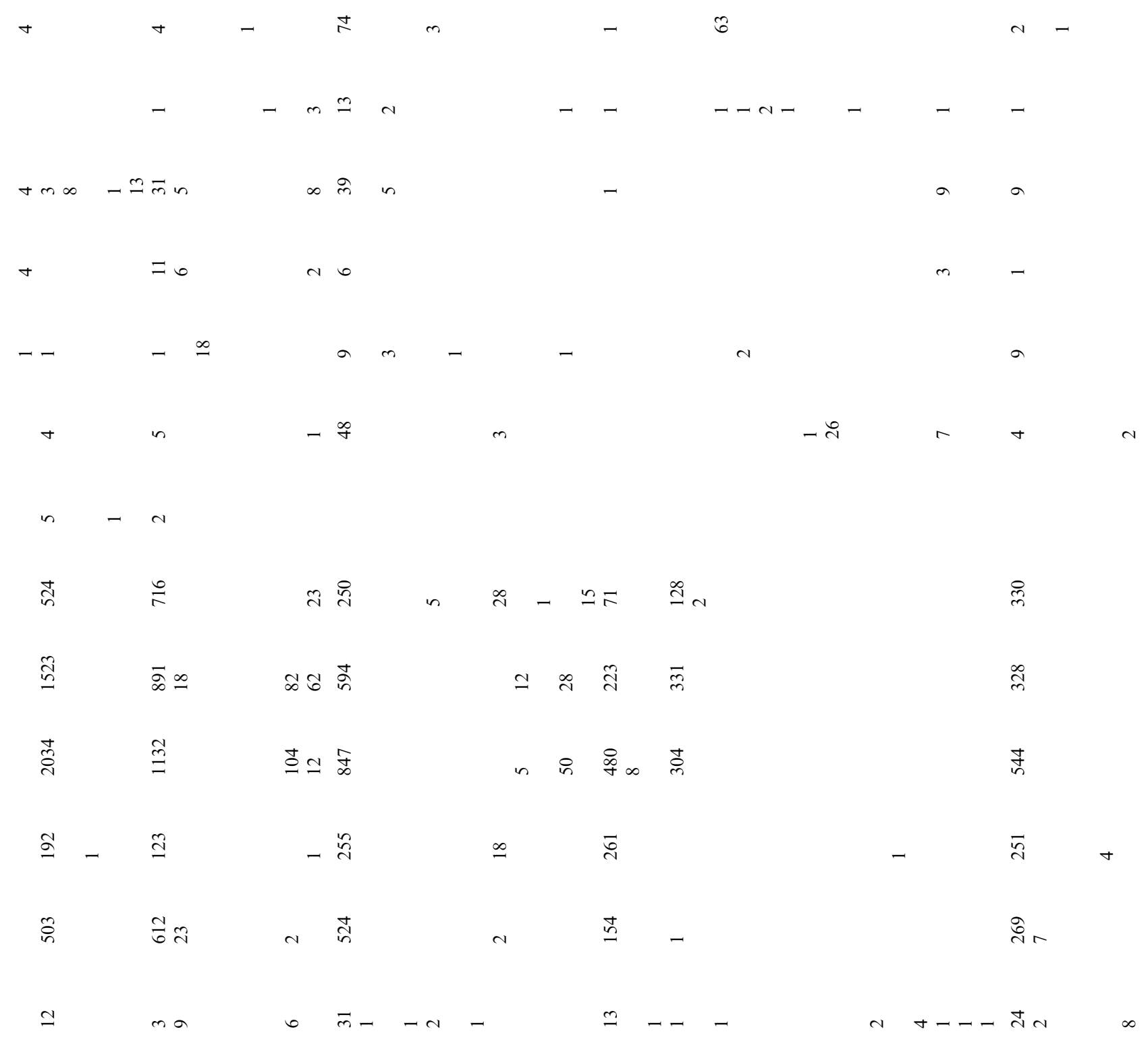

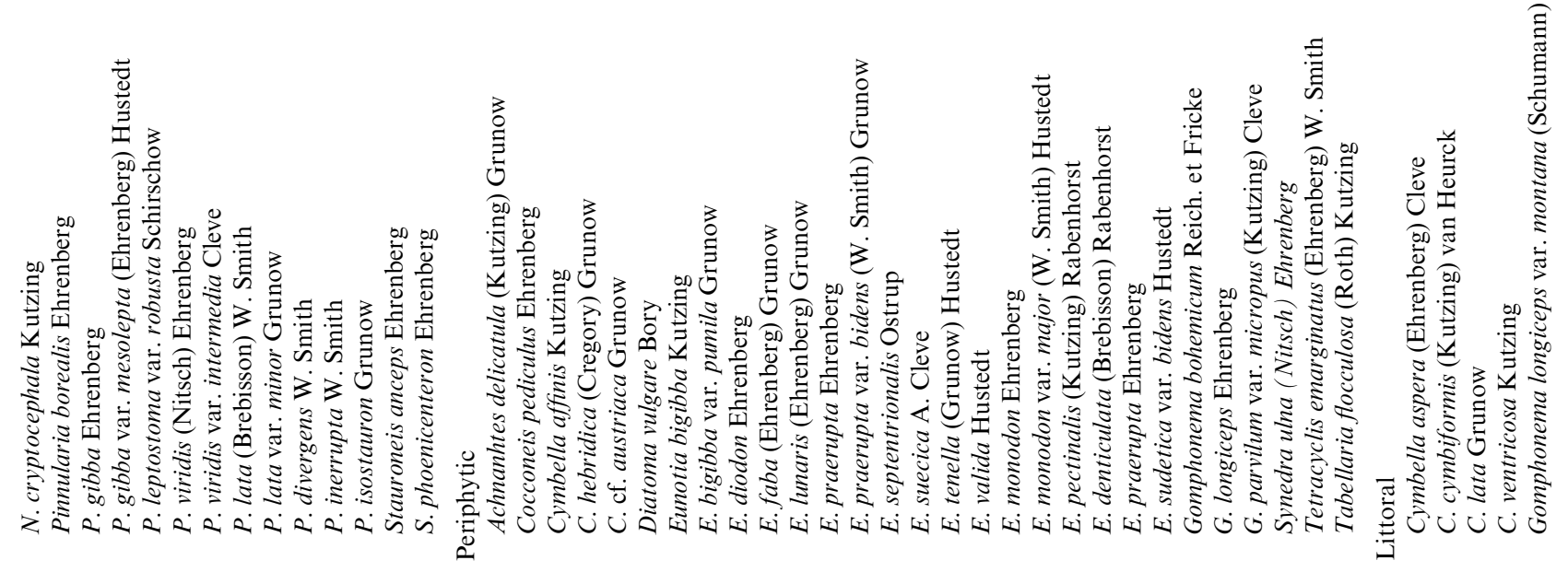



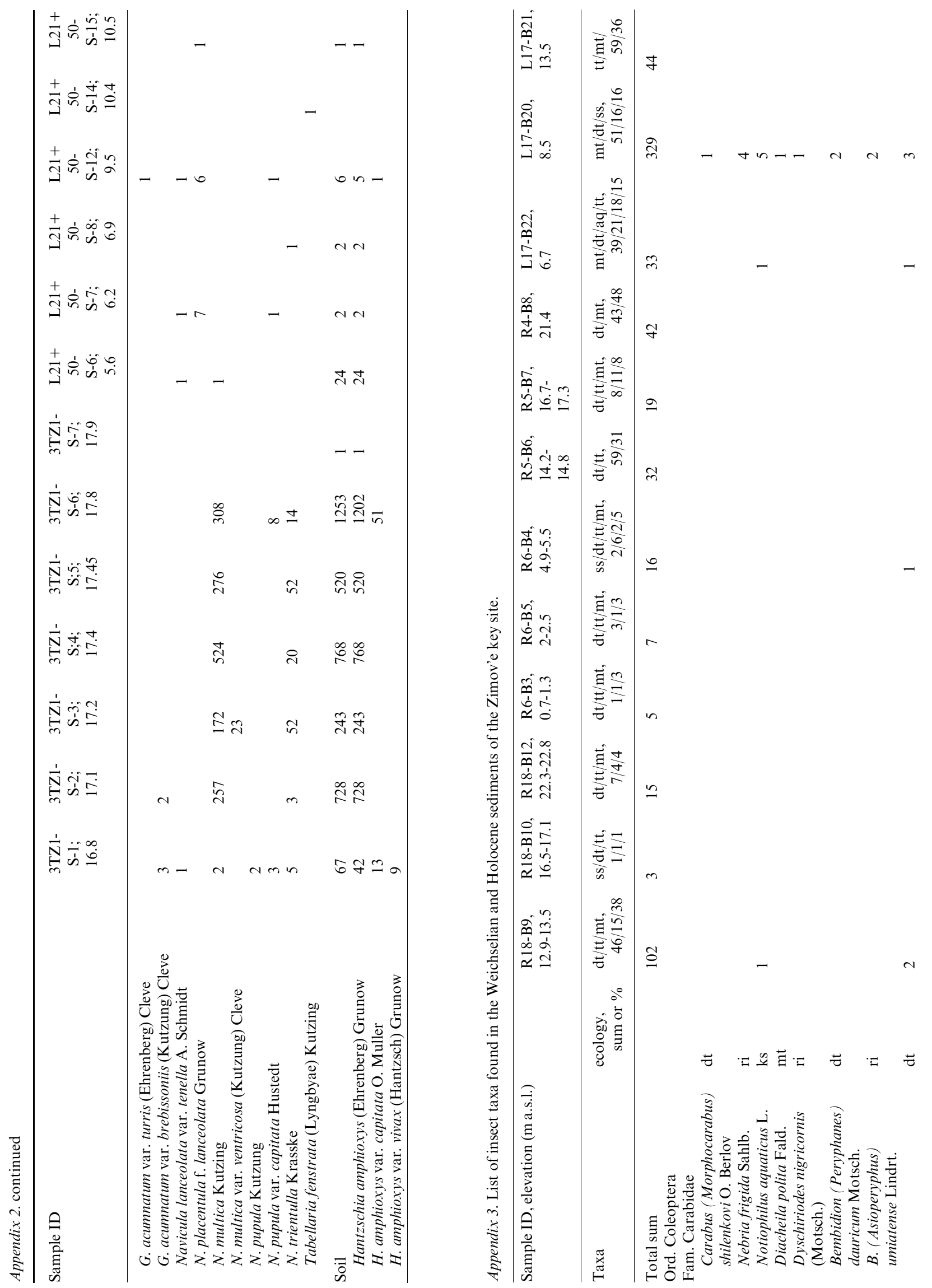


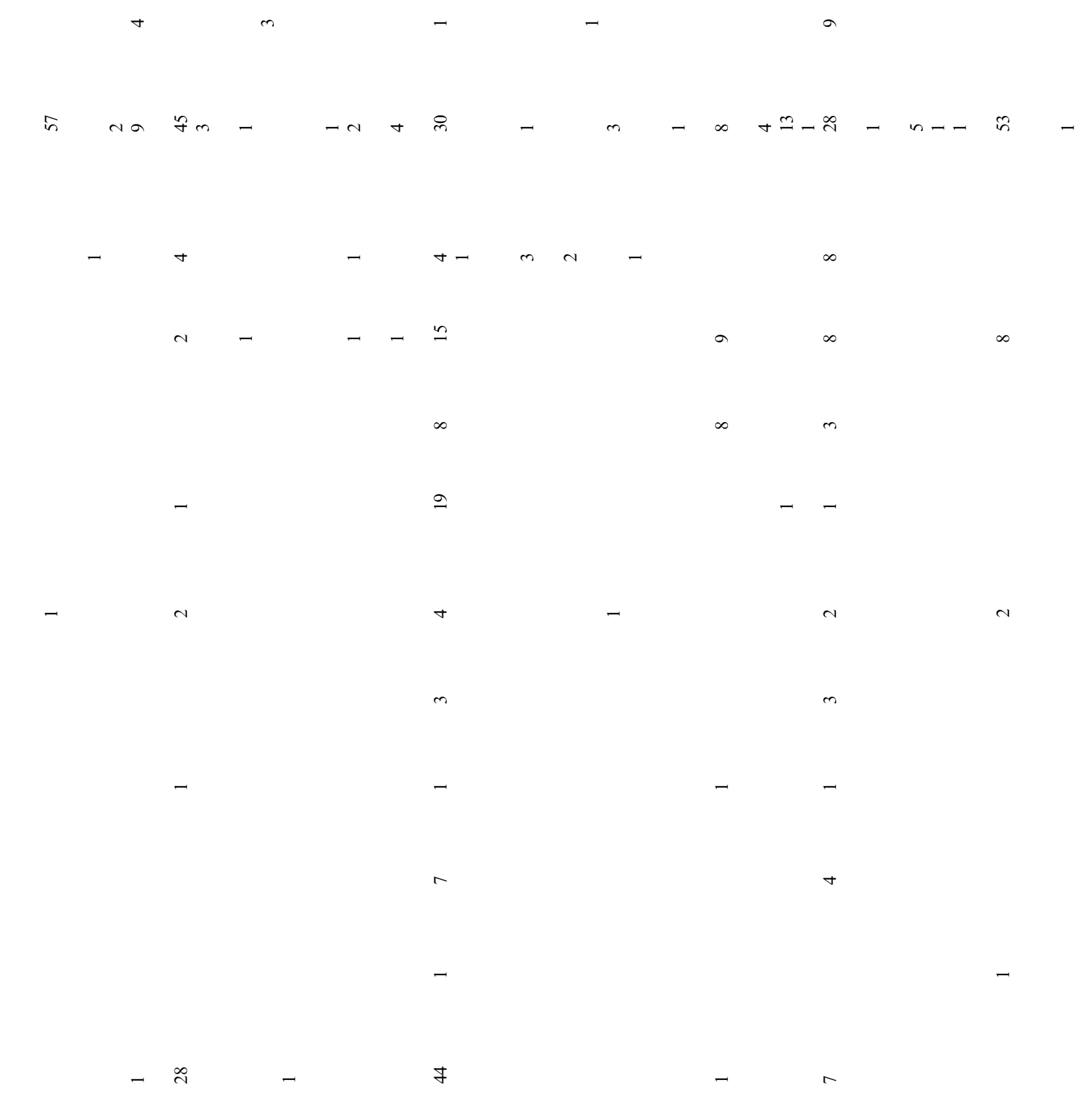

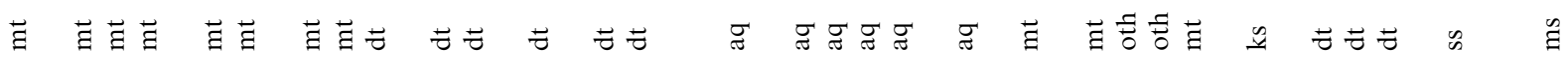

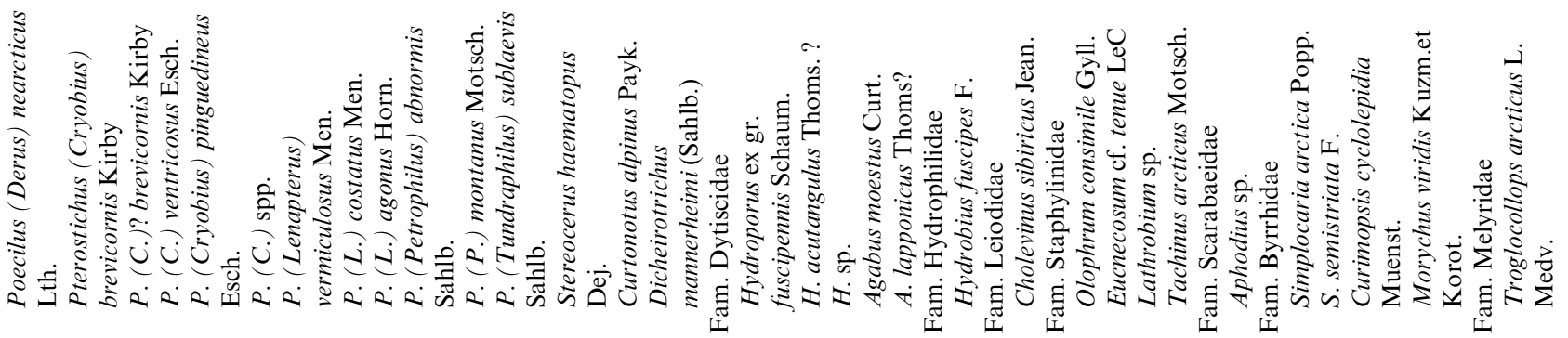




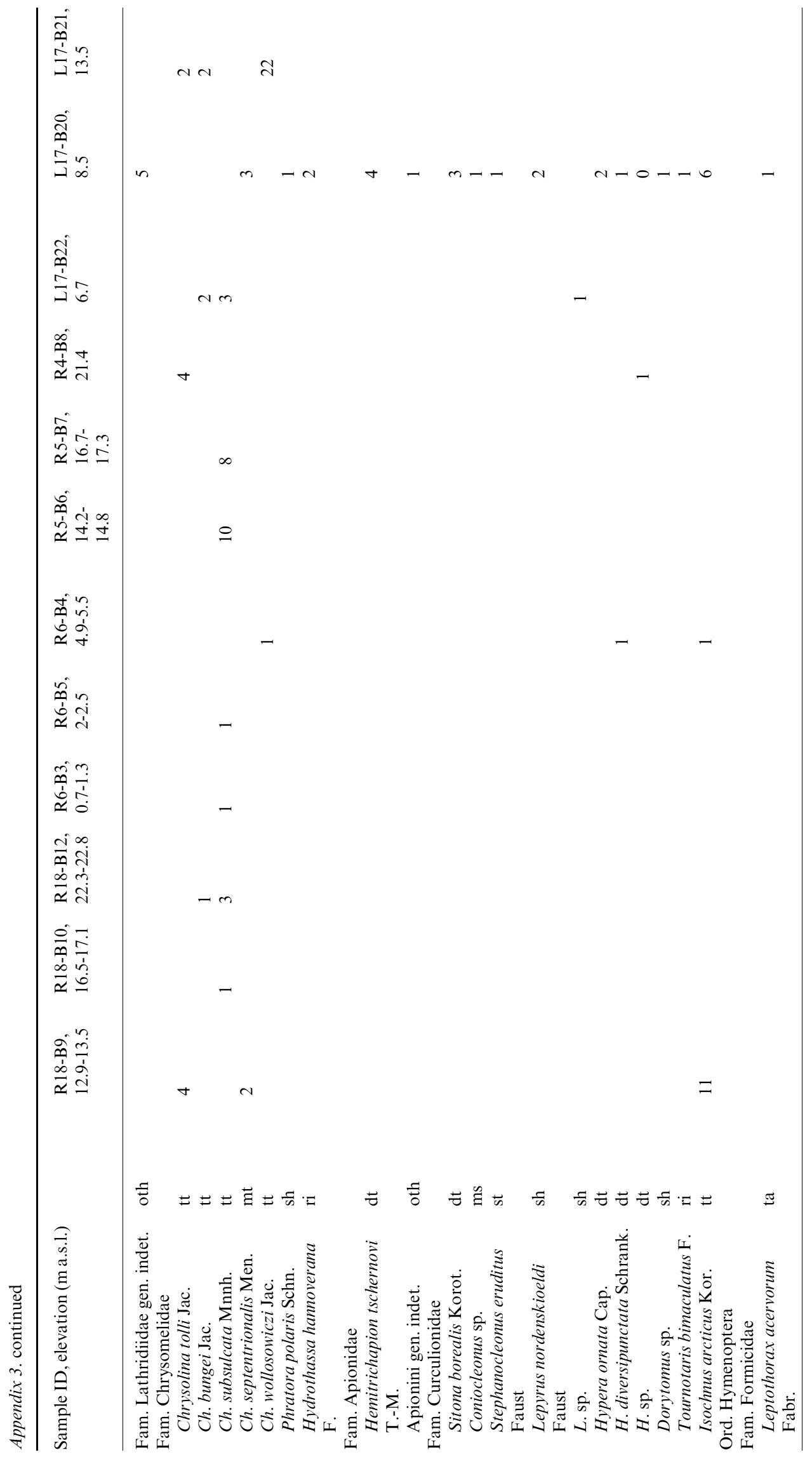


Appendix 4. List of identified vascular plant macrofossils with their abundance in the Early and Middle Weichselian samples and their classification into plant communities (syntaxa).

\begin{tabular}{|c|c|c|c|c|c|c|c|c|c|c|c|c|}
\hline Syntaxa & $\begin{array}{l}\begin{array}{l}\text { Sample ID, } \\
\text { elevation } \\
\text { (m a.s.l.) }\end{array} \\
\text { Taxa }\end{array}$ & 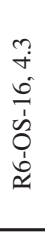 & 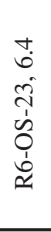 & 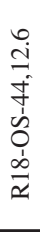 & 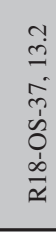 & 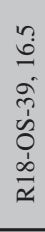 & 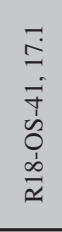 & 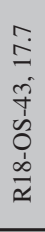 & $\begin{array}{l}\infty \\
\text { i } \\
\infty \\
0 \\
\dot{0} \\
0 \\
\infty \\
\infty \\
\end{array}$ & 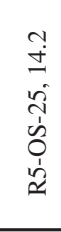 & 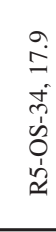 & 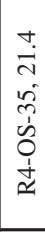 \\
\hline $\begin{array}{l}\text { Snow beds (Salicitea } \\
\text { herbaceae) }\end{array}$ & $\begin{array}{l}\text { Alopecurus sp. } \\
\text { Juncus biglumis } \\
\text { Salix } \mathrm{sp} . \\
\text { Androsace } \mathrm{c} \text { c. goro } \overline{d k o v i i} \\
\text { Cerastium beeringianum } \\
\text { Cochlearia arctica }\end{array}$ & - & $\begin{array}{l}1 \\
3 \\
-- \\
1\end{array}$ & - & $\begin{array}{r}1 \\
6 \\
-\end{array}$ & 8 & 3 & & 54 & $\begin{array}{c}5 \\
-- \\
4 \\
62\end{array}$ & 11 & - \\
\hline $\begin{array}{l}\text { Arctic pioneer vegetation } \\
\text { (Thlaspitea rotundifolii) }\end{array}$ & $\begin{array}{l}\text { Gastrolychnis involucrata } \\
\text { cf. Braya purpurascens } \\
\text { Draba } \text { sp. } \\
\text { Minuartia rubella } \\
\text { Papaver sect. Scapiflora } \\
\text { Potentilla hyparctica }\end{array}$ & $\begin{array}{c}2 \\
90 \\
11 \\
1\end{array}$ & 55 & 1 & $\begin{array}{c}223 \\
194 \\
26\end{array}$ & $\begin{array}{r}76 \\
6 \\
1\end{array}$ & $\begin{array}{c}119 \\
3 \\
2\end{array}$ & 6 & $\begin{array}{c}340 \\
2\end{array}$ & $\begin{array}{l}254 \\
622 \\
584\end{array}$ & $\begin{array}{c}177 \\
1 \\
54\end{array}$ & 9 \\
\hline $\begin{array}{l}\text { Dry tundra meadows } \\
\quad \text { (Kobresietea) } \\
\end{array}$ & $\begin{array}{l}\text { Minuartia arctica } \\
\text { Potentilla nivea } \\
\text { Kobresia bellardii } \\
\text { Selaginella rupestris } \\
\text { Ranunculus affinis/ } \\
\text { monophyllus } \\
-\overline{P o t e n t i l l a} \text { sp. } \\
\text { Artemisia } \mathrm{sp} \text {. }\end{array}$ & $\underline{3}$ & 1 & 1 & & & 1 & 1 & & -6 & & - \\
\hline $\begin{array}{l}\text { Steppe (Koelerio- } \\
\text { Corynephoretea, } \\
\text { Festuco-Brometea) }\end{array}$ & $\begin{array}{l}\text { Artemisia frigida } \\
\text { cf. Campanula rotundifolia } \\
\text { Androsace septentrionalis } \\
\text { Festuca } \mathrm{sp} . \\
\text { cf. Koeleria } \mathrm{sp} . \\
\text { Potentilla arenosa } \\
\text { Potentilla stipularis } \\
\text { Rumex acetosella } \mathrm{s} .1 . \\
\text { Veronica incana } \\
\text { Elytrigia/Elymus } \mathrm{sp} .\end{array}$ & $\begin{array}{c}90 \\
2 \\
40 \\
9\end{array}$ & & & $\begin{array}{c}232 \\
1\end{array}$ & 7 & $\begin{array}{l}2 \\
5\end{array}$ & 2 & 224 & 10 & & \\
\hline $\begin{array}{l}\text { Floodplain meadows } \\
\text { (Juncetea maritimii) }\end{array}$ & $\begin{array}{l}\text { Poa sp. } \\
\overline{\text { Allium }}-\overline{\text { schoenoprasum }} \\
\text { Puccinellia } \mathrm{sp.}\end{array}$ & 66 & $\begin{array}{c}23 \\
1 \\
29\end{array}$ & 6 & -2 & 1. & 63 & 6 & 14 & 17 & -5 & - \\
\hline \multirow[t]{2}{*}{$\begin{array}{l}\text { Halophytic pioneers at moist } \\
\text { shore sites (Bidentetea) }\end{array}$} & $\begin{array}{l}\text { Monolepis asiatica } \\
\text { Descurainia sophioides }\end{array}$ & 1 & & $\begin{array}{l}2 \\
1\end{array}$ & & & & & & & & \\
\hline & $\begin{array}{l}\text { Poaceae indet. } \\
\text { Caryophyllaceae indet. } \\
\text { Ranunculus sp. }\end{array}$ & 96 & 11 & 1 & $\begin{array}{l}4 \\
1\end{array}$ & $\begin{array}{r}38 \\
5\end{array}$ & $\begin{array}{c}107 \\
1\end{array}$ & 2 & $\begin{array}{r}30 \\
18\end{array}$ & 5 & 48 & \\
\hline
\end{tabular}

